Fall 9-1-2020

\title{
Is Turkey backsliding on global competitiveness and democracy amid its EU bid in limbo?
}

John Taskinsoy

Cemil Kuzey

Murray State University, ckuzey@murraystate.edu

Follow this and additional works at: https://digitalcommons.murraystate.edu/faculty

Part of the Business Commons

\section{Recommended Citation}

Taskinsoy, John and Kuzey, Cemil, Is Turkey Backsliding on Global Competitiveness and Democracy Amid Its EU Bid in Limbo? (July 10, 2020). Available at SSRN: https://ssrn.com/abstract=3648210 or http://dx.doi.org/10.2139/ssrn.3648210

This Non-Peer Reviewed Publication is brought to you for free and open access by Murray State's Digital Commons. It has been accepted for inclusion in Faculty \& Staff Research and Creative Activity by an authorized administrator of Murray State's Digital Commons. For more information, please contact msu.digitalcommons@murraystate.edu. 
Is Turkey backsliding on global competitiveness and democracy amid its EU bid in limbo?*

\author{
John Taskinsoy a \\ Cemil Kuzey b
}

\begin{abstract}
Turks have been around for thousands of years, who have established many states and empires in the "land of Turks" referring to Anatolia (Asia Minor) and the Eastern Thrace. The life of Turks, previously in the Altai Mountains of western Mongolia, commenced in the interior of Asia Minor when Seljuqs defeated the Byzantines at Manzikert in 1071 (Malazgirt in Turkish), which also meant the start of Turkification of Asia Minor. After the six century long reign of the Ottoman Empire (1299-1922), Turks were introduced to democracy when Mustafa Kemal abolished the Ottoman Empire in November 1922 by overthrowing Sultan Mehmet VI Vahdettin and established Turkish Republic on October 29, 1923 (The Grand National Assembly elected Mustafa Kemal as President in 1923). After the death of Mustafa Kemal Atatürk (November 10, 1938), Turkey has constantly faced instabilityinflicting developments (i.e. coup d'état, coup by memorandum, failed coup attempts, lack of fiscal and structural reforms, political turmoil, ineffective coalition governments, social unrest, chronic deficits, and repeated economic, financial, and currency crises. Turkey's remarkable economic and democratic performance (6\% YoY GDP growth between 2002 and 2007) was halted by endogenous (increasingly dictatorial/authoritarian rule, dysfunctional politics, negative developments in the rule of law, human rights, basic fundamentals, and the Judiciary/legal system) and exogenous factors (the 2008 global financial crisis originated in the U.S.; Cyprus' veto chapter 15 of Turkey's EU accession negotiations; prosecution, conviction, and sentencing of the U.S. pastor Andrew Brunson of terrorism charges for taking part in the 2016 failed coup attempt; Turkey's purchase of Russian S- 400 defense system; Turkey's removal from the F-35 program; the U.S. imposed sanctions/tariffs on steel imports from Turkey; repeated attacks on Turkish lira and the subsequent currency crisis).
\end{abstract}

Keywords: Global Competitiveness Index; EU Accession Negotiations; Turkey; Economic Growth JEL classification: I10, I18, J2, 031, G12, E42, C40, Q5, Q32, Q54, H23

\footnotetext{
* This research did not receive any specific grant from funding agencies in the public, commercial, or not-for-profit sectors. a Corresponding author Dr. John Taskinsoy, email address: johntaskinsoy@gmail.com Universiti Malaysia Sarawak (Unimas) - Faculty of Economics \& Business, 94300 Kota Samarahan, Sarawak, Malaysia.

b Associate Professor Cemil Kuzey, Murray State University - Department of Computer Science and Information Systems, ckuzey@murraystate.edu, Kentucky - USA.
} 


\subsection{Introduction}

Geopolitical risks and related diplomatic tensions were on the rise for Turkey prior to the 2008 global financial crisis (GFC). In December 2006, the EU suspended the opening of eight chapters on Customs Union and said that the negotiations would only resume if Turkey opened its ports (sea and air) to Greek-Cypriot traffic. Turkey-Cyprus relations became severely strained when France ${ }^{1}$ and Cyprus have unilaterally blocked other chapters, and in December 2009, Cyprus vetoed chapter 15 related to energy. ${ }^{2}$ Previously, the Turkish Prime Minister Recep Tayyip Erdoğan had been highly praised by the leaders of Muslim nations in the Middle East, Asia and Africa; however, international politics have changed quickly since the historic moment when Prime Minister Erdoğan walked off the stage at the 2009 Davos summit over clash in Gaza and accused Israeli ${ }^{3}$ President Shimon Peres and his country for engaging in inhumane treatment of Palestinians and killing their women and children.4

Turkey has been a devoted client of the International Monetary Fund (IMF) since March 1947, but the first standby agreement was signed in January 1961 subsequent the 1960 military coup (Ismihan et al., 2005). After a total of 19 standby agreements, President Erdoğan feels that Turkey has graduated from the IMF when his government paid off the entirety of its debt to the IMF in 2013. In various speeches, Erdoğan has often stated publicly that "No IMF in Turkey's future" and "IMF chapter will not be reopened" (Eken \& Schadler, 2012), but this hardly reflects Turkey's severe financial problems and the ensuing gloomy economic situation. Economists, scholars, and industry participants contend that Turkey's divorce from the IMF can qualify as a graduation since the country is on the brink of an economic crisis (i.e. financial collapse), attributable to excessive private and household debt, a failed coup (July 15, 2016) by a fraction of the Turkish army, massive dollarization, rising unemployment, the August rout (2018), a spike in corporate defaults, and coronavirus pandemic. ${ }^{5}$ Erdogan put an end to the IMF debate by saying Turkey is "far from needing" a bailout package from the IMF.

\footnotetext{
${ }^{1}$ France taking part in the Cyprus matter angered Ankara because France is not even one of the three guarantors; Greece, Turkey and England. On the Cyprus island, there are currently two countries; the Republic of Cyprus was established in 1960 (EU member since 2004), and the Turkish Republic of Northern Cyprus (TRNC) which was established in 1983 after the Turkish military intervened on the island in 1974 to protect its citizens and the island is divided since then.

2 In 1959, Turkey applied to become a member of the then European Economic Community (EEC), and in 1963, Turkey was accepted to become an associate member. In 1987 (after Spain joined the ECC in 1986), Turkey applied for full membership and almost a decade later (in 1996), Turkey as the first non-EU country joined the Customs Union with the EU. However, at the 1997 Luxembourg summit, Turkey was not placed among the 10 countries to join the EU in May 2004 and 2 more in 2007. Although the EU decision on Turkey was reversed at the 1999 Helsinki summit, just before the 2007 date, the EU suspended opening new chapters and closing opened chapters until Turkey opened its ports to Greek-Cypriot traffic.

3 Ironically, Turkey was the first Muslim nation to recognize Israel as a sovereign state in 1949, but kept its distance due to Turkey's cultural ties with the Arab world; the 1956 Arab-Israeli war; Israel's declaration of Jerusalem as its capital in 1980; the Jenin refugee camp incident in April 2002; Iraq war in 2003; the attacking of Turkish-owned Mavi Marmara (May 31,2010 ) by Israeli navy commandos; and Turkey's gas exploration and drilling in the Mediterranean.

${ }^{4}$ For a longer perspective and detailed discussions on this topic and other related topics, interested readers are welcome to check out Taskinsoy $(2012 ; 2013 ; 2018 ; 2019 ; 2020)$.

5 Financial Times, https://www.ft.com/content/7c9d9851-58cf-4561-9e8e-24dca0e6866e
} 
Before the coronavirus pandemic and the Fed induced Great Panic, a massive financial tsunami hit the Turkish economy in August 2018, the most severe shock since Turkey's economic crisis in 2001 (i.e. prior to and during the crisis, Turkey received over $\$ 30$ billion of financial assistance from the IMF). Without the IMF loans, many are skeptic that Turkey will never fully recover from the lasting after-effects of the August rout, underpinned by strong dollarization (see Figure 1), mounting external debt (i.e. over $\$ 430$ billion at the end of 2019 , $\$ 169$ billion of that is in short-term), extremely low net reserves (i.e. less than $\$ 30$ billion in April 2020), and the unthinkable cost of the coronavirus crisis (up to $\$ 50$ billion); all of these factors (i.e. mounting geopolitical tensions, potential second or third wave of COVID-19 insurgence) make Turkish economy more crisis-prone. President Erdoğan says the IMF is 'not on our agenda', but people speculate that he will have to eventually renege on its pledge.

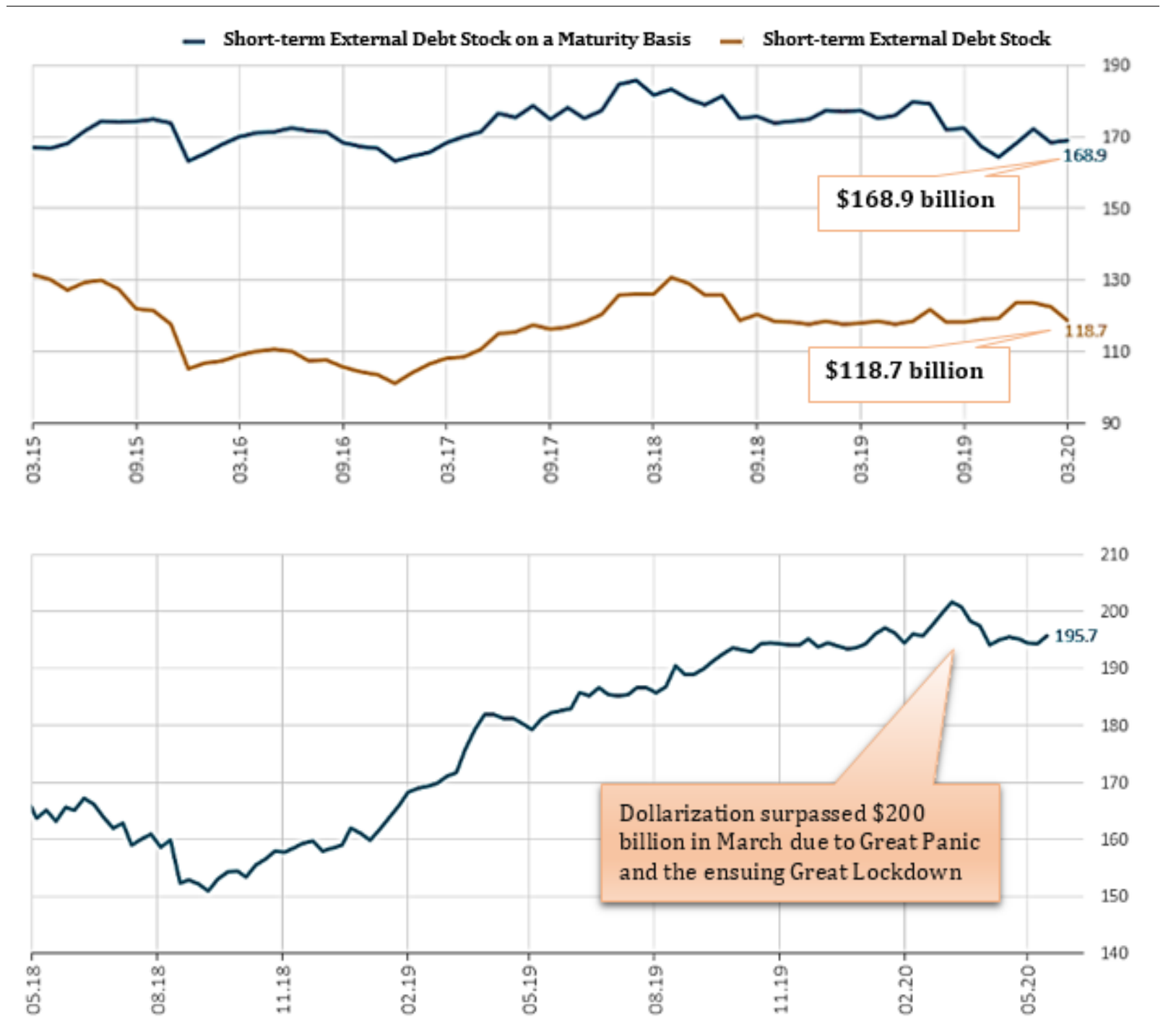

Source: Turkish central bank (TCMB); https://www.tcmb.gov.tr/wps/wcm/connect/en/tcmb+en

Figure 1: Turkey's short-term external debt and dollarization ( $\$$ billion) 


\section{$2.0 \quad$ Literature Review}

Along with the Greek and the Chinese, Turks ${ }^{6}$ have been around for at least four thousand years; first lived as nomadic people in Central Asia (i.e. Göktürk Empire united the nomadic Turkic tribes during 552-745), then established various states and empires when Turks (Seljuqs) defeated the Byzantines at Manzikert in 1071, opening the gates of Asia Minor (modern Turkey) to Turks during the medieval period (Jackson, 2002; Inalcik \& Quataert, 1995). The Seljuqs era ended by Mongols' repeated attacks (1243 onward); Osman I (the tribal leader) emerged as prince ("bey" in Turkish) when he took over an area in northwestern Anatolia (present Turkish city "Bursa") from the Byzantine, and founded the Ottoman Empire7 in 1299 (see Shaw \& Shaw, 1977; Kunt \& Woodhead, 1995; Kinross, 1977; Inalcik \& Quataert, 1995). The Ottoman Empire lasted 623 years (1299-1922); Istanbul's conquest in 1453 by Mehmed II - Mehmed the Conqueror (Turkish: Fatih Sultan Mehmet), changed history. During the reign of his grandson Suleiman I (1520-66) - Suleiman the Magnificent, the Ottoman Empire became the most powerful in the world ruling 25 million people from Hungary to Yemen; however with the Crimean War (1853-56), financially drained Empire entered the age of collapse and going into WWI on the side of Germany was a fatal decision that brought the Empire's inevitable demise (see Aksakal, 2008; Aksan, 2007; Barkey, 2008; Findley, 2004; Pamuk, 1987; Schaller \& Zimmerer, 2008).

The modern era of the Turkish history began in 1923 with the direction of one brilliant man, soldier, politician, strategist, and genius - Mustafa Kemal (Atatürk)8; at the time, there was only one university called Darülfünun ${ }^{9}$ inherited from the Ottoman Empire, no own bank (Birdal, 2010; Blaisdell, 1929) and no means of production of even the most basic things ${ }^{10}$ (Ahmad, 1993; Altug et al., 2008).

\footnotetext{
6 The name Turkey comes from the Latin word "Turchia" which translates to "land of the Turks".

7 The history of the Ottoman Empire is divided into four distinct periods; (1) the age of territorial expansion (1300 - 1481) and restoration (1402-1481); (2) the age of power at its peak (1481 - 1566); (3) the age of decline (1566 - 1807); and (4) the age of collapse and dissolution (1807 - 1922).

8 Atatürk (1981-1939), the greatest leader ever, introduced countless very important reforms to guide Turkey to become westernized. These reforms later became laws, which included: family name law; dress law (not using the traditional hat called fez, using modern Western type of hats); use of Turkish alphabet law (Latin alphabet); a law introduced new courts similar to those in Switzerland and Italy and closed down the existing Islamic courthouses. First time in Turkish history or the Ottoman history, Atatürk gave women unprecedented rights never seen before, and he said that "Humankind is made up of two sexes, women and men. Is it possible for humankind to grow by the improvement of only one part while the other part is ignored? Is it possible that if half of a mass is tied to earth with chains that the other half can soar into skies?"

9 In July of 1933, based on Professor Malche's findings, the Turkish Parliament abolished Darülfünun and created the Turkish Republic's first university called Istanbul University which also marked a special time in history that the word 'university' was actually used in the Turkish language for the first time.

10 The 1970s were especially hard times for the students in Turkey; political insatiability led to economic turmoil and created enormous violence due to constant clashes between members of the right-wing/left-wing and the armed forces (police and all branches of the military). In these challenging years, Turkey was divided into several political camps and students in higher education were heavily targeted and recruited to join these different political camps either by choice or by force. The tertiary education institutions throughout the country on a daily basis were under constant threat of attacks or bomb plots. As the unstoppable violence and social unrest kept rising, so did the death toll (estimated 5000 people were killed); the General Kenan Evren (the commander-in-chief), decided to take control and end the violence on September 12, 1980 which marked the third coup since the establishment of the Turkish Republic (1960, 1971, and 1980).
} 
Table 1: Ottoman foreign debt before OPDA 1854-77

\begin{tabular}{|c|c|c|c|c|c|c|c|c|}
\hline Year & $\begin{array}{c}\text { Debt Amount } \\
E\end{array}$ & $\begin{array}{c}\text { Issue Rate } \\
\%\end{array}$ & $\begin{array}{c}\text { Used } \\
\text { Amount } E\end{array}$ & $\begin{array}{c}\text { Used } \\
\text { Amount \% }\end{array}$ & $\begin{array}{l}\text { Nominal } \\
\text { Interest \% }\end{array}$ & $\begin{array}{l}\text { Effective } \\
\text { Interest \% }\end{array}$ & Allocated to & $\begin{array}{l}\text { Major investor } \\
\text { country }\end{array}$ \\
\hline 1854 & $3,000,000$ & 80.00 & $2,280,000$ & 76.00 & 6.0 & 7.9 & Crimean War & Britain \\
\hline 1855 & $5,000,000$ & 102.6 & $5,130,000$ & 102.00 & 4.0 & 3.9 & Crimean War & Britain \\
\hline 1858 & $5,000,000$ & 76.00 & $3,680,000$ & 74.00 & 6.0 & 8.1 & Support exchange rate & Britain \\
\hline 1860 & $2,000,000$ & 62.50 & $1,270,000$ & 62.00 & 6.0 & 9.6 & Budget deficit & France \\
\hline 1862 & $8,000,000$ & 68.00 & $5,440,000$ & 68.00 & 6.0 & 8.8 & Withdrawal of kaimes & Britain \\
\hline 1863 & $8,000,000$ & 71.00 & $5,680,000$ & 71.00 & 6.0 & 8.5 & Repayment of debt & France \\
\hline $1865 / 1$ & $6,000,000$ & 66.00 & $3,960,000$ & 66.00 & 6.0 & 9.1 & Repayment of debt and deficit & France \\
\hline $1865 / 2$ & $36,000,000$ & 50.00 & $18,180,000$ & 50.00 & 5.0 & 10.0 & Repayment of 1854 loan & France, Britain \\
\hline 1869 & $22,200,000$ & 54.00 & $12,000,000$ & 54.00 & 6.0 & 11.1 & Repayment of debt and deficit & France \\
\hline 1870 & $31,700,000$ & 32.13 & $10,180,000$ & 32.00 & 3.0 & 9.3 & Rumeli Railway & Austria, Germany, Italy \\
\hline 1871 & $5,700,000$ & 73.00 & $4,160,000$ & 73.00 & 6.0 & 8.2 & Budget deficit & Britain, France \\
\hline 1872 & $11,200,000$ & 98.50 & $9,460,000$ & 85.00 & 9.0 & 10.6 & Budget deficit & Britain, Austria, Germany \\
\hline $1873 / 1$ & $11,400,000$ & 55.00 & $6,300,000$ & 55.00 & 5.0 & 9.1 & Consolidation of 1872 bonds & France, Britain \\
\hline $1973 / 2$ & $27,800,000$ & 54.00 & $15,000,000$ & 54.00 & 6.0 & 11.1 & Budget deficit & France \\
\hline 1874 & $40,000,000$ & 43.50 & $17,400,000$ & 43.00 & 5.0 & 11.5 & Floating debt & France, Britain \\
\hline 1877 & $5,000,000$ & 52.00 & $2,600,000$ & 52.00 & 5.0 & 9.6 & Finance 1877 Russian War & France \\
\hline Total & $228,000,000$ & 64.89 & $122,720,000$ & 63.56 & 5.63 & 9.15 & \multicolumn{2}{|c|}{ Red color indicates figures are averaged } \\
\hline
\end{tabular}

Source: Birdal (2010); calculations by the author

Notes: In 1860, the Ottoman Empire tried to raise a loan of $£ 16,000,000$ at $14 \%$ interest rate through the underwriter French banker Jules Mirès, but this attempt failed because the French government did not allow it to be quoted in the French stock market; as a result, Mirès was not able to get enough investors to invest With the death of the Sultan Abdülmecid in 1861, the brother Sultan Abdülaziz as successor and his government was able to secure a fresh loan of $£ 8,000,000$ in 1862. Things were turning positive for a change, Sultan Abdülaziz's Imperial Ottoman Bank took advantage of the returned investors' confidence to broker two new loans; $£ 8,000,000$ at $6 \%$ (1863) and $£ 6,000,000$ at 6\%. The Ottoman Empire's indebtedness increased beyond control; during 1854-61, Sultan Abdülmecid agreed on loans totaling $£ 15,000,000$ (drawn $£ 12,360,000$ ). Sultan Abdülaziz, about the same time span as his brother (from 1862 to 1870), agreed on loans reaching $£ 112,000,000$.

In the first ten-year period (1854 to 1863), the Ottoman Empire barrowed from external sources a total of $£ 31,000,000$ (circa $£ 2,000,000$ of interest payment per annum); in the second eight-year period (1865 to 1872), with $£ 112,000,000$ the level of barrowing skyrocketed (i.e. five times more than the estimated $£ 22,000,000$ of annual revenues). The last spree of the Ottoman's barrowing before bankruptcy (1873 to 1877) climaxed, in just five years, the Empire secured loans stood at $£ 84,000,000$ (again four years' worth of tax and customs revenues were used to pay these massive loans). From 1865 to 1877 (13 years), the Ottoman Empire paid over $£ 20,000,000$ for interest expense. The Ottoman Empire was not able to survive under the heavy financial burden of the massive loans it contracted between 1854 and 1874; as a result, the Ottoman Empire financially collapsed (bankrupt) in October 1876. The war with Serbia and Montenegro in 1876 and with Russia in 1877 pulled plug on the Ottoman Empire; the ill man as Europeans called went into coma just prior to World War I (1914-18). Because the Ottoman Empire was not able to pay its outstanding external debt, creditors agreed to reduce the Ottoman's debt almost by 50\%, from $£ 228,000,000$ to $£ 128,000,000$ (see Eldem, 2005). 
The Ottoman Empire existed without a bank for over 600 years, foreign capital flowed via the Galata Bankers who were Greeks, Jews, and Armenians. Not only these bankers enjoyed $15 \%$ to $20 \%$ interest charged on short-term advances, but had extensive influence on Sultans; therefore, Europeans coined the term "Galata Vampires" since these bankers earned returns like sucking the blood of their clients (Birdal, 2010; Hulkiender, 2003; Kazgan, 1991). As illustrated in Table 1, these small types of banking operations were seen as utterly insufficient and inadequate to finance the Empire's ambitious efforts of modernization (Anderson, 1964; Blaisdell, 1929; Rodkey, 1930). In 1878 at the Congress of Berlin, France and Britain took control of the Ottoman debt which was halved through negotiations since the Empire was unable to pay even interest payments of the debt. Consequently, Sultan Abdülhamid II was forced to create the OPDA 11 in 1881 in order to administer war reparations and the Empire's outstanding foreign debt stock (Blaisdell, 1929; Guran, 2003; Kıray, 1995).

Table 2: Economic indicators of Turkey

\begin{tabular}{lrrrrrr}
\hline & 1880 & 1913 & 1929 & 1950 & 1980 & 2005 \\
\hline Population (million) & 13 & 17 & 14 & 21 & 45 & 69 \\
Share of urban population (\%) & 26 & 28 & 24 & 25 & 44 & 68 \\
Share of agriculture in labor (\%) & 80 & 80 & 85 & 84 & 51 & 34 \\
Share of agriculture in GDP (\%) & 54 & 55 & 42 & 54 & 26 & 11 \\
GDP per capita a (\$) & 850 & 1200 & 710 & 1620 & 4020 & 7500 \\
-as \% of W. Europe plus U.S. & 37 & 29 & 16 & 24 & 25 & 30 \\
-as \% of developing countries & 147 & 168 & --- & 188 & 219 & 225 \\
-as \% of world & 81 & 79 & --- & 77 & 89 & 117 \\
Life expectancy (years) & --- & 30 & --- & 48 & 62 & 69 \\
Literacy age 15+ (\%) & --- & 10 & --- & 32 & 69 & 89 \\
Periods & $1880-13$ & $1914-29$ & $1930-49$ & $1950-79$ & $1980-05$ & $2005-25$ \\
Annual population growth (\%) & 0.8 & -1.1 & 1.8 & 2.6 & 1.7 & 1.9 \\
Annual GDP per capita growth (\%) & 0.8 & 0.0 & 3.1 & 3.1 & 2.5 & 2.9 \\
\hline
\end{tabular}

Source: Altug et al. (2008); a PPP adjusted in 1990 \$USD

Mustafa Kemal Atatürk's Turkey started way behind in the race of global competitiveness ${ }^{12}$ (as shown in Table 2, no skilled labor force, low literacy and high mortality); at this background, he was unable to develop an autonomous economic strategy. The vestiges of the Ottoman Empire and the treaties signed in the post-WWI with harsh terms ${ }^{13}$ forced Turkey to accept the Ottoman Empire's outstanding debt at a reduced rate; as such, $62 \%$ of the pre-1912 debt and $77 \%$ of the post-1912 debt ${ }^{14}$ (Caillard,

\footnotetext{
11 OPDA (similar to the IMF) refers to the Ottoman Public Debt Administration.

12 Atatürk realized that any type of factory to produce goods had to build by the government due to lack of skilled labor, resources, and potential investors; therefore, any sort of production was done by state-owned enterprises.

13 The Armistice of Mudros (October 30,1918) was followed by the Treaty of Sèvres (August 10, 1920) which had the utmost objective of liquidating the Ottoman Empire and abolishing Turkish sovereignty, but it failed and was replaced by the Treaty of Lausanne (July 24, 1923); Turkey gave up Arab provinces, Cyprus, and Dodecanese, plus the Aegean Sea and the Black Sea were declared open to all shipping.

14 Turkey made its final debt payment on 25 May 1954.
} 
1885; Çakır, 2001; Conte, 2014; Eldem, 1994). Atatürk's ambition to develop an economic policy was interrupted by the Great Depression of the 1930s, but he still put together a five-year plan comprising many government-initiative projects (Keynes, 1936) ${ }^{15}$ such as building railroads, setting up factories, establishing higher education institutions, and creating a central bank (Ahmad, 1993; Findley, 2004; Mango, 2000; Kedourie, 1989; Nas, 1992; Zurcher, 2004; Webster, 1939).

Atatürk observed how the Ottoman Empire struggled financially because it had no national banks ${ }^{16}$; as a result, its economy was besieged by heavy borrowings from France and England that ultimately put a tight leash on sultans (Blaisdell, 1929; Birdal, 2010; Caillard, 1894; Eken \& Schadler, 2012; Önis, 2009; Eldem, 2005; Findley, 1986; Rustow, 1987). Even then, Atatürk knew it perfectly that Turkey's forward progress would be possible with the help of a national banking system not only capable of serving the young country's extensive and challenging financial needs, but enabling and fostering the development of crucial industries. For this exact reason, Atatürk wanted to create a true national bank to finance various domestic infrastructure projects; İş Bank, founded in August 1924, assumed this enormous task. Ziraat Bank ${ }^{17}$ (Agricultural Bank) primarily focused on serving the financial needs of farmers who are still a significant part of the Turkish economy (e.g. Marois \& Güngen, 2016).18 Atatürk also ordered the name of the Imperial Ottoman Bank to be changed back to the Ottoman Bank and allowed it to remain as a state-owned bank with limited central bank functions until 1931 (Turkey's central bank was finally created in June 1930 but began its operation on October 3, 1931).19

Almost a century after its creation, still whether Turkey's central bank (TCMB) is independent or it is acting under pressure is a hotly debated topic. The truth is, TCBM has never been independent (i.e. maybe briefly after 2001); President Erdogan's sacking of central bank governor Murat Cetinkaya on 6 July 2019 sent a strong signal, removing all doubts that TCMB was independent as long as the signals given by the executive presidency were included in monetary policy decisions. With Turkish economy bent to the president's will, and with TCMB's increasingly shaky monetary policy credibility, all risks (endogenous, exogenous, geopolitical and COVID-19 related) are tilted downside.

\footnotetext{
15 Monetarists like the influential British economist John Maynard Keynes argues in favor of government intervention during challenging economic times because sovereign states have resources large enough to create economic activity.

16 The Ottoman Empire never borrowed money from other nations until the Crimean War (1853-56); paper banknotes (Kaime) were printed in 1840, which later became worthless due to hyperinflation. For the repayment of war reparations and the Empire's outstanding external debts, Ottoman Bank (Ottoman Turkish: Bank-ı Osmanî) was established in 1856 with British capital and was headquartered in London. In 1863, the Ottoman Bank was restructured under the name of Imperial Ottoman Bank which was established by the Ottoman Empire in partnership with English-French financiers; the bank served as the Empire's Treasury with central bank functions.

17 The Homeland Funds was established in 1863, the name of which was changed to Ziraat Bank in 1888

18 Establishment of other important state-owned banks; Halkbank (May 23, 1938), Vakif Bank (January 11, 1954).

${ }^{19}$ Atatürk initiated the establishment of a couple more new banks into the country's growing financial system; Sümerbank in 1932 and Etibank in 1935. Before the start of World War II, Atatürk's reforms helped Turkey create a financial sector of its own that provided necessary financial means to develop other vital industries.
} 


\subsection{Backsliding on Competitiveness}

Since Mustafa Kemal Atatürk created the Republic of Turkey ${ }^{20}$ from the ashes of an ill-Ottoman Empire, Turkey's economic progress has been robust (GDP 6\% or more); however, its impressive performance has been disrupted by repeated military coups, chronic deficits, economic/financial crises, political turmoil arising from a confluence of domestic and external developments, and now the extraordinary cost impact of the Great Lockdown due to the devastating COVID-19 pandemic, which could potentially toss Turkey out of the G20 group as Turkey's GDP is forecast to contract at least 3\% in 2020 (i.e. $\$ 650$ billion) - currently 20th (dropped 3 positions since 2016, see Table 3).

Table 3: G20 countries

\begin{tabular}{|c|c|c|c|c|c|}
\hline Rank & Country & Last & Previous & Date & Unit \\
\hline 1 & United States & 21200 & 20544 & Dec/19 & USD Billion \\
\hline 2 & China & 14200 & 13608 & Dec/19 & USD Billion \\
\hline 3 & Euro Area & 14000 & 13670 & Dec/19 & USD Billion \\
\hline 4 & Japan & 5110 & 4971 & Dec/19 & USD Billion \\
\hline 5 & Germany & 4040 & 3997 & Dec/19 & USD Billion \\
\hline 6 & United Kingdom & 2910 & 2855 & Dec/19 & USD Billion \\
\hline 7 & France & 2890 & 2778 & Dec/19 & USD Billion \\
\hline 8 & India & 2800 & 2719 & Dec/19 & USD Billion \\
\hline 9 & Italy & 2030 & 2074 & Dec/19 & USD Billion \\
\hline 10 & Brazil & 2020 & 1869 & Dec/19 & USD Billion \\
\hline 11 & Russia & 1750 & 1658 & Dec/19 & USD Billion \\
\hline 12 & Canada & 1740 & 1709 & Dec/19 & USD Billion \\
\hline 13 & South Korea & 1690 & 1619 & Dec/19 & USD Billion \\
\hline 14 & Spain & 1460 & 1426 & Dec/19 & USD Billion \\
\hline 15 & Australia & 1450 & 1432 & Dec/19 & USD Billion \\
\hline 16 & Mexico & 1200 & 1221 & Dec/19 & USD Billion \\
\hline 17 & Indonesia & 1126 & 1042 & Dec/19 & USD Billion \\
\hline 18 & Netherlands & 951 & 913 & Dec/19 & USD Billion \\
\hline 19 & Saudi Arabia & 785 & 782 & Dec/19 & USD Billion \\
\hline 20 & Turkey & 740 & 767 & Dec/19 & USD Billion \\
\hline 21 & Switzerland & 715 & 706 & Dec/19 & USD Billion \\
\hline
\end{tabular}

Source: Trading Economics; https://tradingeconomics.com/country-list/gdp?continent=g20

Like President Erdoğan, Prime Minister Adnan Menderes in the 1960s argued that the IMF wanted to put a rein (a leash) on Turkish government by making international borrowing scarce and costly. The IMF opposition gained popularity with Turkish voters who helped Menderes' party win the elections in 1954 and 1958; paradoxically, the partially accepted IMF program in 1958 also brought the DP's

\footnotetext{
20 Mustafa Kemal's well-organized resistance army was victorious in the War of Independence (1919-1923). Subsequently, armies of Allied forces were expelled from the occupied Turkish land; Mustafa Kemal famously said "they will go as they came"; he abolished the Ottoman Empire in 1922 by overthrowing Sultan Mehmet VI Vahdettin and established Turkish Republic on October 29, 1923. Mustafa Kemal was elected as the first President in 1923 and the Grand National Assembly of Turkey (TBMM) honored him with the title (last name) Atatürk in 1934 which means the "Father of the Turks".
} 
demise $^{21}$ and the subsequent military coup on May 27, 1960 (see Conway, 2007; Joyce, 2006; Singer, 1977). There were four more military interventions, in 1971, 1980, 1997, and 2016 but the latter two were different from the former three. The coup of 1997 was called a "soft coup" because the Turkish military did not take full control of the government, instead put immense pressure on Prime Minister Necmettin Erbakan and his party to resign, the closure of which paved the road for the establishment of the current ruling Justice and Development Party (AKP) in 2001. The failed coup in 2016 was called "an attempt" because it was not a full-fledged military takeover, mainly an uncoordinated (sloppy) act by a fraction of military forces that did not follow a complete (top-to-bottom) chain of command. Every decade starting with the 1960s had extraordinary events that forced Turkey to go backward for a decade or two in terms of economic and social development performance (Table 4).

Table 4: GDP and GDP per capita annual growth

\begin{tabular}{|c|c|c|c|c|c|}
\hline Date & $\begin{array}{c}\text { Annual GDP } \\
\$ \text { million }\end{array}$ & $\begin{array}{c}\text { GDP Growth } \\
\% \\
\end{array}$ & Date & $\begin{array}{c}\text { GDP Per Capita } \\
\$\end{array}$ & $\begin{array}{l}\text { GDP P.C. Annual } \\
\text { Growth \% }\end{array}$ \\
\hline 2019 & 771,274 & 0.9 & 2019 & 8,958 & -4.75 \\
\hline 2018 & 771,400 & 2.8 & 2018 & 9,405 & -10.9 \\
\hline 2017 & 852,648 & 7.5 & 2017 & 10,551 & -2.5 \\
\hline 2016 & 863,390 & 3.2 & 2016 & 10,817 & -0.9 \\
\hline 2015 & 859,449 & 6.1 & 2015 & 10,915 & -9.2 \\
\hline 2014 & 934,075 & 5.2 & 2014 & 12,022 & -3.0 \\
\hline 2013 & 950,328 & 8.5 & 2013 & 12,395 & 7.3 \\
\hline 2012 & 873,696 & 4.8 & 2012 & 11,553 & 3.7 \\
\hline 2011 & 832,497 & 11.1 & 2011 & 11,141 & 6.4 \\
\hline 2010 & 772,290 & 8.5 & 2010 & 10,476 & 17.9 \\
\hline 2009 & 644,470 & -4.7 & 2009 & 8,882 & -16.9 \\
\hline 2008 & 764,643 & 0.8 & 2008 & 10,692 & 11.8 \\
\hline 2007 & 675,010 & 5.0 & 2007 & 9,563 & 21.1 \\
\hline 2006 & 550,796 & 7.1 & 2006 & 7,899 & 8.5 \\
\hline 2005 & 501,163 & 9.0 & 2005 & 7,278 & 22.3 \\
\hline 2004 & 404,853 & 9.6 & 2004 & 5,953 & 28.2 \\
\hline 2003 & 311,944 & 5.6 & 2003 & 4,643 & 29.4 \\
\hline 2002 & 238,342 & 6.4 & 2002 & 3,589 & 17.6 \\
\hline 2001 & 200,305 & -6.0 & 2001 & 3,053 & -27.6 \\
\hline 2000 & 273,085 & 6.6 & 2000 & 4,219 & 5.0 \\
\hline 1999 & 256,485 & -3.4 & 1999 & 4,019 & -8.4 \\
\hline 1998 & 276,012 & 4.6 & 1998 & 4,387 & 4.0 \\
\hline 1997 & 261,775 & 7.5 & 1997 & 4,221 & 3.1 \\
\hline 1996 & 250,263 & 7.0 & 1996 & 4,096 & 5.6 \\
\hline 1995 & 233,340 & 7.2 & 1995 & 3,877 & 28.2 \\
\hline 1994 & 179,208 & -5.5 & 1994 & 3,024 & -29.0 \\
\hline
\end{tabular}

Source: Countryeconomy.com; https://countryeconomy.com/gdp/turkey

\footnotetext{
21 Following the May 27, 1960 military coup, both President Celal Bayar and Prime Minister Adnan Menderes were arrested and found guilty by the military court. Celal Bayar, longest lived state leader (1883-1986), was Prime Minister (1937-39) and President (1950-60) was sentenced to life imprisonment, but he was released in 1964 due to poor health and pardoned in 1966. Unfortunately, Prime Minister Menderes was not as lucky, who was sentenced to death by hanging. Menderes did not do anything wrong or unlawful to deserve the death penalty. Many years later, the Turkish government apologized for its shameful decision, regardless murdering its prime minister by hanging remains as one of the darkest days in history.
} 
Turkey's economic performance since its most severe economic crisis of 2001 has been remarkable; this impressive record in part was attributable to the non-coalition government under the Justice and Development Party that has won 16 elections since 2002 (President Erdoğan is a founding member), ambitious structural and fiscal reforms, accommodative external environment (i.e. dollar glut due to the Fed's expansive monetary policy along with the historically low interest rates in the U.S.), EUaccession negotiations, and the AKP's fruitful economic stimulus programs (see Önis, 2009; Raina \& Bakker, 2003). However, adverse effects of the influx of about 4.5 million refugees (i.e. 3.6 million from Syria), growing economic vulnerabilities arose from increased tensions between the U.S. and Turkey, and the currency crisis in August 2018 contributed to the AKP's stinging defeats in the 2019 mayoral elections; consequently, for first time since the local elections of 27 March 1994 (Erdoğan was elected Mayor of Istanbul), the opposition party (Cumhuriyet Halk Partisi - CHP) won Istanbul.

A deluge of monetary and fiscal reforms between 2002 and 2009 have fueled a broad rally in Turkish economy; however, in the past few years (since 2013), exogenous (hostile external environment) and endogenous (deficits and political turmoil) risks reversed two decades of progress made to date. ${ }^{22}$ For example, the GDP per capita in Turkey has dropped for six consecutive years, from \$12,395 (peak) in 2013 to \$8,958 in 2019 (i.e. 2006 level); furthermore, the impact of the coronavirus crisis (i.e. Great Lockdown beginning in mid-March, i.e. 9 weeks of partial lockdowns enforced on the weekends and national holidays) will cause the Turkish economy to contract 3\% or more in 2020 (downgraded from $+3.9 \%$ growth); as a direct consequence of the AKP's poor performance in GDP growth (Figure 3) and job creation (Figure 2), Turkish people are a lot poorer now than they were in 2013.

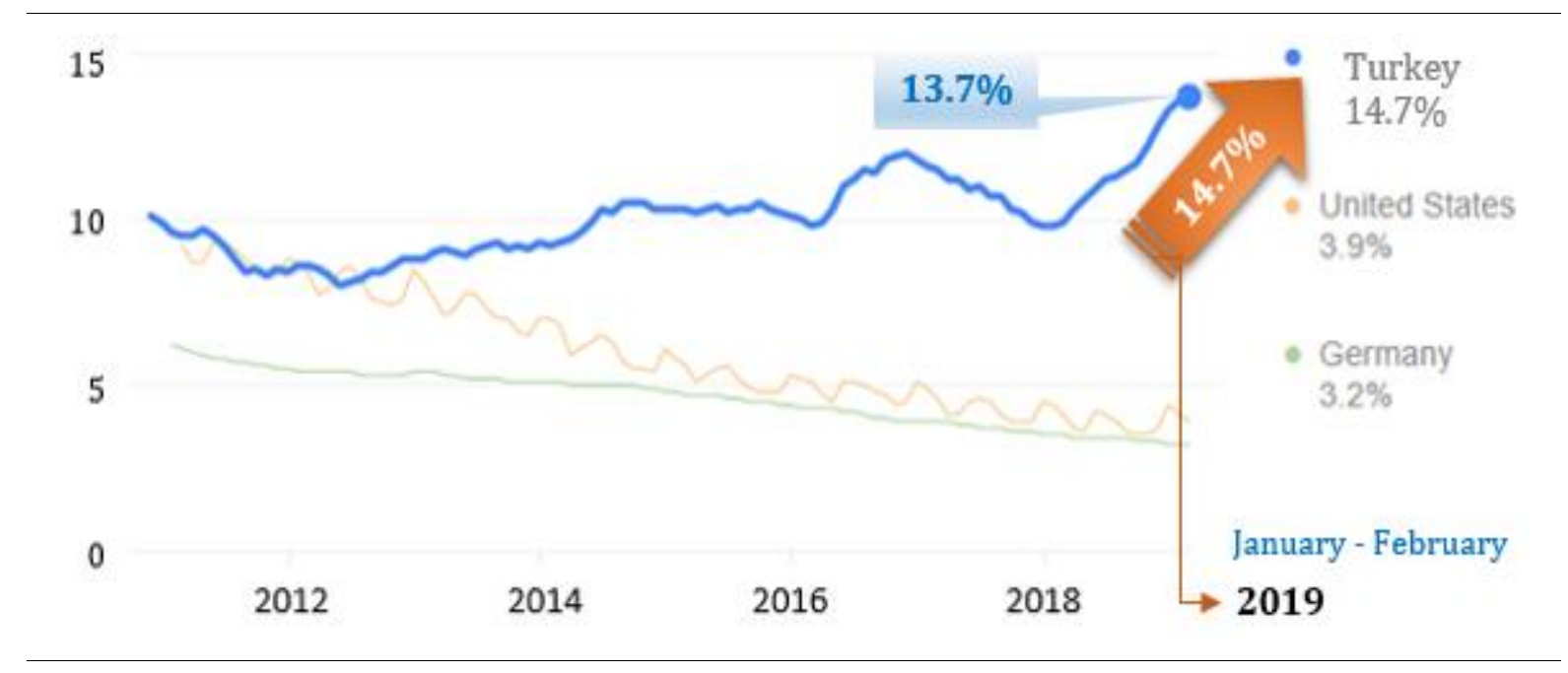

Source: World Bank; http://datatopics.worldbank.org/world-development-indicators/

Figure 2: Turkey unemployment rates (2012-2018)

22 https://www.worldbank.org/en/country/turkey/overview 
Turkey's risk premia has risen rapidly following the 2016 failed military coup attempt and climaxed in the aftermath of the currency shock in August 2018, the amplified risk premia severely impacted every area in Turkish economy which has been on a roller-coaster ride in terms of interest rates and inflation. In October 2018 (Figure 4), core inflation (CPI) hit 25\% while producer price index reached $50 \%$; similarly, interest rates hit the roof; $36 \%$ for commercial loans, $28 \%$ for housing loans, and as high as $24 \%$ for bank deposits in lira. After several rigorous monetary easing actions by the Turkish central bank (TCMB), the policy rate was cut from 24\% in June 2019 to 8.75\% in April 2020; same way, the core inflation declined to $8.6 \%$ in October 2019 after peaking at $25 \%$ a year ago, however severe impact of COVID-19 pandemic has triggered a spike in inflation (over 12\% in February 2020).

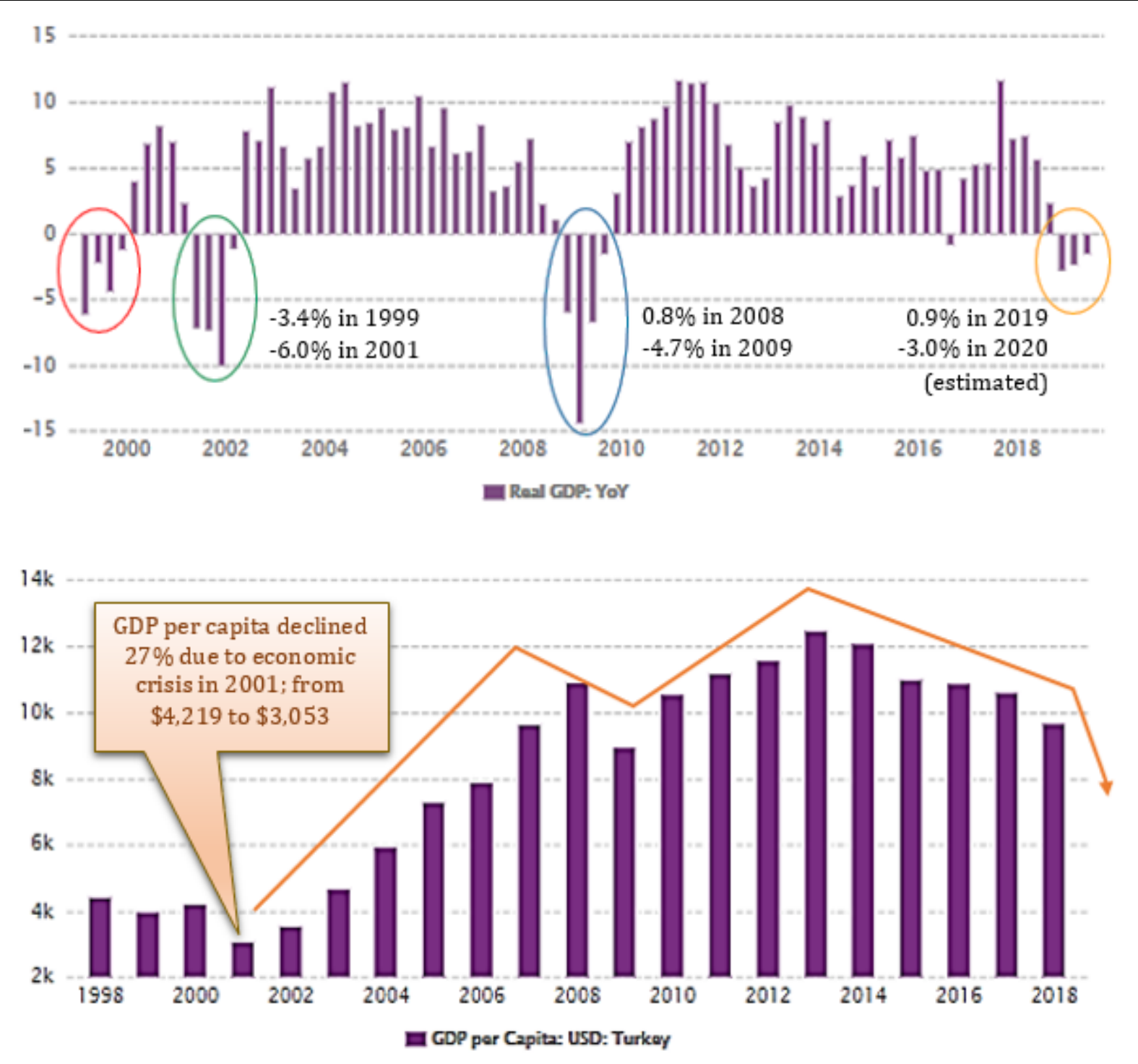

Source: World Bank; https://www.ceicdata.com/en/indicator/turkey/gdp-per-capita

Figure 3: Turkey real GDP (\%) and GDP per capita (\$) 


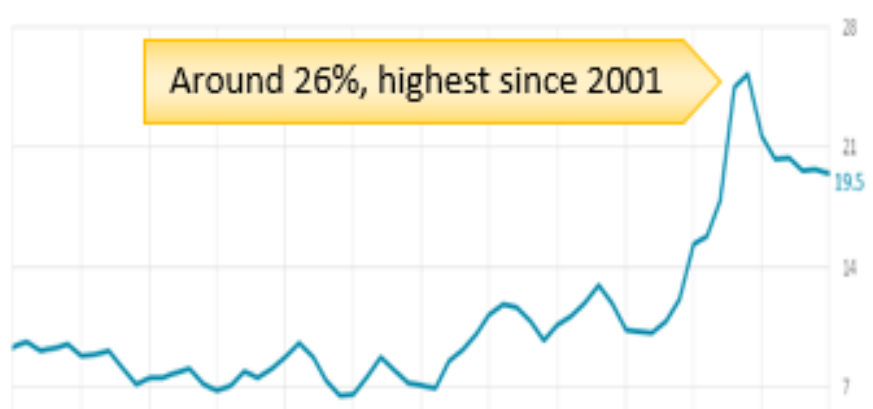

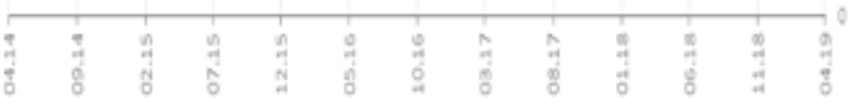

A. Consumer Price Index (CPI) - Annual Change (\%)

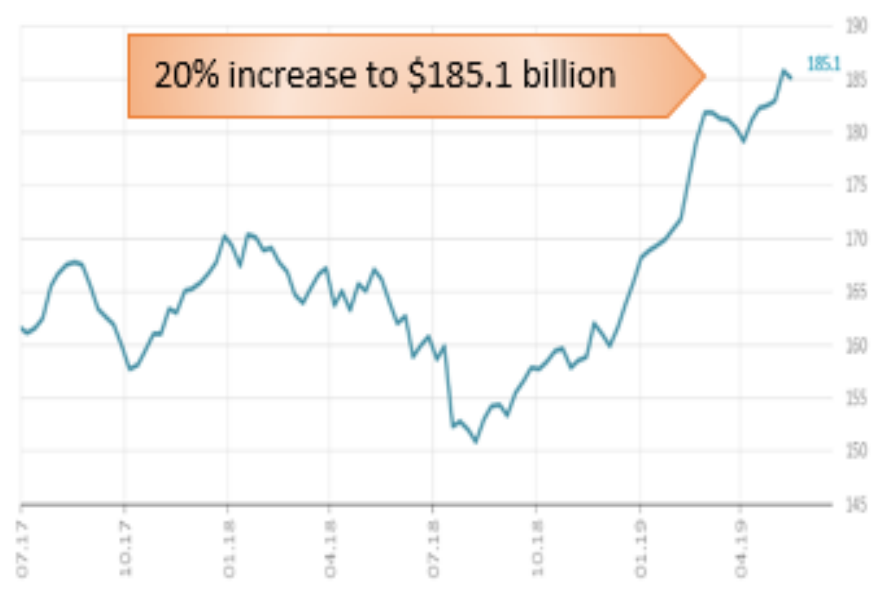

C. Resident's FX Deposits with Banks (Billion \$)

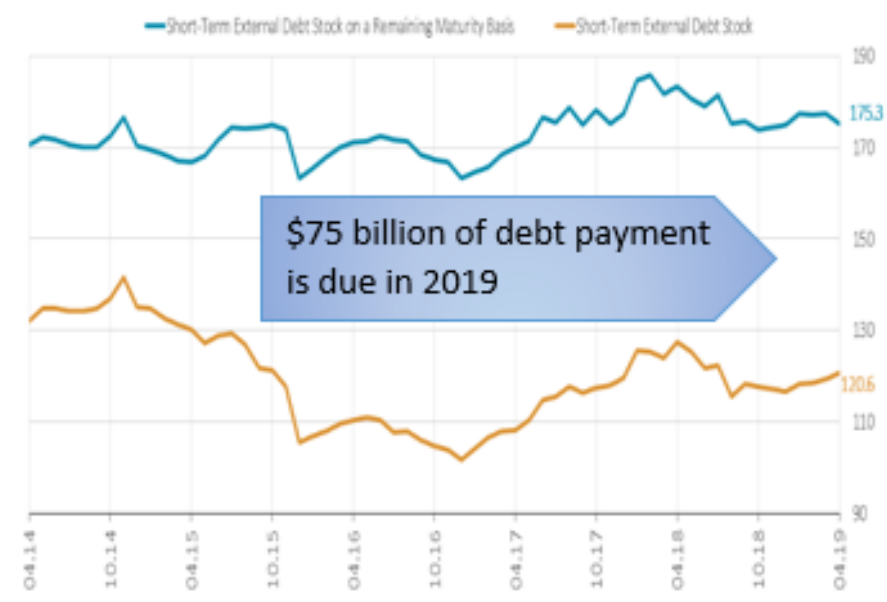

E. Short-Term External Debt Statistics (Billion \$)

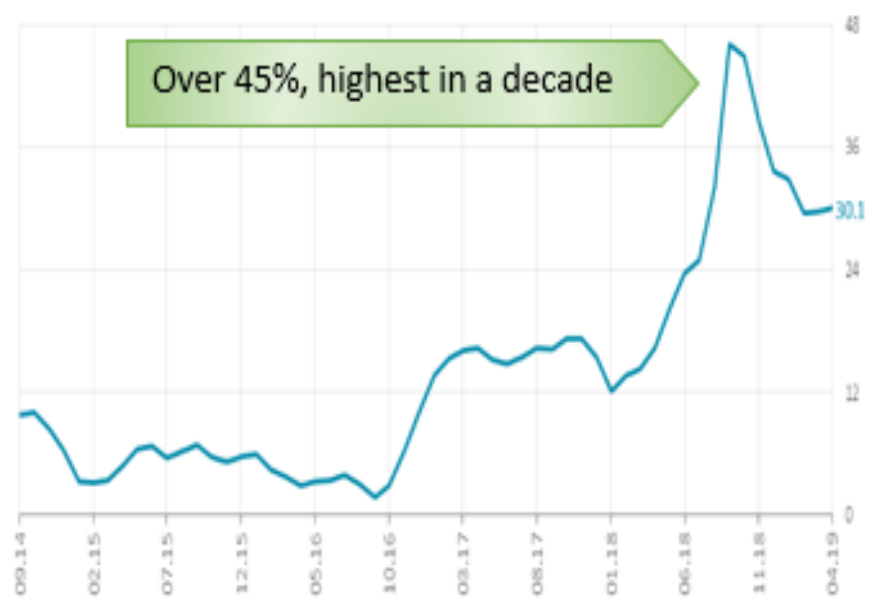

B. Producer Price Index (PPI) - Annual Change (\%)

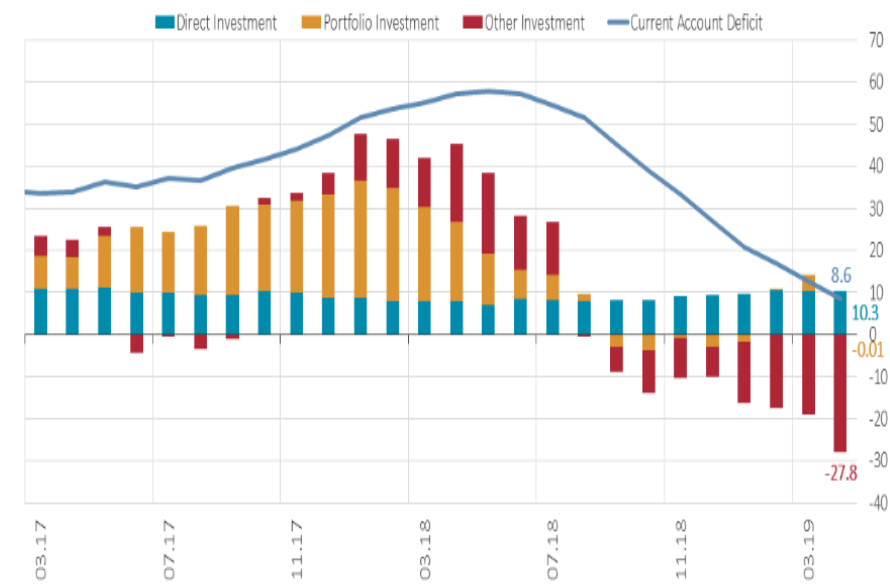

D. International Investment Position (Billion \$)

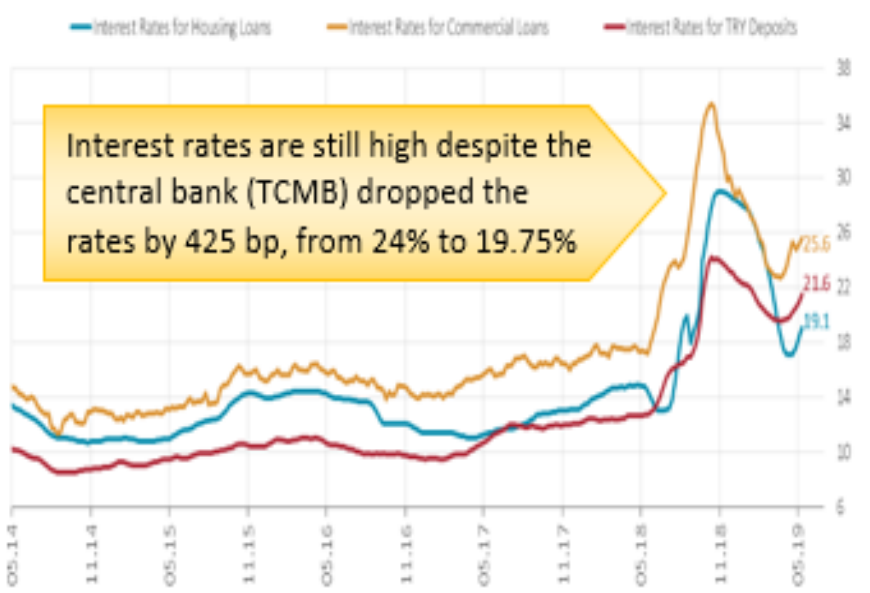

F. Interest Rates for Banks' Loans and Deposits (\%)

Source: TCMB - Turkish Republic Central Bank

https://www.tcmb.gov.tr/wps/wcm/connect/EN/TCMB+EN/Main+Menu/Statistics/Chart+Gallery

Figure 4: Various economic indicators of Turkish economy 
During a century of history as an independent state following Ottoman Empire's dissolution (12991922), the Republic of Turkey (since 1923) has endured many obstacles, challenges, and paradigmshifting crises that often led to a military coup or vice versa (Table 5, also see Figure 3and 4).

Table 5: Turkish history of unprecedented events

\begin{tabular}{c|l}
\hline Event & \multicolumn{1}{|c}{ Economic/Social Developments } \\
\hline \multirow{2}{*}{1} & $\begin{array}{l}\text { Severe economic recession; socio-political turmoil; American } \\
\text { aid ran out, Marshall Plan ended and Prime Minister Adnan } \\
\text { Menderes approached Moscow for lines of credit; May 27, } \\
\text { 1960 the Turkish armed forces took control (coup); president } \\
\text { (Celal Bayar) and prime minister Adnan Menderes among } \\
\text { others were arrested and prosecuted for charges of high } \\
\text { treason; Celal Bayar was sentenced to life imprisonment and }\end{array}$ \\
& $\begin{array}{l}\text { Adnan Menderes was sentenced to death by hanging. } \\
\text { The extreme Islamist movement turned into a state of chaos In } \\
\text { the early 1970s; public disorder and political terrorism grew } \\
\text { substantially; the Chief of Turkish Armed Forces handed prime } \\
\text { minister Süleyman Demirel a memorandum (March 12, 1971) } \\
\text { known as 'coup by memorandum'; ongoing and severe clashes } \\
\text { between left-wing and right-wing groups who often carried } \\
\text { out bombing attacks and violent acts; the extreme Islamist } \\
\text { movement rejected Atatürk and his principles. }\end{array}$ \\
\hline \multirow{2}{*}{2} &
\end{tabular}

Süleyman Demirel succeeded Bülent Ecevit as prime minister in 1975 formed a coalition government (4 different parties); amplified economic/social problems and the ensuing extreme violence in the late 1970s; The 1980 coup d'état was welcome to restore order and stop the ongoing socio-political violence since the 1960s; National Security Council was in charge of the government from 1980 to the 183 general election;

Negative impacts of the 1991 Persian Gulf War and embargos placed by the UN cost the Turkish economy between $\$ 3$ and $\$ 5$ billion; favorable ratings by the US credit rating agencies in

$4 \quad 1992$ and 1993; short-term debt increased significantly which caused a huge rise in dollarization; the government requested about $\$ 1$ billion from the IMF; unresolved economic problems resulted in a currency crisis.

Political instability increased immensely after the 1997 postmodern coup; the massive Marmara earthquake in 1999 only made the matter worse (over 18,000 people died); Prime Minister Ecevit, after meeting with President Nejdet Sezer, characterized the meeting as "a serious crisis" this prompted a panic-induced heavy sell-off in stock market.

Turkey's remarkable economic performance since 2002 (6\% YoY GDP growth) was halted by the 2008 global financial crisis

6 originated in the U.S.; President Erdogan's remarks at the 2009 Davos and his repeated criticism of the IMF had a straining effect on Turkey's relations with its neighboring countries.

Strained Turkey-Cyprus relations as Cyprus vetoed chapter 15 of Turkey's EU accession negotiations; conviction of the U.S. pastor Andrew Brunson of terrorism charges and taking part in the 2016 failed coup attempt; Turkey's purchase of Russian S-400 defense system; removal of Turkey from F-35 program.
Outcomes

Economic recession, violence, instability; military coup on May 27, 1960; prime minister Adnan Menderes was executed by hanging (Sept. 16, 1961); IMF stand-by program was signed in 1961; on July, 1961 constitutional referendum was held which replaced one from 1924; two failed coup attempts in 1962 and 1963.

Socio-political turmoil grew in the 1970s; Prime Minister Süleyman Demirel's Justice Party lost parliamentary majority as some members defected to form own groups; a new wave of terror led to martial law and repression; the military memorandum of 1971 ousted prime minister Demirel and set the stage for another coup in 1980.

The 1980 coup (September 12) overthrew the government and issued a martial law; all political parties and trade unions were banned; the constitution was suspended; the economy was on the verge of collapse, high unemployment, deficits, and inflation, but improved in second half of the 1980s.

Unresolved economic problems, political turmoil, social unrest, and ineffectiveness of the coalition government, (Tansu Çiller was Prime Minister, 1993-1996) led to the 1997 military memorandum (28 February also called 'Post-modern coup'). Erbakan's Welfare Party was closed.

The economic crisis of 2001 was the worst in Turkish history (GDP contracted 6\%); central bank's foreign reserves declined by $\$ 5$ billion; several banks became insolvent or bailed out; Turkish lira depreciated at least 50\%; 15,000-20,000 jobs were lost.

Severe recession; augmented geopolitical risks caused a huge fall in foreign demand; unemployment rate rose by $5 \%$; industrial production fell about 50\% and the GDP contracted by $-4.7 \%$ (worst since 2001 ).

The U.S. imposed sanctions/tariffs on steel imports from Turkey; repeated attacks on Turkish lira resulted in a severe currency crisis; the value of lira plummeted against the dollar (see Figure 4 on next page).

Source: Author 


\subsection{Backsliding on Democracy}

Turks $^{23}$ have been around for 4000 years, who established many states and empires ${ }^{24}$ in the "land of Turks" referring to Anatolia (Asia Minor) and Eastern Thrace (European part of Turkey) ${ }^{25}$. However, the key elements of democracy has been arcane to Turks until Mustafa Kemal (a brilliant man, superb military commander, genius, and envied politician/president) ended over six centuries-long Ottoman rule. His well-organized resistance army was victorious in the War of Independence (1919-1923), the armies of Allied forces were expelled; subsequently, Mustafa Kemal abolished the Ottoman Empire in November $1922^{26}$ by overthrowing Sultan Mehmet VI Vahdettin and established Turkish Republic on October 29, 1923 (The Grand National Assembly elected Mustafa Kemal as President in 1923).27

The life of Turks, previously in the Altai Mountains of western Mongolia, commenced in the interior of Asia Minor (modern Turkey) when Seljuqs defeated the Byzantines at Manzikert in 1071 (Malazgirt in Turkish), which also meant the start of Turkification of Asia Minor. The successor Ottomans (tribal leader and founder Osman I) established the Ottoman Empire (1299-1922) that conquered lands in Southeastern Europe, Central Europe, Western Asia, and Northern Africa. ${ }^{28}$ However, after 623 years of strict Ottoman rule, Turkey's transition from sultanate to democracy in the 20th century was rather painful, underpinned by developments in the aftermath of Atatürk's death (November 10, 1938); as such, chronic socio-political turmoil, repeated military interventions (coup d'état), and the spin-off crises (financial, economic, currency, and societal). Although not a full-fledged democracy, to start the process, Atatürk formed the Republican People's Party (Cumhuriyet Halk Partisi - CHP in Turkish) in 1923 which inaugurated the single-party era (e.g. Rustow, 1957; Harris, 1965).

Mustafa Kemal Atatürk's closest associate Ismet Inönü became president after his death in 1938, but the timing could not have been any worse. Although Turkey stayed neutral, the outbreak of World War II (1939-45) triggered a surge in Turkey's military spending which rose from $25 \%$ to $60 \%$ of the government budget. By the conclusion of WWII, Turkish economy was in severe recession; per capita income and agricultural output fell circa 30\%, inflation skyrocketed (as high as 300\%), and 80\% of the Turkish lira's value depreciated against major currencies during 1938-45 (see Altug et al., 2008;

23 Turkic refers to Turkish people, Azerbaijanis, Uzbeks, Kazakhs, Turkmens, Kyrgyz and Uyghur people.

24 The Great Hun Empire (370s-469), the Göktürk Empire (552- 740), the Uygur Empire (741- 840), the Avar Empire (600900), the Hazar Empire (500-1000), the Great Seljuk Empire (1040-1157), and the Ottoman Empire (1299-1922).

25 Wikipedia, https://en.wikipedia.org/wiki/History_of_Turkey

26 The Grand National Assembly of Turkey on 1 November 1922 ended the Ottoman Empire, which was recognized on 11 November 1922 at the Conference of Lausanne.

27 The last sultan, Mehmed VI Vahdettin (reigned 1918-22), was forced to leave the country on 17 November 1922.

28 Countries that were once under the Ottoman rule. Bulgaria, Egypt, Greece, Hungary, Jordan, Lebanon, Israel and the Palestinian territories, Macedonia, Romania, Syria, parts of Arabia, the north coast and the horn of Africa. 
Boratav, 2009). Economic problems of the war years and the capital levy29 introduced by the Inönü administration to raise money to meet the country's debt obligations took a heavy toll on his political career prospects (Akın, 2002; Albayrak, 2004; Kibritçioğlu, 2001; Nas, 2008). Consequently, the CHP’s single-party dominance 30 took a major blow in the 1946 general election; Democrat Party (DP) also founded in 1945 won 61 seats (e.g. Karpat, 1959; Weiker, 1975), but the transition into a multi-party political system commenced strongly when the DP won 396 out of 487 seats (i.e. claimed $54 \%$ of the votes) in the $1950^{31}$ general election; Celal Bayar ${ }^{32}$ became President and Adnan Menderes became Prime Minister (Lipovsky, 1991; Szyliowicz, 1966; Schick \& Tonak, 1987; Özbudun, 1976). ${ }^{33}$ However, Menderes and his party became the target of international aggression campaign as he rejected the IMF's politically motivated policy advice and accused the IMF for its recidivism and contractionary measures (Bas \& Stone, 2010; Bird et al., 2004; Conway, 2007; Joyce, 2006; Singer, 1977). ${ }^{34}$

September 16, 1961 was the darkest and most shameful day in Turkey's young history of transition to democracy; following the 1960 coup d'état (May 27), the Turkish Prime Minister Adnan Menderes along with his two ministers Hasan Polatkan and Fatin Rüştü Zorlu were executed by hanging. ${ }^{35}$ It is true that, since the Justice and Development Party (AKP) won the general elections in 2002 (party's leader Recep Tayyip Erdoğan became prime minister), Turkey has moved away from its tradition of facing one military coup in every decade since the 1960s (excluding the July 2016 failed coup attempt by a fraction of the arm forces); but given Turkey's current government's ever more authoritarian rule, it is hotly debated whether the past two decades of democratic and economic developments have been more damaging or beneficial. ${ }^{36}$ The ruling AKP's promise of making solid reforms left its place to more dictatorial/dysfunctional politics and laws that have been purposely designed to suppress the citizens of Turkey; consequently, once highly praised AKP (i.e. democratic progress, EU accession negotiations, growth in GDP and GDP per capita) is now immensely criticized.

\footnotetext{
${ }^{29}$ At the time of capital levy (1942), mostly non-Muslim people (Greeks and Armenians) and Jews who converted to Islam had taxable wealth, but this was seen as a punitive punishment and angered these communities. Turkey was not alone, many European countries introduced capital levies during or after both WWI and WWII.

30 CHP's policies were based on Mustafa Kemal's six principles which were also basis of Turkey's first constitution written in 1937; republicanism, nationalism, populism, statism, secularism, and revolution.

31 In the 1950 elections, Democrat Party (DP) won 396 of 487 seats compared with only 68 seats won by CHP.

32 Celal Bayar, longest lived state leader (1883-1986), was Prime Minister (1937-39) and President (1950-60). On 27 May 1960 coup, along with Prime Minister Adnan Menderes, President Celal Bayar was sent to military court which convicted him to life imprisonment. He was released in 1964 due to poor health and pardoned in 1966.

33 Prime Minister Adnan Menderes was arrested, prosecuted and sentenced to death. Menderes did not do anything unlawful to deserve the death penalty. Many years later, the Turkish government apologized for its decision.

34 The military coup of 1960 marked the IMF rein on Turkey's economy. There were two more coups in 1971 and 1980 , and the most recent coup attempt on July 15, 2016 by a fraction of the Turkish Armed Forces.

35 At the time of writing this article, the Turkish Parliament on 23 June 2020 unanimously passed a bill to make the Yassiada trials and the related decisions void; however, declaring the event and the decisions taken in 1960 invalid will neither undo the history nor will it remove the shameful stain deeply engraved in Turkey's premature democracy.

36 https://www.brookings.edu/research/the-rise-and-fall-of-liberal-democracy-in-turkey-implications-for-the-west/
} 
There have been numerous endogenous (internal) and exogenous (external) factors that contributed to Turkey's backslide on democracy, i.e. due to acrimonious relations with European and the Middle Eastern neighbors (especially since Prime Minister Erdoğan walked off the stage at the 2009 Davos summit over clash in Gaza and accused Israeli President Shimon Peres and his country for engaging in inhumane treatment of Palestinians), all of the democratic gains achieved early on have vanished completely (see Table 3 for a brief history of unprecedented events in Turkey). Table 6 illustrates a list of internal and external factors that have contributed to Turkey's democratic regression.

Table 6: Internal and external factors for Turkey's backsliding on democracy

\begin{tabular}{|c|c|}
\hline Endogenous - internal factors 37 & Exogenous - external factors \\
\hline $\begin{array}{l}\text { - Chronic deficits; budget, current account, trade. } \\
\text { - High inflation, interest rates, and weak currency. } \\
\text { - Political turmoil due to many coalition governments; } \\
\text { four between } 1973 \text { and } 1980 \text { and seven } 1991 \text { and } 2002 . \\
\text { Only four single-party governments; Democratic Party } \\
\text { (1950-1960), Justice Party (1965-1971), Motherland } \\
\text { Party (1983-1991), and Justice and Development Party } \\
\text { (2002-present); most dictatorial/authoritarian so far. } \\
\text { - Repeated military coup d'état and memorandum; 1960, } \\
\text { 1971, 1980, 1997, and 2016. } \\
\text { - Negative developments; rule of law, human rights, basic } \\
\text { fundamentals, and the Judiciary/legal system. } \\
\text { - Turkey's cross-border military operations in Syria, Iraq, } \\
\text { - Libya, and counter-terrorism against PKK. } \\
\text { Fast deterioration in fundamental freedoms since the } \\
\text { July } 15,2016 \text { failed coup attempt by a fraction of the arm } \\
\text { forces, and an increase in detentions, dismissals, powers } \\
\text { of the government through authoritarian rule. } \\
\text { - Constrained civil, political, and defense rights; expanded } \\
\text { powers for the police and state prosecutors. } \\
\text { - Decrees issued during the state of emergency are not } \\
\text { open to review; ineffective domestic legal remedy led to } \\
\text { the rejection of thousands of complaints. } \\
\text { - Due to administrative obstacles, still a great number of } \\
\text { people are detained without indictment. } \\
\text { - Countless civil society and rights-based organizations } \\
\text { have been closed without any legal remedy. } \\
\text { - The new presidential system centralized power in the } \\
\text { hands of one man (i.e. President Erdogan). } \\
\text { - The Parliament's legislative and oversight functions } \\
\text { have been severely curtailed (almost symbolic now). } \\
\text { - Political polarization and marginalization of opposition } \\
\text { - The (i.e. HDP) have increased significantly. } \\
\text { the elected mayors were declared ineligible to run office. } \\
\text { - Politicization of the public administration. }\end{array}$ & $\begin{array}{l}\text { - Geopolitical risks due to growing diplomatic tensions } \\
\text { are on the rise and their negative impact on Turkish } \\
\text { economy has been more significant than ever before. } \\
\text { - Geopolitical conflicts Turkey has engaged in have set a } \\
\text { climate of uncertainty, this has caused international } \\
\text { investors to hold back investments, which are crucial } \\
\text { for Turkey's development programs. } \\
\text { - Due to acrimonious relations with most neighbors } \\
\text { (especially with the U.S.), democratic gains achieved } \\
\text { for the past two decades (since } 2002 \text { ) have eroded, the } \\
\text { hindered economic growth left its place to contraction, } \\
\text { and EU accession negotiations are ground to a halt. } \\
\text { - Unstable geopolitical situation in Syria, Iraq, and Iran } \\
\text { forced nearly } 4 \text { million refugees to migrate to Turkey, } \\
\text { which put immense pressures on its already fragile } \\
\text { economy; the government claims thatithas spent over } \\
\text { \$40 billion on refugees. } \\
\text { - The EU suspended the opening of eight chapters on } \\
\text { Customs Union (Dec. } 2006 \text { ); the negotiations will not } \\
\text { resume until Turkey opens its ports (sea and air) to } \\
\text { Greek-Cypriot traffic. } \\
\text { - Turkey-Cyprus relations were severely strained when } \\
\text { France and Cyprus unilaterally blocked chapters, and } \\
\text { in December } 2009, \text { Cyprus vetoed the opening of the } \\
\text { chapter } 15 \text { related to energy. } \\
\text { - Massive costs of the coronavirus crisis will surge with } \\
\text { the potential second or third wave of the CovID-19 } \\
\text { insurgence (i.e. the cost could be } \$ 50 \text { billion). } \\
\text { - Arrest, prosecution and conviction of the U.S. pastor } \\
\text { Andrew Brunson of terrorism related charges and } \\
\text { taking part in the } 2016 \text { failed coup attempt } \\
\text { - Turkish economy (Aug. } 2018 \text { ), lira depreciated more } \\
\text { than } 50 \% \text { against major currencies. } \\
\text { - All economic indicators in Turkey have recorded their } \\
\text { worst levels. Turkish economy is forecast to contract - } \\
\text { a severe economic crisis is imminent. }\end{array}$ \\
\hline
\end{tabular}

Source: Author

37 Commission Staff Working Document: Turkey 2019 Report. European Commission, Brussels, 29.5.2019, SWD(2019) 220 final (Communication from the Commission to the European Parliament, the Council, the European Economic and Social Committee and the Committee of the Regions, 2019 Communication on EU Enlargement Policy. COM (2019) 260 final). 


\subsection{Methodology}

The World Economic Forum (WEF) defines global competitiveness as "the set of institutions, policies, and factors that determine the level of productivity of an economy, which in turn sets the level of prosperity that the economy can achieve". A wide spectrum of ways a country's competitiveness is measured, but analyses in this study are based on the Global Competitiveness Index (GCI) published by the WEF annually, which tracks 114 indicators grouped into 12 pillars (see Figure 5) that are then organized into three sub-indexes (see Table 7); (1) basic requirements; (2) efficiency enhancers; (3) innovation/sophistication factors. The GCI includes statistical data from multilateral organizations such as the International Monetary Fund (IMF), World Bank, UNESCO, World Health Organization (WHO), and International Telecommunication Union (ITU). The WEF underlines that each nation provides own data (i) as is, as available; (ii) makes no representation to the accuracy of the data; and (iii) accepts no liability for any use of the data or any decisions or actions based on it.

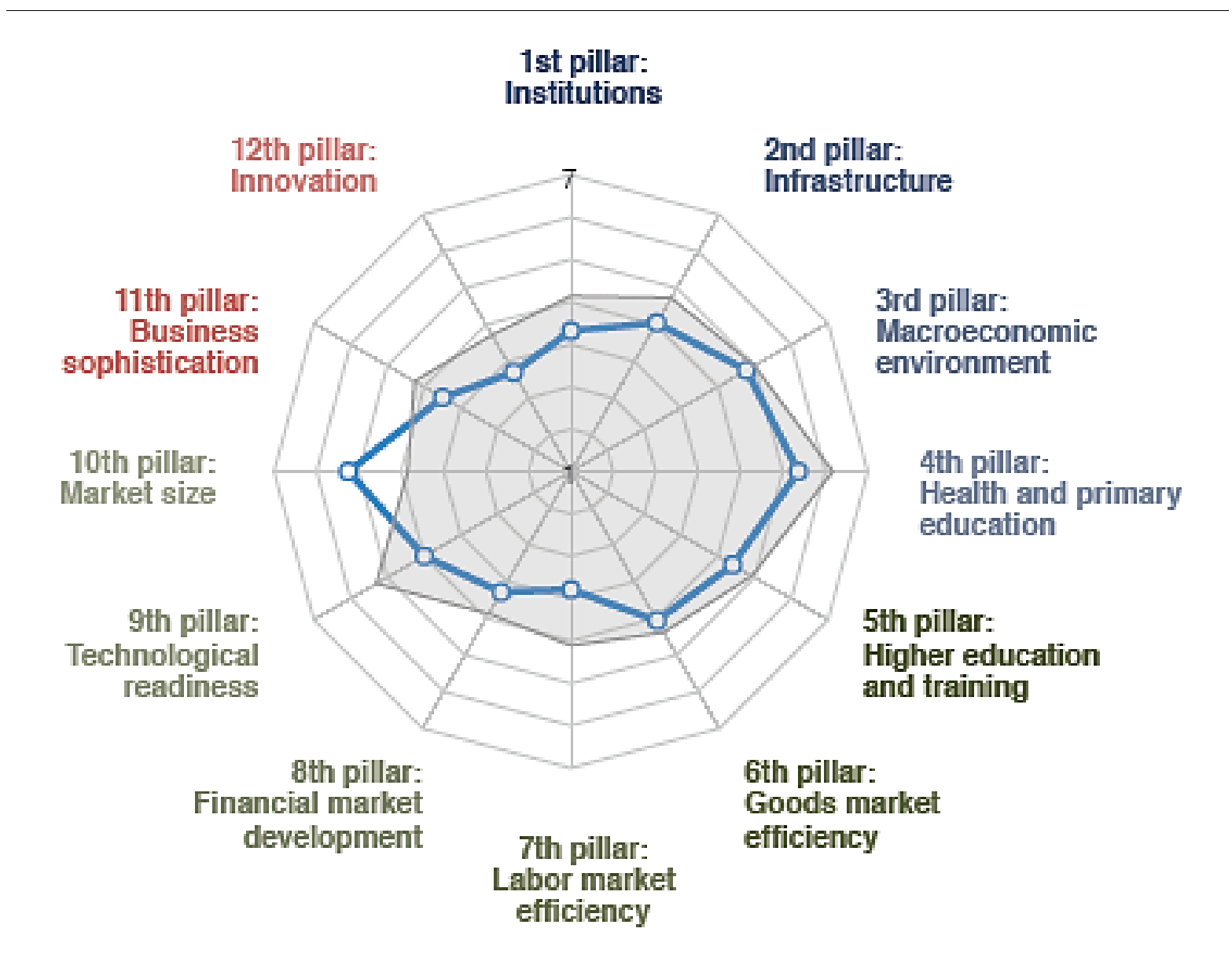

Source: World Economic Forum (WEF); https://www.weforum.org/

Figure 5: Global competitiveness index pillars 
Table 7: List of variables and sample data points

\begin{tabular}{|c|c|c|c|}
\hline \multirow[t]{2}{*}{ Sub-index } & Pillars & Definition & Data Points \\
\hline & GCIOR & Global Competitiveness Index Overall Rank & 114 \\
\hline \multirow[t]{5}{*}{ BR } & & Basic Requirements & 45 \\
\hline & BRINS & Institutions & 21 \\
\hline & BRINF & Infrastructure & 9 \\
\hline & BRMEE & Macroeconomic environment & 5 \\
\hline & BRHPE & Health and primary education & 10 \\
\hline \multirow[t]{7}{*}{$\mathrm{EE}$} & & Efficiency Enhancers & 53 \\
\hline & EEHET & Higher education and training & 8 \\
\hline & EEGME & Goods market efficiency & 16 \\
\hline & EELME & Labor market efficiency & 10 \\
\hline & EEFMD & Financial market development & 8 \\
\hline & EETRD & Technological readiness & 7 \\
\hline & EEMAS & Market size & 4 \\
\hline \multirow[t]{4}{*}{ IS } & & Innovation and Sophistication Factors & 16 \\
\hline & ISBUS & Business sophistication & 9 \\
\hline & ISINN & Innovation & 7 \\
\hline & & Total Data Points & 114 \\
\hline
\end{tabular}

Source: World Economic Forum (WEF); https://www.weforum.org/

\subsection{Research Sample}

The World Economic Forum does not compile the country-specific data employed to calculate country scores for the purpose of its GCI report; various parties within each country compile the data and then provide it to the WEF; however, for some data the WEF may be the source. For our analyses purposes throughout the study, we have extracted GCI data for 32 nations (Turkey, G19 excluding EU as a single economy ${ }^{38}, \mathrm{G8}^{39}$, and ASEAN-540). The sample data for this research comprised 114 rankings per year for ten years from 2009 to 2018 (see Table 7); a total of 1,140 rankings per country were analyzed; since the study compared GCI scores of Turkey with those of G19, G8, and ASEAN-5 countries, thus the final sample size was 36,480 (i.e. 114 x 32) ranking points grouped into 12 pillars.

\subsection{Data Processing}

After the data collection was completed, the data was subject to data screening. There was no missing data, therefore no missing data imputation was necessary. Next, univariate and multivariate outliers were investigated using Z-score and Mahalanobis $\mathrm{D}^{2}$ values. Because there were no extreme outliers

\footnotetext{
38 G19: Argentina, Australia, Brazil, Canada, China, France, Germany, India, Indonesia, Italy, Japan, Korea Republic, Mexico, Russian Federation, Saudi Arabia, South Africa, Turkey, United Kingdom, and United States.

39 G8: Canada, France, Germany, Italy, Japan, Russian Federation, United Kingdom, and United States.

40 ASEAN-5: Indonesia, Malaysia, Philippines, Singapore, and Thailand.
} 
based on Z-scores with greater than 4 and significant Mahalanobis $\mathrm{D}^{2}$, no record was eliminated. The final sample size was 340 .

\subsection{Descriptive Statistics}

The summary of the descriptive statistics of the variables is presented in Table 8. The results showed that the mean value of GCIOR was $27.22 \pm 23.26$, BR was $33.32 \pm, 28.37$, EE was $26.18 \pm 20.84$, and IS was $26.71 \pm$. 22.49. The summary statistics of the twelve-pillars were also included in the table.

Table 8: Descriptive statistics

\begin{tabular}{|c|c|c|c|c|}
\hline Variable & Mean & Std. Dev. & Min & Max \\
\hline GCIOR & 27.22 & 23.26 & 1 & 106 \\
\hline BR & 33.32 & 28.37 & 1 & 110 \\
\hline BRINS & 41.13 & 36.88 & 1 & 143 \\
\hline BRINF & 31.14 & 26.90 & 1 & 105 \\
\hline BRMEE & 46.57 & 35.46 & 1 & 138 \\
\hline BRHPE & 37.38 & 33.06 & 1 & 135 \\
\hline $\mathrm{EE}$ & 26.18 & 20.84 & 1 & 97 \\
\hline EEHET & 31.91 & 26.48 & 1 & 93 \\
\hline EEGME & 37.41 & 34.40 & 1 & 145 \\
\hline EELME & 49.56 & 42.27 & 1 & 144 \\
\hline EEFMD & 38.51 & 34.65 & 1 & 133 \\
\hline EETRD & 34.57 & 29.27 & 1 & 121 \\
\hline EEMAS & 24.20 & 22.94 & 1 & 130 \\
\hline IS & 26.71 & 22.49 & 1 & 108 \\
\hline ISBUS & 26.42 & 22.77 & 1 & 119 \\
\hline ISINN & 28.21 & 24.24 & 1 & 111 \\
\hline
\end{tabular}

Source: Author

\subsection{Panel data analysis}

This section employed country-year panel data. Initially, the proposed hypothesis were tested using the panel data regression analysis through models are shown below. Before attempting the analysis, the multicollinearity issue was tested. Due to the expected high multicollinearity among independent variables, the independent variables were not included in the regression analysis simultaneously. The variance inflation factor (VIF) values of the models ranges between 1.14 and 6.44 which are far below than the threshold value of 10 . As a result, there were no multicollinearity between the independent variables. The proposed models are listed below, the objective is to determine;

Model 1: $\mathrm{GCIOR}_{\mathrm{it}}=\beta_{0}+\beta_{1} \mathrm{BR}_{\mathrm{it}}+\beta_{2} \mathrm{EE}_{\mathrm{it}}+\beta_{3} \mathrm{IS}_{\mathrm{it}}+\varepsilon$

Model 2: $\mathrm{GCIOR}_{\mathrm{it}}=\beta_{0}+\beta_{1} \mathrm{BRINS}_{\mathrm{it}}+\beta_{2} \mathrm{BRINF}_{\mathrm{it}}+\beta_{3} \mathrm{BRMEE}_{\mathrm{it}}+\varepsilon$

Model 3: $\mathrm{GCIOR}_{\mathrm{it}}=\beta_{0}+\beta_{1} \mathrm{EEHET}_{\mathrm{it}}+\beta_{2} \mathrm{EEGME}_{\mathrm{it}}+\beta_{3} \mathrm{EELME}_{\mathrm{it}}+\beta_{4} \mathrm{EETRD}_{\mathrm{it}}+\beta_{5} \mathrm{EEMAS}_{\mathrm{it}}+\varepsilon$ 
Model 4: $\mathrm{GCIOR}_{\mathrm{it}}=\beta_{0}+\beta_{1} \mathrm{ISBUS}_{\mathrm{it}}+\beta_{2} \mathrm{ISINN}_{\mathrm{it}}+\varepsilon$

Table 9: Fixed -Effects model panel data analysis

\begin{tabular}{|c|c|c|c|c|}
\hline Independent variables & $\begin{array}{r}\text { Model } 1 \\
\text { GCIOR }\end{array}$ & $\begin{array}{r}\text { Model } 2 \\
\text { GCIOR }\end{array}$ & $\begin{array}{r}\text { Model } 3 \\
\text { GCIOR }\end{array}$ & $\begin{array}{r}\text { Model } 4 \\
\text { GCIOR }\end{array}$ \\
\hline BR & $\begin{array}{c}0.37^{* * *} \\
(16.90)\end{array}$ & & & \\
\hline $\mathrm{EE}$ & $\begin{array}{l}0.24^{* * *} \\
(7.66)\end{array}$ & & & \\
\hline IS & $\begin{array}{r}0.45^{* * *} \\
(17.12)\end{array}$ & & & \\
\hline BRINS & & $\begin{array}{c}0.34^{* * *} \\
(14.07)\end{array}$ & & \\
\hline BRINF & & $\begin{array}{l}0.25^{* * *} \\
(7.15)\end{array}$ & & \\
\hline BRMEE & & $\begin{array}{r}0.092^{* * *} \\
(7.75)\end{array}$ & & \\
\hline BRHPE & & $\begin{array}{l}0.12^{* * *} \\
(3.92)\end{array}$ & & \\
\hline EEHET & & & $\begin{array}{l}0.19^{* * *} \\
(4.91)\end{array}$ & \\
\hline EEGME & & & $\begin{array}{l}0.21^{* *} \\
(6.24)\end{array}$ & \\
\hline EELME & & & $\begin{array}{r}0.022 \\
(0.97)\end{array}$ & \\
\hline EEFMD & & & $\begin{array}{l}0.14^{* * *} \\
(6.55)\end{array}$ & \\
\hline EETRD & & & $\begin{array}{l}-0.018 \\
(-0.48)\end{array}$ & \\
\hline EEMAS & & & $\begin{array}{r}0.15 \\
(1.57)\end{array}$ & \\
\hline ISBUS & & & & $\begin{array}{r}0.45^{* * *} \\
(11.56)\end{array}$ \\
\hline ISINN & & & & $\begin{array}{c}0.30^{* * *} \\
(10.12)\end{array}$ \\
\hline Constant & $\begin{array}{l}-3.45^{* * *} \\
(-4.47)\end{array}$ & $\begin{array}{l}-3.50^{* *} \\
(-2.21)\end{array}$ & $\begin{array}{r}3.78 \\
(1.51)\end{array}$ & $\begin{array}{l}6.76^{* * *} \\
(7.62)\end{array}$ \\
\hline $\begin{array}{l}N \\
\text { Adj. } R^{2}\end{array}$ & $\begin{array}{r}340 \\
0.833\end{array}$ & $\begin{array}{r}340 \\
0.588\end{array}$ & $\begin{array}{r}340 \\
0.388\end{array}$ & $\begin{array}{r}340 \\
0.611\end{array}$ \\
\hline F-stat & $574.15^{* * *}$ & $130.03^{* * *}$ & $42.25^{* * *}$ & $283.57^{* * *}$ \\
\hline
\end{tabular}

t statistics in parentheses; ${ }^{*} p<0.10,{ }^{* *} p<0.05,{ }^{* * *} p<0.01$

Source: Author 
To start with, the pooled OLS and Fixed-Effects (FE) model were compared using F-test. The results indicated the FE model to be chosen (F-test = 23.03/df=33/303; p-value=0.001). In addition, in order to decide between fixed or random effects model, Hausman test was performed; the key test results showed that fixed effect model is the most appropriate compared to random effects model (Hausman test: $\chi^{2}(3)$ : 19.52, p-value: 0.001 ). To eliminate the first-order serial correlation in the estimation, fixed-effect panel analysis with a Cochrane-Orcutt procedure on the data was employed. The results illustrated in Table 9 show the fixed-effects model coefficients with their corresponding t-statistics.

The results indicated that BR, EE, and IS had a significant positive impact on GCIOR a 1\% significance level (Model 1). In addition, the effect of four-sub-dimensions of basic requirements, which are BRINS, BRINF, BRMEE, and EEHET, had a significant positive association with GCIOR at 1\% significance level (Model 2). In model 3, only EEHET, EEGME, and EEFMD have a significant positive impact on GCIOR while EELME and EETRD had no significant impact on GCIOR at 5\% significance level. Finally, the subdimension of IS (ISBUS and ISINN) were also significantly positively associated with GCIOR at 1\% significance level based on Model 4.

\subsection{Comparison Tests}

In order to investigate whether the gap between Turkey and the countries in G8, ASEAN-5, and G19 have widened or narrowed in terms of financial stability during 2009 - 2018, a comparison test was employed. In this analysis, the mean GCIOR values of Turkey were compared with those of G8, ASEAN5 and G19 countries using one-way ANOVA with Scheffe multiple-comparison test.

Table 10: GCIOR for G8 countries and Turkey during 2009 - 2018

\begin{tabular}{lrrrr}
\hline Country & Mean & Std. Dev. & Freq. & $\Delta$ (Turkey-G8) \\
\hline Turkey & 53.5 & 7.56 & 10 & - \\
Canada & 12.6 & 2.22 & 10 & $40.9^{* * *}$ \\
France & 19.7 & 3.13 & 10 & $33.8^{* * *}$ \\
Germany & 5.4 & 1.07 & 10 & $48.1^{* * *}$ \\
Italy & 45.8 & 3.01 & 10 & 7.7 \\
Japan & 8 & 1.49 & 10 & $45.5^{* * *}$ \\
Russian Federation & 55.3 & 10.68 & 10 & -1.8 \\
United Kingdom & 9.9 & 1.97 & 10 & $43.6^{* * *}$ \\
United States & 3.5 & 1.78 & 10 & $50^{* * *}$ \\
\hline
\end{tabular}

Source: Author; ${ }^{*} \mathrm{p}<.05 ;{ }^{* *} \mathrm{p}<.01 ;{ }^{* * *} \mathrm{p}<.001$ by ANOVA Scheffe multiple-comparison test

The mean GCIOR of Turkey was compared with G8 countries, the results are shown in Table 10. The one-way ANOVA analysis was performed in order to determine the significance of the differences 
between Turkey and G8 countries. The table shows the key results comprising the average, standard deviation and the mean difference between Turkey and the G8 countries of GCIOR. Based on the analysis, the results indicate that Turkey's mean GCIOR value is statistically significantly higher than those of Canada, Germany, France, Japan, and the United Kingdom ( $<$.001). Even though Turkey's mean GCIOR score is higher than that of Italy, the difference is not statistically significant ( $p>.05$ ). Finally, the mean GCIOR value of Russian Federation is a little bit higher than that of Turkey, however this difference is also not statistically significant $(\mathrm{p}>.05)$.

Table 11: GCIOR for ASEAN-5 countries and Turkey during 2009 - 2018

\begin{tabular}{lrrrr}
\hline Country & Mean & Std. Dev. & Freq. & $\Delta$ (Turkey-ASEAN5) \\
\hline Turkey & 53.5 & 7.56 & 10 & - \\
Indonesia & 43.5 & 7.58 & 10 & 10 \\
Malaysia & 22.7 & 2.58 & 10 & $30.8^{* * *}$ \\
Philippines & 65.4 & 13.71 & 10 & $-11.9^{* *}$ \\
Singapore & 2.6 & 0.97 & 10 & $50.9^{* * *}$ \\
Thailand & 35.1 & 2.88 & 10 & $18.4^{* * *}$ \\
\hline
\end{tabular}

Source: Author; ${ }^{*} \mathrm{p}<.05 ;^{* *} \mathrm{p}<.01{ }^{* * *} \mathrm{p}<.001$ by ANOVA Scheffe multiple-comparison test

Similarly, Table 11 shows the comparison test results of mean GCICOR based on one-way ANOVA between ASEAN-5 countries and Turkey. The results indicate that the mean GCIOR value of Turkey is statistically significantly higher those of Singapore, Malaysia, and Thailand at 1\% significance level. Furthermore, Philippines' mean GCIOR value is statistically significantly higher than that of Turkey at 5\% significance level. Although Turkey's mean GCIOR values are higher than that of Indonesia, but this difference is not statistically significant ( $p$-value $>.05$ ).

Finally, the mean GCIOR value of Turkey and G19 countries were compared using one -way ANOVA with Scheffe multiple - comparison test. The results were presented in Table 12, which indicate that the mean GCIOR of Turkey is statistically significantly higher than those of Australia, Canada, China, France, Germany, Japan, Korea Republic, Saudi Arabia, United Kingdom, and United States ( $p<0.01$ ) while mean GCIOR of Argentina is statistically significantly higher than that of Turkey $(\mathrm{p}<0.05)$. Even though the mean GCIOR of Turkey is higher than those of India, Indonesia, Italy, and South Africa, however the differences are not statistically significant $(\mathrm{p}>0.05)$. Similarly, even though the mean GCIOR of Brazil, Mexico, and Russian Federation are higher than that of Turkey, but the differences are not significant $(\mathrm{p}>0.05)$. For more detailed results of the analyses, see Figures 6, 7, and 8; plus more comprehensive tables with complete results are provided in the appendix. 


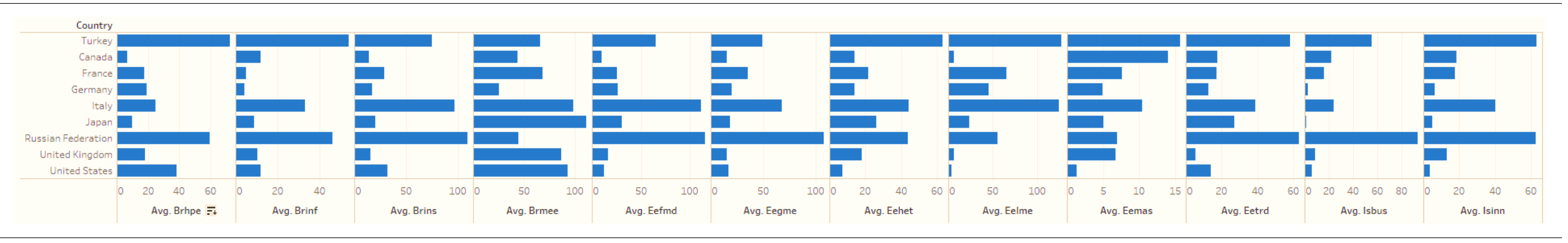

Figure 6: Turkey and G8

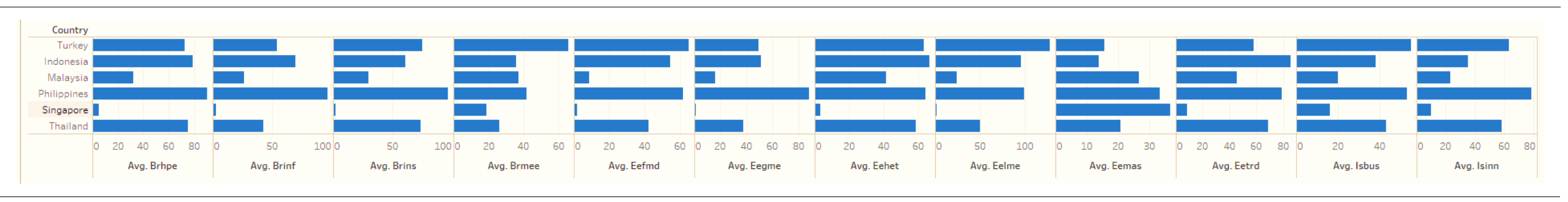

Figure 7: Turkey and ASEAN-5

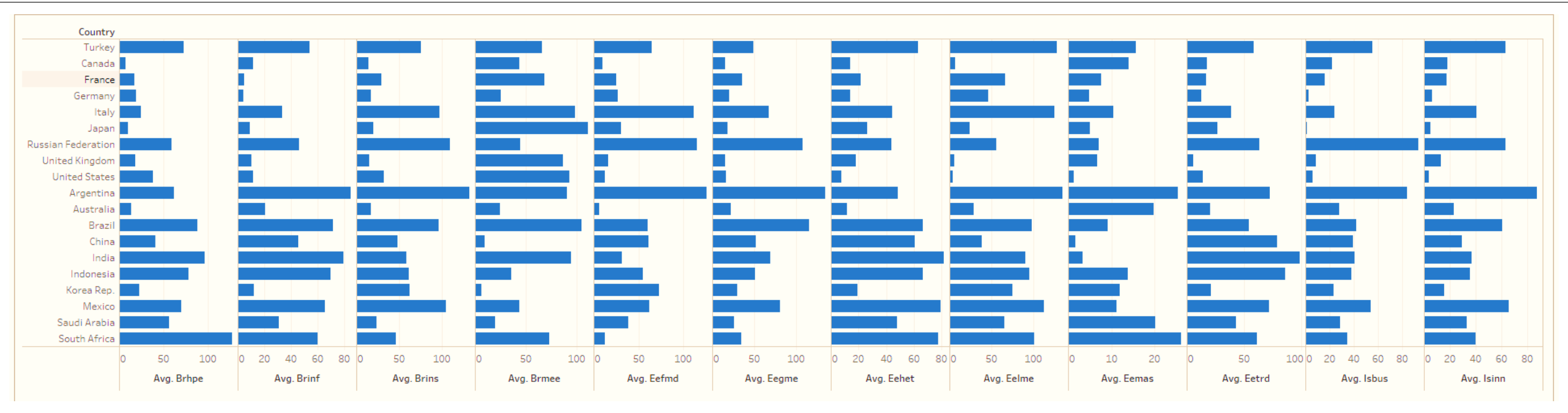

Figure 8: Turkey and G19 
Table 12: GCIOR for G19 countries and Turkey during 2009 - 2018

\begin{tabular}{lrrrr}
\hline Country & Mean & Std. Dev. & Freq. & $\Delta$ (Turkey-G19) \\
\hline Turkey & 53.5 & 7.56 & 10 & \\
Argentina & 94.9 & 8.74 & 10 & $-41.4^{* *}$ \\
Australia & 19.6 & 2.46 & 10 & $33.9^{* * *}$ \\
Brazil & 62.8 & 11.75 & 10 & -9.3 \\
Canada & 12.6 & 2.22 & 10 & $40.9^{* * *}$ \\
China & 28.1 & 1.2 & 10 & $25.4^{* * *}$ \\
France & 19.7 & 3.13 & 10 & $33.8^{* * *}$ \\
Germany & 5.4 & 1.07 & 10 & $48.1^{* * *}$ \\
India & 53 & 9.52 & 10 & 0.5 \\
Indonesia & 43.5 & 7.58 & 10 & 10 \\
Italy & 45.8 & 3.01 & 10 & 7.7 \\
Japan & 8 & 1.49 & 10 & $45.5^{* * *}$ \\
Korea Rep. & 22.6 & 4.38 & 10 & $30.9^{* * *}$ \\
Mexico & 57.2 & 4.8 & 10 & -3.7 \\
Russian Federation & 55.3 & 10.68 & 10 & -1.8 \\
Saudi Arabia & 23.9 & 4.68 & 10 & $29.6^{* * *}$ \\
South Africa & 51.2 & 5.07 & 10 & 2.3 \\
United Kingdom & 9.9 & 1.97 & 10 & $43.6^{* * *}$ \\
United States & 3.5 & 1.78 & 10 & $50^{* * *}$ \\
\hline
\end{tabular}

Source: Author; ${ }^{*} \mathrm{p}<.05 ;{ }^{* *} \mathrm{p}<.01 ;{ }^{* * *} \mathrm{p}<.001$ by ANOVA Scheffe multiple-comparison test

\subsection{Discussion and Concluding Remarks}

Since the day Mustafa Kemal created the Turkish Republic, Turkey has faced a constant inventory of instability-inflicting developments; military coup d'état in 1960 and 1980; military memorandum in 1971, 1997, and 2007 (i.e. the Turkish military put pressure on the ruling party instead of sending its tanks); alleged military coup in 1993 and the latest coup d'état attempt in July 2016 by a fraction of the Turkish military. When there were no coup d'état or military memorandums, there were cases associated with coup such as Sarıkız (Blonde Girl), Ayıșığı (Moonlight), Yakamoz (Phosphorescence) and Eldiven (Glove), Ergenekon trials (2008-16), and Operation Sledgehammer (a coup plan targeting the AKP - the ruling party that was founded in 2002). All of these episodes of instability not only had severe negative impact on the Turkish economy, but cost taxpayers billions of dollars. ${ }^{41}$

The period of 2002-07 (Table 13) was the best time for Turkey in terms of economic growth (over 7\%) and annual GDP per capita growth (over 21\%), attributable to (i) single party (non-coalition) AKP government; (ii) EU-accession negotiations (Table 12); and (iii) AKP's fruitful economic stimulus programs. Despite Turkey's large market size, weaknesses in quality of infrastructure and human resources base, and inefficient labor market have adversely affected Turkey's growth potential.

\footnotetext{
41 Since the early 1980s, the Turkish military has been fighting against the designated terrorist Kurdish militant and political organization called the Kurdistan Workers' Party (PKK), which was founded in 1974 by Abdullah Öcalan; since 1984, more than 40,000 people have been killed and over $\$ 100$ billion were spent.
} 
Table 13: Key dates and developments as Turkey's EU bid in limbo

\begin{tabular}{|c|c|}
\hline Key Dates & Key Developments \\
\hline September 1959 & Turkey applies for associate membership of the European Economic Community (EEC). \\
\hline September 1963 & $\begin{array}{l}\text { Signature of the Association Agreement, aiming at enhancing economic cooperation and } \\
\text { achieving a Customs Union between Turkey and the EEC. }\end{array}$ \\
\hline April 1987 & Turkey presents its formal application for membership of the European Economic Community. \\
\hline January 1995 & EU-Turkey Agreement creating a customs union. \\
\hline December 1999 & The European Council recognizes Turkey as a candidate country. \\
\hline December 2004 & The European Council agrees to start accession negotiations with Turkey. \\
\hline October 2005 & Start of accession negotiations. \\
\hline December 2006 & $\begin{array}{l}\text { The Council decides that eight negotiating chapters cannot be opened and no chapter can be } \\
\text { closed until Turkey meets its obligation of full, non-discriminatory implementation of the } \\
\text { additional protocol to the Association Agreement. }\end{array}$ \\
\hline May 2012 & European Commission and Turkey start the implementation of the Positive agenda for Turkey. \\
\hline December 2013 & $\begin{array}{l}\text { The EU-Turkey readmission agreement is signed in parallel with the launching of the visa } \\
\text { liberalization dialogue. }\end{array}$ \\
\hline October 2014 & The EU-Turkey readmission agreement enters into force. \\
\hline March 2015 & The European Commission and Turkey launch a high-level energy dialogue. \\
\hline May 2015 & $\begin{array}{l}\text { The European Commission and Turkey agree to modernize the } 20 \text {-year-old Customs Union } \\
\text { Agreement and to enhance EU-Turkey bilateral trade relations. }\end{array}$ \\
\hline November 2015 & $\begin{array}{l}\text { On the occasion of the EU-Turkey Leaders' Meeting, both sides agree on the activation of a Joint } \\
\text { Action Plan aiming at ending the irregular migration from Turkey to the EU, in full compliance } \\
\text { with EU and international standards. }\end{array}$ \\
\hline December 2015 & Chapter 17 on economic and monetary policy is opened. \\
\hline January 2016 & The EU-Turkey high-level political dialogue and high-level energy dialogue take place. \\
\hline March 2016 & $\begin{array}{l}\text { The EU and Turkey agree on a Joint Statement on the basis of the Joint Action Plan of November } \\
2015 .\end{array}$ \\
\hline April 2016 & $\begin{array}{l}\text { The first EU-Turkey high-level economic dialogue takes place; the first Report on the } \\
\text { implementation of the EU-Turkey Statement of } 18 \text { March } 2016 \text { is published. }\end{array}$ \\
\hline May 2016 & $\begin{array}{l}\text { The third Report on progress by Turkey in fulfilling the requirements of its visa liberalization } \\
\text { roadmap is published. }\end{array}$ \\
\hline June 2016 & Chapter 33 on financial and budgetary provisions is opened. \\
\hline September 2016 & The EU-Turkey high-level political dialogue takes place. \\
\hline December 2016 & $\begin{array}{l}\text { The European Commission adopts a recommendation for opening of negotiations with Turkey on } \\
\text { the modernization of the Customs Union. }\end{array}$ \\
\hline May 2017 & EU-Turkey Leaders' meeting takes place in Brussels. \\
\hline July 2017 & The EU-Turkey high-level political dialogue takes place. \\
\hline November 2017 & The first high-level EU-Turkey dialogue on transport takes place. \\
\hline December 2017 & The EU-Turkey high-level economic dialogue takes place. \\
\hline March 2018 & EU-Turkey Leaders' meeting takes place in Varna, Bulgaria. \\
\hline April 2018 & The 77th EU-Turkey Joint Parliamentary Committee takes place in Brussels. \\
\hline November 2018 & The EU-Turkey high-level political dialogue takes place in Ankara. \\
\hline December 2018 & The 78th EU-Turkey Joint Parliamentary Committee takes place in Ankara. \\
\hline January 2019 & The EU-Turkey high-level dialogue on transport takes place in Brussels. \\
\hline February 2019 & The EU-Turkey high-level economic dialogue takes place in Istanbul. \\
\hline March 2019 & The 54th EU-Turkey Association Council takes place in Brussels. \\
\hline
\end{tabular}

Source: European Commission; https://www.avrupa.info.tr/en/news/key-findings-2019-report-turkey-9579 
Unresolved issues of transparency and inefficiency of public institutions continue to have negative impact on Turkey's sovereign rating and future growth prospects. Geopolitical risks have risen for Turkey since President Recep Tayip Erdoğan walked off the stage at the 2009 Davos summit over clash in Gaza and accused Israel for engaging in inhumane treatment of Palestinians.

Table 14: GDP and GDP per capita annual growth

\begin{tabular}{r|r|r|r|r|r}
\hline Date & $\begin{array}{c}\text { Annual GDP } \\
\$ \text { million }\end{array}$ & $\begin{array}{c}\text { GDP Growth } \\
\%\end{array}$ & Date & $\begin{array}{c}\text { GDP Per Capita } \\
\$\end{array}$ & $\begin{array}{c}\text { GDP P.C. Annual } \\
\text { Growth \% }\end{array}$ \\
\hline 2007 & 675,010 & 5.0 & 2007 & 9,563 & 21.1 \\
\hline 2006 & 550,796 & 7.1 & 2006 & 7,899 & 8.5 \\
\hline 2005 & 501,163 & 9.0 & 2005 & 7,278 & 22.3 \\
\hline 2004 & 404,853 & 9.6 & 2004 & 5,953 & 28.2 \\
\hline 2003 & 311,944 & 5.6 & 2003 & 4,643 & 29.4 \\
\hline 2002 & 238,342 & 6.4 & 2002 & 3,589 & 17.6 \\
\hline
\end{tabular}

Source: Countryeconomy.com; https://countryeconomy.com/gdp/turkey

As shown in Table 15, Turkey has dropped by 10 places in the overall rankings, making it far below its historical highs (the country ranked 43rd in 2012-13). Since the 2016 failed coup attempt, there has been a substantial rise in public's distrust for government institutions which became increasingly authoritarian through dysfunctional politics and laws that have been purposely designed to suppress the citizens of Turkey. Furthermore, there has been a noticeable deterioration in democratic progress, attributable to negative developments in rule of law, human rights, and the Judiciary/legal system.

Table 15: Global Competitiveness Index overall rank

\begin{tabular}{l|r|r|r|r|r|r|r|r|r|r}
\hline \begin{tabular}{l} 
Turkey \& \\
\multicolumn{1}{c|}{ G8 }
\end{tabular} & $\begin{array}{r}2008 \\
2009\end{array}$ & 2009 & 2010 & 2011 & 2012 & 2013 & 2014 & 2015 & 2016 & 2017 \\
\hline Canada & 10 & 9 & 10 & 12 & 14 & 14 & 15 & 13 & 15 & 14 \\
\hline France & 16 & 16 & 15 & 18 & 21 & 23 & 23 & 22 & 21 & 22 \\
\hline Germany & 7 & 7 & 5 & 6 & 6 & 4 & 5 & 4 & 5 & 5 \\
\hline Italy & 49 & 48 & 48 & 43 & 42 & 49 & 49 & 43 & 44 & 43 \\
\hline Japan & 9 & 8 & 6 & 9 & 10 & 9 & 6 & 6 & 8 & 9 \\
\hline Russia & 51 & 63 & 63 & 66 & 67 & 64 & 53 & 45 & 43 & 38 \\
\hline UK & 12 & 13 & 12 & 10 & 8 & 10 & 9 & 10 & 7 & 8 \\
\hline US & 1 & 2 & 4 & 5 & 7 & 5 & 3 & 3 & 3 & 2 \\
\hline Turkey & 63 & 61 & 61 & 59 & 43 & 44 & 45 & 51 & 55 & 53 \\
\hline
\end{tabular}

Source: World Economic Forum (WEF); https://www.weforum.org/

When Turkey's Global Competitiveness Index overall rank (GCIOR) is compared with those of the G8 countries, it is only better than Russia but significantly worse than the G7 countries' rankings (Table 14). As far as individual rankings for 12 pillars are concerned, Turkey has achieved 13 th place out of 140 countries for market size which was its highest ranking, ranked 47th in innovation capability, 48th in health, and 50th in infrastructure; ranked 116th in macro-economic stability, it's worst (Figure 9). 


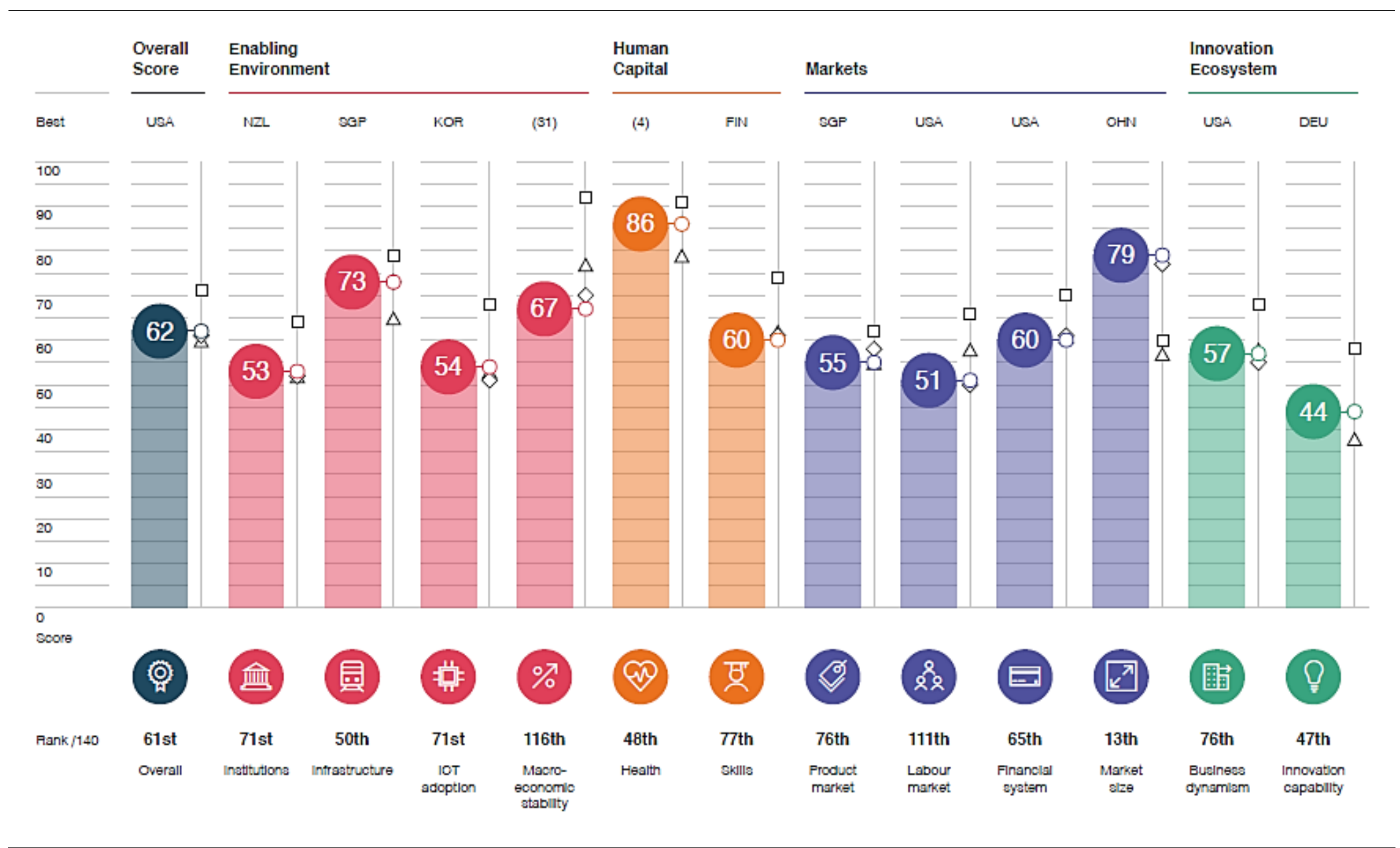

Source: World Economic Forum (WEF); https://www.weforum.org/

Figure 9: Turkey's global competitiveness rankings in 12 pillars 
Economic and democratic progress and related developments are interlinked; therefore, advanced nations have made more progress in democracy than poor, developing, and emerging economies. We have made the following conclusions regarding Turkey's backslide on competitiveness which directly or indirectly have contributed to Turkey's backslide on democracy and its EU accession negotiations (Table 13).

Table 16: Areas affecting Turkey's global competitiveness

\begin{tabular}{|c|c|}
\hline Year/Rank & Negative Developments Affecting Turkey's Economic and Democratic Progress \\
\hline $\begin{array}{c}\text { 2008-09 } \\
63 \mathrm{rd}\end{array}$ & $\begin{array}{l}\text { Turkey's global competitiveness was hindered by weaknesses in infrastructure, primary education, } \\
\text { health care, skilled workforce, and transparency of public institutions. Due to the ruling party's } \\
\text { (AKP) increasing dictatorial/authoritarian rule and dysfunctional policies, There has been a } \\
\text { significant decrease in public trust for the government. Growing concerns over financial market } \\
\text { efficiency and soundness of banks contributed to Turkey's drop by } 10 \text { places in the rankings. }\end{array}$ \\
\hline $\begin{array}{c}\text { 2009-10 } \\
61 \text { st }\end{array}$ & $\begin{array}{l}\text { Turkey's large market has benefited from strong competition and business-friendly practices } \\
\text { which were underpinned by macroeconomic stability following the } 2008 \text { global financial crisis. } \\
\text { However ranked 120th in efficient labor market (in this case, inefficient labor market). }\end{array}$ \\
\hline $\begin{array}{c}\text { 2010-11 } \\
61 \text { st }\end{array}$ & $\begin{array}{l}\text { The Turkish economy benefited from intense local competition (15th); the infrastructure (roads, } \\
\text { ports, and railroads) was improved but still needed major upgrading (ranked 56th). Inefficiencies } \\
\text { in the labor market (127th) and transparency of public entities worsened considerably. }\end{array}$ \\
\hline $\begin{array}{c}\text { 2011-12 } \\
59 \text { th }\end{array}$ & $\begin{array}{l}\text { Again thanks to large market (17th) and strong local competition (13th), Turkey moved up } 2 \text { places } \\
\text { in the rankings. However, labor market conditions (133rd), transparency of public entities ( } 86 \text { th), } \\
\text { healthcare ( } 75 \text { th), higher education and training continue to affect competitiveness negatively. }\end{array}$ \\
\hline $\begin{array}{c}2012-13 \\
43 \mathrm{rd}\end{array}$ & $\begin{array}{l}\text { Turkey made the biggest leap in the rankings, moved up by } 16 \text { places from the previous year, this } \\
\text { was largely attributable to Turkey's GDP growth in } 2011 \text { ( } 8.4 \%) \text { and favorable macroeconomic } \\
\text { environment. Although there was a noticeable improvement in the transparency of public entities } \\
\text { (67th), the labor market inefficiencies (124th) remained to be a bottleneck. }\end{array}$ \\
\hline $\begin{array}{c}\text { 2013-14 } \\
44 \text { th }\end{array}$ & $\begin{array}{l}\text { Turkey fell by one spot from its highest ranking last year owing to exogenous (macroeconomic } \\
\text { instability) and endogenous (rising fiscal deficit and inflation) factors. Excluding the efficiency of } \\
\text { the labor market (130th), transparency (58th) and Infrastructure (49th) improved further ( } 49 \text { th) }\end{array}$ \\
\hline $\begin{array}{c}\text { 2014-15 } \\
45 \text { th }\end{array}$ & $\begin{array}{l}\text { Turkey dropped one more place to } 45 \text { th in the rankings out of } 140 \text { countries. After GDP and GDP } \\
\text { per capita peaked in } 2013 \text { ( } \$ 950.3 \text { billion and } \$ 12,395 \text { respectively), the Turkish economy has lost } \\
\text { steam since then due to substantially risen geopolitical risks. Also in } 2013 \text {, Turkey achieved the } \\
\text { highest global competitiveness ranking of } 43 \text { rd (also see Figure } 10 \text { ). }\end{array}$ \\
\hline $\begin{array}{c}2015-16 \\
51 s t\end{array}$ & $\begin{array}{l}\text { Augmented geopolitical risks and the strained US-Turkey relations caused the country to drop six } \\
\text { positions to 51st; moreover, a general decline in all } 12 \text { pillars was observed. Following the June } \\
2015 \text { elections, political conflict increased. Although the transportation infrastructure ( } 23 \mathrm{rd} \text { ) and } \\
\text { goods market efficiency ( } 45 \text { th) improved, labor market inefficiency remained very high (127th). }\end{array}$ \\
\hline $\begin{array}{c}\text { 2016-17 } \\
55 \text { th }\end{array}$ & $\begin{array}{l}\text { Turkey underwent another military coup on July } 15,2016 \text {, but this time it ended up as a failed } \\
\text { attempt by a fraction of the Turkish military; however, the data was collected before the event. } \\
\text { About } 4 \text { million refugees from Syria put pressure on the Turkish economy (i.e. the government } \\
\text { claims to have spent circa } \$ 50 \text { billion). Week domestic competition, lack of structural reforms, and } \\
\text { persistent inefficiencies in the labor market (126th) played a role in the drop of four places. }\end{array}$ \\
\hline $\begin{array}{c}\text { 2017-18 } \\
53 \mathrm{rd}\end{array}$ & $\begin{array}{l}\text { Turkey moves up two places, but still lower than its historic high ranking of } 43 \text { rd in } 2013 \text {. Turkey } \\
\text { leads many countries in the adoption of latest technologies, broadband (high-speed internet) } \\
\text { subscription has increased from } 50 \% \text { of the population to about } 70 \% \text { (i.e. more than } 50 \text { million). }\end{array}$ \\
\hline
\end{tabular}

Source: World Economic Forum (WEF); https://www.weforum.org/ 

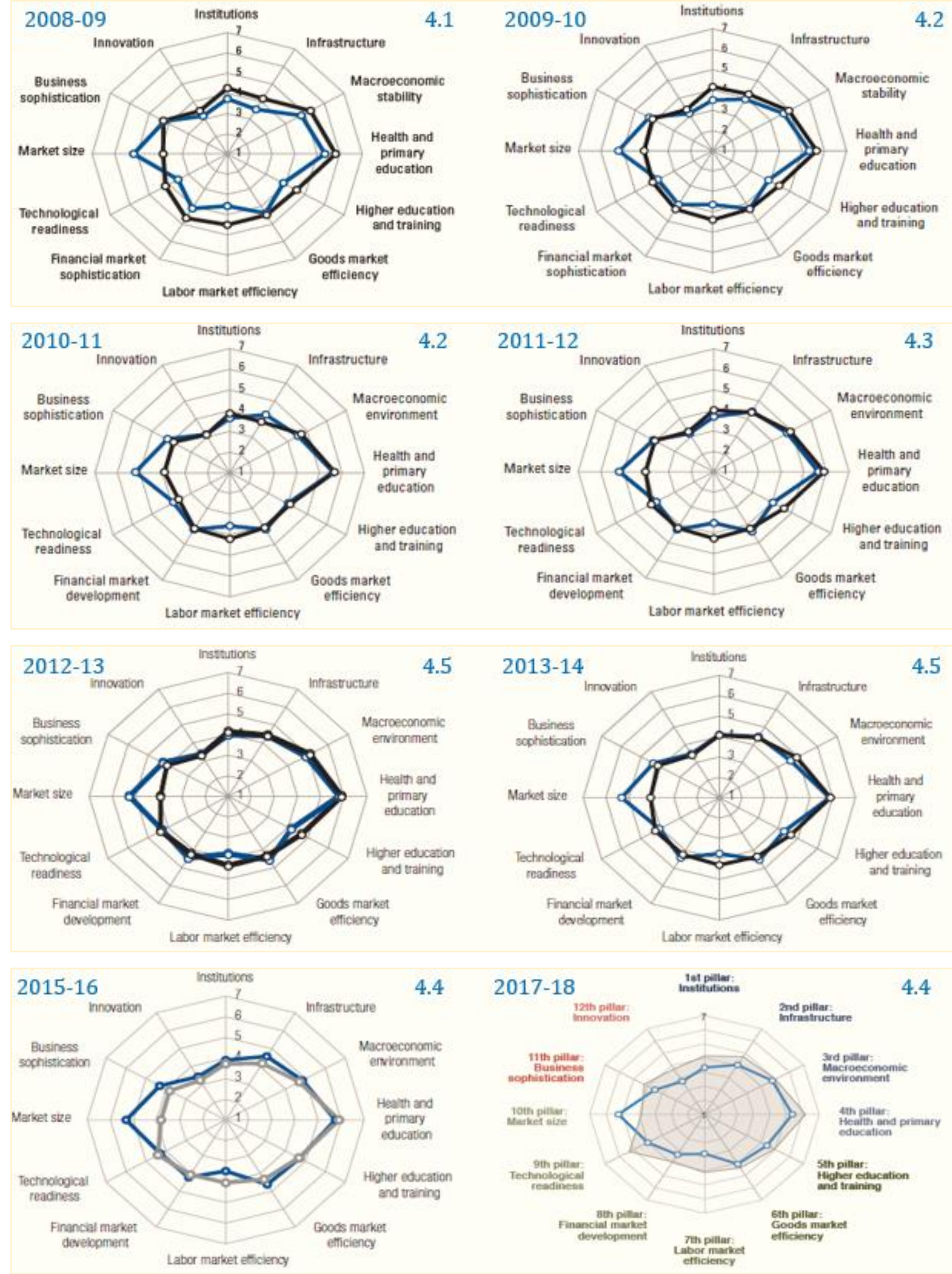

Source: World Economic Forum (WEF); https://www.weforum.org/

Figure 10: Turkey's global competitiveness overall rankings (2008-2018) 


\section{References}

Ahmad, F. (1993). The Making of Modern Turkey. Routledge.

Akın, R. (2002). Türkiye'de Çok Partili Siyasi Hayat Geçiş Ve Demokrat Parti Yılları (1945-1960), Türkler Ansiklopedisi, 16. Cilt, Yeni Türkiye Yayınları, Ankara, ss. 911-922.

Aksakal, M. (2008). The Ottoman Road to War in 1914. The Ottoman Empire and the First World War. Cambridge University Press, Cambridge.

Aksan, V. (2007). Ottoman Wars 1700-1870: An Empire Besieged. London, NY: Pearson Longman.

Albayrak, M. (2004). Türk Siyasi Tarihinde Demokrat Parti (1946-1960). Phoenix Yayınevi, Ankara.

Altug, S., Filiztekin, A. \& Pamuk, S. (2008). Sources of Long-Term Economic Growth for Turkey, 18802005. European Review of Economic History, 12, 393-430. European Historical Economics Society, doi: 10.1017/S1361491608002293 Printed in the United Kingdom.

Anderson, 0. (1964). Great Britain and the Beginnings of the Ottoman Public Debt, 1854-55. The Historical Journal, VII, I, pp. 47-63. Printed in Great Britain.

Barkey, K. (2008). Empire of Difference: The Ottomans in Comparative Perspective. 357pages.

Bas, M. A. \& Stone, R. W. (2010). If Life Sends You Lemons: Adverse Selection and Growth under IMF Programs. University of Rochester.

Bird, G., Hussain, M. \& Joyce, J. P. (2004). Many Happy Returns? Recidivism and the IMF. Journal of International Money and Finance 23, No. 2, 231-251.

Birdal, M. (2010). The Political Economy of Ottoman Public Debt. Insolvency and European Financial Control in the Late Nineteenth Century. Tauris Academic Studies, London and New York.

Blaisdell, D.C. (1929). European Financial Control in the Ottoman Empire. A Study of the Establishment, Activities and Significance of the Administration of the Ottoman Public Debt. Columbia University Press, New York.

Boratav, K. (2009). Türkiye İktisat Tarihi 1908-2007. Ankara: Imge Kitabevi.

Caillard, V. (1894). The Ottoman Public Debt, Special Report on the Ottoman Public Debt for the Twelfth Financial Period (13th March, 1893, to 12th March, 1894), followed by the Translation of the Annual Report for the same Year of the Council of Administration, September. London.

Caillard, V. (1885). The Truth About Turkish Finances. Fortnightly Review September.

Çakır, C. (2001). Tanzimat Dönemi Osmanlı Maliyesi (Ottoman finance in Tanzimat Era), Küre Yayınları, Istanbul.

Conte, G. (2014). Regaining Control over Finance: The Ottoman Empire at the Eve of the World War I

Conway, P. (2007). The Revolving Door: Duration and Recidivism in IMF Programs. Review of Economics and Statistics 89, no. 2 (2007): 205-220.

Eken, S. \& Schadler, S. (2012). Turkey 2000-2010: A Decade of Transition Discussions among Experts. Istanbul, DEIKK Publications, November, http://en.deik.org.tr/Contents/FileAction/3130.

Eldem, E. (2005). Ottoman Financial Integration with Europe: Foreign Loans, the Ottoman Bank and the Ottoman Public Debt. European Review, 13:3, 431-445.

Eldem, V. (1994). Harp ve Mutakere Yillarinda Osmanli Imparatorlugu'nun Ekonomisi, Ankara: Turk Tarih Kurumu. 
Findley, C.V. (1986). Economic Bases of Revolution and Repression in the Late Ottoman Empire. Comparative Studies in Society and History 28(1): 81-106.

Findley, C.V. (2004). The Turks in World History. Oxford University Press, October. ISBN 0-19517726-6.

Guran, T. (2003). Osmanlı Mali Istatistikleri Bütçeler 1841-1918 (Ottoman Fiscal Statistics in 18411918), DĐE Yayınları, Ankara.

Harris, G. (1965). The Role of the Military in Turkish Politics. Middle East Journal, XIX.

Hulkiender, H. (2003). Bir Galata Bankeri'nin Portresi: 1806-1884. İstanbul: Osmanlı Bankası Arşiv Araștırma Merkezi.

Inalcik, H. \& Quataert, D. (1995). An Economic and Social History of the Ottoman Empire, 1300-1914. 1995. 1026 pages.

Ismihan, M., Metin-Ozcan, K. \& Tansel A. (2005). The Role of Macroeconomic Instability in Public and Private Capital Accumulation and Growth: The case of Turkey 1963-1999. Applied Economics, 37,2 , pp. 239-251.

Jackson, P. (2002). Review: The History of the Seljuq Turkmens: The History of the Seljuq Turkmens. Journal of Islamic Studies. Oxford Centre for Islamic Studies. 13(1): 75-76. doi:10.1093/jis/13.1.75.

Joyce, J.P. (2006). Promises Made, Promises Broken: A Model of IMF Program Implementation. Economics and Politics 18, no. 3 (2006): 339-365.

Karpat, K. (1959). Turkey's Politics: the Transition to a Multi-Party System. Princeton, NJ.

Kazgan, H. (1991). Galata Bankerleri. İstanbul: TEB Yayıncılık.

Kedourie, S. (1989). Turkey Before and After Ataturk: Internal and External Affairs. 282 pages.

Keynes, J. M. (1936). The General Theory of Employment, Interest, and Money. Macmillan, London.

Kibritçioğlu, A. (2001). Türkiye'de Ekonomik Krizler ve Hükümetler, 1969-2001. Yeni Türkiye Dergisi, 41, 174-190.

Kinross, P. (1977). The Ottoman Centuries: The Rise and Fall of the Turkish Empire. ISBN 0-68803093-9.

Kıray, E. (1995). Osmanlı'da Ekonomik Yapı ve Dıs Borçlar, (Economic Structure of Ottoman and External Debts). Iletisim Yayınları Đstanbul.

Kunt, M. \& Woodhead, C. (1995). Süleyman the Magnificent and His Age: The Ottoman Empire in the Early Modern World. 218 pages.

Lipovsky, I. (1991). The legal socialist parties of Turkey, 1960-1980. Middle Eastern Studies. January. Mango, A. (2000). Ataturk: The Biography of the Founder of Modern Turkey. ISBN 1-58567-011-1.

Marois, T. \& Güngen, A.R. (2016). Credibility and Class in the Evolution of Public Banks: The Case of Turkey. The Journal of Peasant Studies. 43 (6): 1285-1309, doi:10.1080/03066150.2016.1176023.

Nas, T.F. (1992). Economics and Politics of Turkish Liberalization. Lehigh University Press. ISBN 9780-934223-19-5.

Nas, T.F. (2008). Tracing the Economic Transformation of Turkey from the 1920s to EU Accession. Leiden: Martinus Nijhoff Publishers. 
Önis, Z. (2009). Beyond the 2001 Financial Crisis: The Political Economy of the New Phase of NeoLiberal Restructuring in Turkey. Review of International Political Economy 16(3) pp. 409-432.

Özbudun, E. (1976). Social Change and Political Participation in Turkey. Princeton, NJ.

Pamuk, Ș. (1987). The Ottoman Empire and European Capitalism, 1820-1913. London, New York, Melbourne: Cambridge University Press.

Raina, L. \& Bakker, M.R. (2003). A World Bank Country Study Report: Non-Bank Financial Institutions and Capital Markets in Turkey. World Bank, Washington, D.C. April 2003.

Rodkey, F.S. (1930). Lord Palmerston and the Rejuvenation of Turkey, 1830-41. Journal of Modern History, II (June 1930), 219.

Rustow, D. (1957). Politics and Islam in Turkey 1920-1935. In R.N. Frye, (ed.), Islam and the West. The Hague.

Rustow, D. (1987). Turkey: America's Forgotten Ally, New York, Council on Foreign Relations, 88-89.

Schick, I. C. \& Tonak, A. (1987). Turkey in Transition. New York.

Schaller, D. J. \& Zimmerer, J. (2008). Late Ottoman Genocides: The Dissolution of the Ottoman Empire and Young Turkish Population and Extermination Policies - Introduction. Journal of Genocide Research 10 (1): 7-14. doi:10.1080/14623520801950820.

Shaw, S. J. \& Shaw, E. K. (1977). History of the Ottoman Empire and Modern Turkey. Vol. 2, Reform, Revolution, and Republic: The Rise of Modern Turkey, 1808-1975. ISBN 0-521-29163-1.

Singer, M. (1977). The Economic Advance of Turkey, 1938-1960. Ankara.

Szyliowicz, J.S. (1966). Political Change in Rural Turkey: Erdemli. The Hague.

Taskinsoy, J. (2012a). Relevancy of Corporate Financial Policies and the Profit Maximization View of Islamic Banks. Journal of Social and Development Sciences, Vol. 3(6), pp. 184-193, June, ISSN 2221-1152.

Taskinsoy, J. (2012b). The Investment Rate of Return (IRR) to Tertiary Education in Turkey. Journal of Education and Vocational Research, Vol. 3(5), pp. 154-164, May, ISSN 2221-2590.

Taskinsoy, J. (2012c). The Return of Investment on Tertiary Education in Malaysia. Journal of Education and Vocational Research, Vol. 3(6), pp. 183-192, ISSN 2221-2590.

Taskinsoy, J. (2013a). Rigorous Capital Requirements under Basel III: Possible impact on Turkey's financial sector. Journal of WEI Business and Economics, Vol. 2(1), pp. 1-30, April.

Taskinsoy, J. (2013b). Basel III: Road to Resilient Banking, Impact on Turkey's Financial Sector. LAP LAMBERT Academic Publishing, 237 pages, ISBN 13: 978-3-659-30696-9.

Taskinsoy, J. (2013c). Economic \& Ecological Implications of Hydraulic Fracturing. West East Journal of Social Sciences, Vol. 2(1), pp. 11-39, April.

Taskinsoy, J. (2018a). Bitcoin Mania: An End to the US Dollar's Hegemony or another Cryptocurrency Experiment Destined to Fail? (December 1, 2018). Available at SSRN: https://ssrn.com/abstract=3311989 or http://dx.doi.org/10.2139/ssrn.3311989.

Taskinsoy, J. (2018b). Effects of Basel III Higher Capital and Liquidity Requirements on Banking Sectors across the Main South East Asian Nations. International Journal of Scientific \& Engineering Research (IJSER), Vol. 9(4), pp. 214-37, April, ISSN 2229-5518.

Taskinsoy, J. (2018c). The Cost Impact of Basel III across ASEAN-5: Macro Stress Testing of Malaysia's Banking Sector. LAP LAMBERT Academic Publishing, 369 pages, ISBN-13 978-613-9-90012-1. 
Taskinsoy, J. (2018d). A Macro Stress Testing Framework for Assessing Financial Stability: Evidence from Malaysia. Journal of Accounting, Finance and Auditing Studies (JAFAS), Vol. 4(3), July, ISSN 2149-0996

Taskinsoy, J. (2019a). Ever More Financial Instability notwithstanding the Basel Standards and the IMF's Financial Sector Assessment Program (February 4, 2019). Available at SSRN: https://ssrn.com/abstract=3328473 or http://dx.doi.org/10.2139/ssrn.3328473.

Taskinsoy, J. (2019b). Turkish Lira - A Fiat Currency that Resembles the Volatility of Cryptocurrencies: The Effects of Exchange Rate Volatility on Turkish Economy (February 15, 2019). Available at SSRN: https://ssrn.com/abstract=3335545 or http://dx.doi.org/10.2139/ssrn.3335545.

Taskinsoy, J. (2019c). The Transition from Barter Trade to Impediments of the Dollar System: One Nation, One Currency, One Monopoly (March 6, 2019). Available at SSRN: https://ssrn.com/abstract=3348119 or http://dx.doi.org/10.2139/ssrn.3348119

Taskinsoy, J. (2019d). Stress Testing Made Easy: No More US Banks Stumbling and Facing Public Embarrassment Due to the Federal Reserve's Qualitative Objection (March 17, 2019). Available at SSRN: https://ssrn.com/abstract=3354018 or http://dx.doi.org/10.2139/ssrn.3354018.

Taskinsoy, J. (2019e). Typology of Stress Testing: Microprudential vs. Macroprudential Stress Testing of Risk Exposures (March 28, 2019). Available at SSRN: https://ssrn.com/abstract=3361528 or http://dx.doi.org/10.2139/ssrn.3361528.

Taskinsoy, J. (2019f). Pure Gold for Economic Freedom: A Supranational Medium of Exchange to End American Monetary Hegemony as the World's Main Reserve Currency (April 25, 2019). Available at SSRN: https://ssrn.com/abstract=3377904 or http://dx.doi.org/10.2139/ssrn.3377904.

Taskinsoy, J. (2019g). Asian Miracle, Asian Tiger, or Asian Myth? Financial Sector and Risk Assessment through FSAP Experience: Enhancing Bank Supervision in Thailand (May 9, 2019). Available at SSRN: https://ssrn.com/abstract=3385337 or http://dx.doi.org/10.2139/ssrn.3385337.

Taskinsoy, J. (2019h). Higher Capital and Liquidity Regulations of Basel Standards Have Made Banks and Banking Systems Become More Prone to Financial and Economic Crises (June 9, 2019).

Available at SSRN: https://ssrn.com/abstract=3401378 or http://dx.doi.org/10.2139/ssrn.3401378.

Taskinsoy, J. (2019i). A Delicate Moment in Turkey's Economic Transition: Can Turkey Survive Mounting Economic Problems without the IMF's Bailout Package? (June 22, 2019). Available at SSRN: https://ssrn.com/abstract=3408520 or http://dx.doi.org/10.2139/ssrn.3408520.

Taskinsoy, J. (2019j). We Need No Dime from the IMF: Is This a Temporary Illusion or Can the Turkish Economy Recover from the Current Recession without the IMF Loans? (July 9, 2019). Available at SSRN: https://ssrn.com/abstract=3417431 or http://dx.doi.org/10.2139/ssrn.3417431.

Taskinsoy, J. (2019k). Facebook's Project Libra: Will Libra Sputter Out or Spur Central Banks to Introduce Their Own Unique Cryptocurrency Projects? (July 20, 2019). Available at SSRN: https://ssrn.com/abstract=3423453 or http://dx.doi.org/10.2139/ssrn.3423453.

Taskinsoy, J. (2019l). Is Facebook's Libra Project Already a Miscarriage? (August 15, 2019). Available at SSRN: https://ssrn.com/abstract=3437857 or http://dx.doi.org/10.2139/ssrn.3437857.

Taskinsoy, J. (2019m). Facebook’s Libra: Big Bang or Big Crunch? A Technical Perspective and Challenges for Cryptocurrencies (August 29, 2019). Available at SSRN: https://ssrn.com/abstract=3445150 or http://dx.doi.org/10.2139/ssrn.3445150. 
Taskinsoy, J. (2019n). Turkey's Unravelling Economy Resembles the Ottoman Empire's Financial Collapse (September 29, 2019). Available at SSRN: https://ssrn.com/abstract=3461216 or http://dx.doi.org/10.2139/ssrn.

Taskinsoy, J. (2019o). A Hiccup in Turkey's Prolonged Credit Fueled Economic Transition: A Comparative Analysis of Before and After the August Rout. Journal of Accounting, Finance and Auditing Studies (JAFAS), Vol. 5(4), October, ISSN 2149-0996. Doi: 10.32602/jafas.2019.37.

Taskinsoy, J. (2019p). This Time Is Different: Facebook's Libra Can Improve Both Financial Inclusion and Global Financial Stability as a Viable Alternative Currency to the U.S. Dollar. Journal of Accounting, Finance and Auditing Studies (JAFAS), Vol. 5(4), October, ISSN 2149-0996. Doi: 10.32602/jafas.2019.38.

Taskinsoy, J. (2019q). Blockchain: A Misunderstood Digital Revolution. Things You Need to Know about Blockchain (October 8, 2019). Available at SSRN: https://ssrn.com/abstract=3466480 or http://dx.doi.org/10.2139/ssrn.3466480.

Taskinsoy, J. (2019r). Blockchain: Moving Beyond Bitcoin into a Digitalized World (October 17, 2019). Available at SSRN: https://ssrn.com/abstract $=3471413$ or http://dx.doi.org/10.2139/ssrn.3471413.

Taskinsoy, J. (2019s). Blockchain: An Unorthodox Solution to Reduce Global Warming (October 24, 2019). Available at SSRN: https://ssrn.com/abstract=3475144 or http://dx.doi.org/10.2139/ssrn.3475144.

Taskinsoy, J. (2019t). Bitcoin and Turkey: A Good Match or a Perfect Storm? (October 30, 2019). Available at SSRN: https://ssrn.com/abstract=3477849 or http://dx.doi.org/10.2139/ssrn.3477849

Taskinsoy, J. (2019u). Facebook's Libra: Why Does US Government Fear Price Stable Cryptocurrency? (November 7, 2019). Available at SSRN: https://ssrn.com/abstract=3482441 or http://dx.doi.org/10.2139/ssrn.3482441.

Taskinsoy, J. (2019v). Global Cooling through Blockchain to Avoid Catastrophic Climate Changes by 2050 (November 29, 2019). Available at SSRN: https://ssrn.com/abstract=3495674 or http://dx.doi.org/10.2139/ssrn.3495674.

Taskinsoy, J. (2019w). The Global Competitiveness Index: A Comparative Analysis between Turkey and G8 Nations (December 8, 2019). Available at SSRN: https://ssrn.com/abstract=3500542 or http://dx.doi.org/10.2139/ssrn.3500542.

Taskinsoy, J. (2019x). Bitcoin: The Longest Running Mania - Tulips of the 21st Century? (December 18, 2019). Available at SSRN: https://ssrn.com/abstract=3505953 or http://dx.doi.org/10.2139/ssrn.3505953.

Taskinsoy, J. (2019y). Widening Development Gaps between ASEAN-5 and Advanced Nations (December 30, 2019). Available at SSRN: https://ssrn.com/abstract=3511482 or http://dx.doi.org/10.2139/ssrn.3511482.

Taskinsoy, J. (2020a). Malaysia: 'Crouching Tiger, Hidden Dragon' (January 19, 2020). Available at SSRN: https://ssrn.com/abstract=3522206 or http://dx.doi.org/10.2139/ssrn.3522206.

Taskinsoy, J. (2020b). No Brainer, Tackle Climate Change by 2030 or Await the Doomsday by 2100 (February 5, 2020). Available at SSRN: https://ssrn.com/abstract=3532709 or http://dx.doi.org/10.2139/ssrn.3532709. 
Taskinsoy, J. (2020c). From Primitive Barter to Inflationary Dollar: A Warless Economic Weapon of Mass Destruction (February 21, 2020). Available at SSRN: https://ssrn.com/abstract=3542145 or http://dx.doi.org/10.2139/ssrn.3542145.

Taskinsoy, J. (2020d). Stress Testing: A Measure of Financial Stability across ASEAN-5 (February 25, 2020). Available at SSRN: https://ssrn.com/abstract=3543955 or http://dx.doi.org/10.2139/ssrn.3543955.

Taskinsoy, J. (2020e). Diminishing Dollar Hegemony: What Wars and Sanctions Failed to Accomplish, COVID-19 Has (April 7, 2020). Available at SSRN: https://ssrn.com/abstract $=3570910$ or http://dx.doi.org/10.2139/ssrn.3570910.

Taskinsoy, J. (2020f). Old and New Methods of Risk Measurements for Financial Stability amid the Great Outbreak (April 27, 2020). Available at SSRN: https://ssrn.com/abstract $=3587150$ or http://dx.doi.org/10.2139/ssrn.3587150.

Taskinsoy, J. (2020g). COVID-19: Is the Great Outbreak a Sign of What the Future Has Stowed for the Human Race? (May 10, 2020). Available at SSRN: https://ssrn.com/abstract=3597434 or http://dx.doi.org/10.2139/ssrn.3597434.

Taskinsoy, J. (2020h). Cost Implications of the Great Lockdown due to the Novel Coronavirus Outbreak (May 18, 2020). Available at SSRN: https://ssrn.com/abstract=3604573 or http://dx.doi.org/10.2139/ssrn.3604573.

Taskinsoy, J. (2020i). Coronavirus Pandemic: The U.S. Induced Great Panic of the 21st Century (May 26, 2020). Available at SSRN: https://ssrn.com/abstract $=3610749$ or http://dx.doi.org/10.2139/ssrn.3610749.

Taskinsoy, J. (2020j). COVID-19 Could Cause Bigger Cracks in Turkey's Fragile Crisis Prone Economy (May 28, 2020). Available at SSRN: https://ssrn.com/abstract=3613367 or http://dx.doi.org/10.2139/ssrn.3613367.

Webster, D. (1939). The Turkey of Atatürk: Social Process in the Turkish Reformation. Philadelphia.

Weiker, W. (1975). Political Tutelage and Democracy in Turkey: the Free Party and Its Aftermath. Leiden.

Wendt, A. (1992). Anarchy is What States Make of it: Social Construction of Power Politics. International Organization, Vol. 46, No. 2, Spring 1992, pp. 391-425.

Wimmel, A. (2006). Beyond the Bosphorus? Comparing German, French and British Discourses on Turkey's Application to Join the European Union. Reihe Politikwissenschaft/Political Science Series, No. 111.

Yeldan, E. (2001). On the IMF-Directed Disinflation Program in Turkey: A Program for Stabilization and Austerity or a Recipe for Impoverishment and Financial Chaos? Ankara: Bilkent University.

Zurcher, E. J. (2004). Turkey: A Modern History (3rd ed.). 


\section{Appendix}

All the data contained in the Tables and Figures have been extracted from the Global Competitiveness Index (GCI) reports published annually by the World Economic Forum (WEF).

Table A1: Turkey compared with G8 countries

\begin{tabular}{|c|c|c|c|c|c|c|c|c|c|c|c|c|c|}
\hline Country & Year & Brhpe & Brinf & Brins & Brmee & Eefmd & Eegme & Eehet & Eelme & Eemas & Eetrd & Isbus & Isinn \\
\hline Turkey & 2008 & 78 & 66 & 80 & 79 & 76 & 55 & 72 & 125 & 15 & 58 & 60 & 66 \\
\hline Turkey & 2009 & 74 & 62 & 96 & 64 & 80 & 56 & 73 & 120 & 15 & 54 & 52 & 69 \\
\hline Turkey & 2010 & 72 & 56 & 88 & 83 & 61 & 59 & 71 & 127 & 16 & 56 & 52 & 67 \\
\hline Turkey & 2011 & 75 & 51 & 80 & 69 & 55 & 47 & 74 & 133 & 17 & 55 & 58 & 69 \\
\hline Turkey & 2012 & 63 & 51 & 64 & 55 & 44 & 38 & 74 & 124 & 15 & 53 & 47 & 55 \\
\hline Turkey & 2013 & 59 & 49 & 56 & 76 & 51 & 43 & 65 & 130 & 16 & 58 & 43 & 50 \\
\hline Turkey & 2015 & 73 & 53 & 75 & 68 & 64 & 45 & 55 & 127 & 16 & 64 & 58 & 60 \\
\hline Turkey & 2016 & 79 & 48 & 74 & 54 & 82 & 52 & 50 & 126 & 17 & 67 & 65 & 71 \\
\hline Turkey & 2017 & 84 & 53 & 71 & 50 & 80 & 53 & 48 & 127 & 14 & 62 & 67 & 69 \\
\hline Canada & 2008 & 6 & 6 & 15 & 43 & 10 & 16 & 9 & 7 & 14 & 9 & 18 & 13 \\
\hline Canada & 2009 & 7 & 7 & 17 & 31 & 11 & 16 & 9 & 7 & 14 & 11 & 17 & 12 \\
\hline Canada & 2010 & 6 & 9 & 11 & 36 & 12 & 11 & 8 & 6 & 14 & 16 & 16 & 11 \\
\hline Canada & 2011 & 6 & 11 & 11 & 49 & 13 & 12 & 12 & 5 & 14 & 16 & 24 & 11 \\
\hline Canada & 2012 & 7 & 13 & 11 & 51 & 11 & 13 & 15 & 4 & 13 & 20 & 26 & 22 \\
\hline Canada & 2014 & 7 & 15 & 14 & 51 & 8 & 15 & 18 & 7 & 13 & 22 & 23 & 22 \\
\hline Canada & 2015 & 7 & 14 & 16 & 39 & 4 & 15 & 19 & 7 & 14 & 18 & 22 & 24 \\
\hline Canada & 2016 & 9 & 15 & 18 & 41 & 7 & 17 & 19 & 8 & 15 & 21 & 24 & 24 \\
\hline Canada & 2017 & 8 & 16 & 15 & 47 & 7 & 18 & 13 & 7 & 16 & 23 & 23 & 23 \\
\hline France & 2008 & 9 & 2 & 23 & 65 & 25 & 21 & 16 & 105 & 7 & 20 & 9 & 16 \\
\hline France & 2009 & 11 & 3 & 26 & 58 & 21 & 25 & 15 & 67 & 8 & 24 & 10 & 18 \\
\hline France & 2010 & 16 & 4 & 26 & 44 & 16 & 32 & 17 & 60 & 7 & 12 & 12 & 19 \\
\hline France & 2011 & 16 & 4 & 28 & 83 & 18 & 38 & 20 & 68 & 7 & 13 & 14 & 17 \\
\hline France & 2012 & 21 & 4 & 32 & 68 & 27 & 46 & 27 & 66 & 8 & 14 & 21 & 17 \\
\hline France & 2013 & 24 & 4 & 31 & 73 & 33 & 45 & 24 & 71 & 8 & 17 & 21 & 19 \\
\hline France & 2014 & 18 & 8 & 32 & 82 & 23 & 46 & 28 & 61 & 8 & 18 & 22 & 19 \\
\hline France & 2015 & 16 & 8 & 29 & 77 & 29 & 35 & 25 & 51 & 8 & 16 & 20 & 18 \\
\hline France & 2016 & 19 & 7 & 29 & 67 & 31 & 31 & 21 & 51 & 7 & 17 & 14 & 17 \\
\hline France & 2017 & 24 & 7 & 31 & 63 & 33 & 36 & 22 & 56 & 8 & 21 & 16 & 17 \\
\hline Germany & 2008 & 24 & 1 & 14 & 40 & 19 & 15 & 21 & 58 & 4 & 18 & 1 & 8 \\
\hline Germany & 2012 & 22 & 3 & 16 & 30 & 32 & 21 & 5 & 53 & 5 & 15 & 3 & 7 \\
\hline Germany & 2013 & 21 & 3 & 15 & 27 & 29 & 21 & 3 & 41 & 5 & 14 & 3 & 4 \\
\hline Germany & 2014 & 14 & 7 & 17 & 24 & 25 & 19 & 16 & 35 & 5 & 13 & 3 & 6 \\
\hline Germany & 2015 & 13 & 7 & 20 & 20 & 18 & 23 & 17 & 28 & 5 & 12 & 3 & 6 \\
\hline Germany & 2016 & 14 & 8 & 22 & 15 & 20 & 23 & 16 & 22 & 5 & 10 & 3 & 5 \\
\hline Germany & 2017 & 13 & 10 & 21 & 12 & 12 & 11 & 15 & 14 & 5 & 8 & 5 & 5 \\
\hline Italy & 2008 & 30 & 54 & 84 & 100 & 91 & 62 & 44 & 126 & 9 & 31 & 21 & 53 \\
\hline Italy & 2009 & 27 & 59 & 97 & 102 & 100 & 65 & 49 & 117 & 9 & 39 & 20 & 50 \\
\hline Italy & 2010 & 26 & 31 & 92 & 76 & 101 & 68 & 47 & 118 & 9 & 43 & 23 & 50 \\
\hline Italy & 2011 & 20 & 32 & 88 & 92 & 97 & 59 & 41 & 123 & 9 & 42 & 26 & 43 \\
\hline Italy & 2012 & 25 & 28 & 97 & 102 & 111 & 65 & 45 & 127 & 10 & 40 & 28 & 36 \\
\hline Italy & 2013 & 26 & 25 & 102 & 101 & 124 & 87 & 42 & 137 & 10 & 37 & 27 & 38 \\
\hline Italy & 2014 & 22 & 26 & 106 & 108 & 119 & 73 & 47 & 136 & 12 & 38 & 25 & 35 \\
\hline Italy & 2015 & 26 & 26 & 106 & 111 & 117 & 71 & 45 & 126 & 12 & 37 & 24 & 32 \\
\hline Italy & 2016 & 23 & 25 & 103 & 98 & 127 & 67 & 43 & 119 & 12 & 40 & 25 & 32 \\
\hline Italy & 2017 & 25 & 27 & 95 & 96 & 126 & 60 & 41 & 116 & 12 & 41 & 25 & 34 \\
\hline Japan & 2008 & 22 & 11 & 26 & 98 & 42 & 18 & 23 & 11 & 3 & 21 & 3 & 4 \\
\hline Japan & 2009 & 19 & 13 & 28 & 97 & 61 & 41 & 69 & 75 & 16 & 88 & 1 & 4 \\
\hline Japan & 2010 & 9 & 11 & 25 & 105 & 39 & 17 & 20 & 13 & 3 & 28 & 1 & 4 \\
\hline Japan & 2011 & 9 & 15 & 24 & 113 & 32 & 18 & 19 & 12 & 4 & 25 & 1 & 4 \\
\hline Japan & 2012 & 10 & 11 & 22 & 124 & 36 & 20 & 21 & 20 & 4 & 16 & 1 & 5 \\
\hline Japan & 2013 & 10 & 9 & 17 & 127 & 23 & 16 & 21 & 23 & 4 & 19 & 1 & 5 \\
\hline Japan & 2014 & 6 & 6 & 11 & 127 & 16 & 12 & 21 & 22 & 4 & 20 & 1 & 4 \\
\hline
\end{tabular}




\begin{tabular}{|c|c|c|c|c|c|c|c|c|c|c|c|c|c|}
\hline Japan & 2015 & 4 & 5 & 13 & 121 & 19 & 11 & 21 & 21 & 4 & 19 & 2 & 5 \\
\hline Japan & 2016 & 5 & 5 & 16 & 104 & 17 & 16 & 23 & 19 & 4 & 19 & 2 & 8 \\
\hline Japan & 2017 & 7 & 4 & 17 & 93 & 20 & 13 & 23 & 22 & 4 & 15 & 3 & 8 \\
\hline Russian Federation & 2008 & 59 & 59 & 110 & 29 & 112 & 99 & 46 & 27 & 8 & 67 & 91 & 48 \\
\hline Russian Federation & 2009 & 51 & 71 & 114 & 36 & 119 & 108 & 51 & 43 & 7 & 74 & 95 & 51 \\
\hline Russian Federation & 2010 & 53 & 47 & 118 & 79 & 125 & 123 & 50 & 57 & 8 & 69 & 101 & 57 \\
\hline Russian Federation & 2011 & 68 & 48 & 128 & 44 & 127 & 128 & 52 & 65 & 8 & 68 & 114 & 71 \\
\hline Russian Federation & 2012 & 65 & 47 & 133 & 22 & 130 & 134 & 52 & 84 & 7 & 57 & 119 & 85 \\
\hline Russian Federation & 2014 & 56 & 39 & 97 & 31 & 110 & 99 & 39 & 45 & 7 & 59 & 86 & 65 \\
\hline Russian Federation & 2015 & 56 & 35 & 100 & 40 & 95 & 92 & 38 & 50 & 6 & 60 & 80 & 68 \\
\hline Russian Federation & 2016 & 62 & 35 & 88 & 91 & 108 & 87 & 32 & 49 & 6 & 62 & 72 & 56 \\
\hline Russian Federation & 2017 & 54 & 35 & 83 & 53 & 107 & 80 & 32 & 60 & 6 & 57 & 71 & 49 \\
\hline United Kingdom & 2008 & 19 & 18 & 25 & 58 & 5 & 19 & 18 & 8 & 6 & 8 & 17 & 17 \\
\hline United Kingdom & 2009 & 23 & 20 & 21 & 71 & 24 & 20 & 18 & 8 & 6 & 8 & 12 & 15 \\
\hline United Kingdom & 2010 & 19 & 8 & 17 & 56 & 25 & 22 & 18 & 8 & 6 & 8 & 9 & 14 \\
\hline United Kingdom & 2011 & 14 & 6 & 15 & 85 & 20 & 19 & 16 & 7 & 6 & 8 & 8 & 13 \\
\hline United Kingdom & 2013 & 16 & 8 & 12 & 115 & 15 & 14 & 17 & 5 & 6 & 4 & 9 & 12 \\
\hline United Kingdom & 2014 & 21 & 10 & 12 & 107 & 15 & 13 & 19 & 5 & 6 & 2 & 6 & 12 \\
\hline United Kingdom & 2015 & 18 & 9 & 14 & 108 & 16 & 12 & 18 & 5 & 9 & 3 & 6 & 12 \\
\hline United Kingdom & 2016 & 17 & 9 & 14 & 85 & 16 & 9 & 20 & 5 & 9 & 3 & 7 & 13 \\
\hline United Kingdom & 2017 & 17 & 11 & 12 & 68 & 13 & 10 & 20 & 6 & 7 & 4 & 7 & 12 \\
\hline United States & 2008 & 34 & 7 & 29 & 66 & 9 & 8 & 5 & 1 & 1 & 11 & 4 & 1 \\
\hline United States & 2009 & 36 & 8 & 34 & 93 & 20 & 12 & 7 & 3 & 1 & 13 & 5 & 1 \\
\hline United States & 2010 & 42 & 15 & 40 & 87 & 31 & 26 & 9 & 4 & 1 & 17 & 8 & 1 \\
\hline United States & 2011 & 42 & 16 & 39 & 90 & 22 & 24 & 13 & 4 & 1 & 20 & 10 & 5 \\
\hline United States & 2012 & 34 & 14 & 41 & 111 & 16 & 23 & 8 & 6 & 1 & 11 & 10 & 6 \\
\hline United States & 2013 & 34 & 15 & 35 & 117 & 10 & 20 & 7 & 4 & 1 & 15 & 6 & 7 \\
\hline United States & 2014 & 49 & 12 & 30 & 113 & 9 & 16 & 7 & 4 & 1 & 16 & 4 & 5 \\
\hline United States & 2015 & 46 & 11 & 28 & 96 & 5 & 16 & 6 & 4 & 2 & 17 & 4 & 4 \\
\hline United States & 2016 & 39 & 11 & 27 & 71 & 3 & 14 & 8 & 4 & 2 & 14 & 4 & 4 \\
\hline United States & 2017 & 29 & 9 & 20 & 83 & 2 & 7 & 3 & 3 & 2 & 6 & 2 & 2 \\
\hline
\end{tabular}

Table A2: Turkey compared with ASEAN-5 countries

\begin{tabular}{|c|c|c|c|c|c|c|c|c|c|c|c|c|c|}
\hline Country & Year & Brhpe & Brinf & Brins & Brmee & Eefmd & Eegme & Eehet & Eelme & Eemas & Eetrd & Isbus & Isinn \\
\hline Turkey & 2008 & 78 & 66 & 80 & 79 & 76 & 55 & 72 & 125 & 15 & 58 & 60 & 66 \\
\hline Turkey & 2009 & 74 & 62 & 96 & 64 & 80 & 56 & 73 & 120 & 15 & 54 & 52 & 69 \\
\hline Turkey & 2010 & 72 & 56 & 88 & 83 & 61 & 59 & 71 & 127 & 16 & 56 & 52 & 67 \\
\hline Turkey & 2011 & 75 & 51 & 80 & 69 & 55 & 47 & 74 & 133 & 17 & 55 & 58 & 69 \\
\hline Turkey & 2012 & 63 & 51 & 64 & 55 & 44 & 38 & 74 & 124 & 15 & 53 & 47 & 55 \\
\hline Turkey & 2013 & 59 & 49 & 56 & 76 & 51 & 43 & 65 & 130 & 16 & 58 & 43 & 50 \\
\hline Turkey & 2014 & 69 & 51 & 64 & 58 & 58 & 43 & 50 & 131 & 16 & 55 & 50 & 56 \\
\hline Turkey & 2015 & 73 & 53 & 75 & 68 & 64 & 45 & 55 & 127 & 16 & 64 & 58 & 60 \\
\hline Turkey & 2016 & 79 & 48 & 74 & 54 & 82 & 52 & 50 & 126 & 17 & 67 & 65 & 71 \\
\hline Turkey & 2017 & 84 & 53 & 71 & 50 & 80 & 53 & 48 & 127 & 14 & 62 & 67 & 69 \\
\hline Indonesia & 2008 & 87 & 86 & 68 & 72 & 57 & 37 & 71 & 43 & 17 & 88 & 39 & 47 \\
\hline Indonesia & 2009 & 82 & 84 & 58 & 52 & 61 & 41 & 69 & 75 & 16 & 88 & 40 & 39 \\
\hline Indonesia & 2010 & 62 & 82 & 61 & 35 & 62 & 49 & 66 & 84 & 15 & 91 & 37 & 36 \\
\hline Indonesia & 2011 & 64 & 76 & 71 & 23 & 69 & 67 & 69 & 94 & 15 & 94 & 45 & 36 \\
\hline Indonesia & 2012 & 70 & 78 & 72 & 25 & 70 & 63 & 73 & 120 & 16 & 85 & 42 & 39 \\
\hline Indonesia & 2013 & 72 & 61 & 67 & 26 & 60 & 50 & 64 & 103 & 15 & 75 & 37 & 33 \\
\hline Indonesia & 2014 & 74 & 56 & 53 & 34 & 42 & 48 & 61 & 110 & 15 & 77 & 34 & 31 \\
\hline Indonesia & 2015 & 80 & 62 & 55 & 33 & 49 & 55 & 65 & 115 & 10 & 85 & 36 & 30 \\
\hline Indonesia & 2016 & 100 & 60 & 56 & 30 & 42 & 58 & 63 & 108 & 10 & 91 & 39 & 31 \\
\hline Indonesia & 2017 & 94 & 52 & 47 & 26 & 37 & 43 & 64 & 96 & 9 & 80 & 32 & 31 \\
\hline Malaysia & 2008 & 23 & 23 & 30 & 38 & 16 & 23 & 35 & 18 & 28 & 34 & 22 & 22 \\
\hline Malaysia & 2009 & 34 & 26 & 43 & 42 & 6 & 30 & 41 & 31 & 28 & 37 & 24 & 24 \\
\hline Malaysia & 2010 & 34 & 30 & 42 & 41 & 7 & 27 & 49 & 35 & 29 & 40 & 25 & 24 \\
\hline Malaysia & 2011 & 33 & 26 & 30 & 29 & 3 & 15 & 38 & 20 & 29 & 44 & 20 & 24 \\
\hline Malaysia & 2012 & 33 & 32 & 29 & 35 & 6 & 11 & 39 & 24 & 28 & 51 & 20 & 25 \\
\hline Malaysia & 2013 & 33 & 29 & 29 & 38 & 6 & 10 & 46 & 25 & 26 & 51 & 20 & 25 \\
\hline Malaysia & 2014 & 33 & 25 & 20 & 44 & 4 & 7 & 46 & 19 & 26 & 60 & 15 & 21 \\
\hline Malaysia & 2015 & 24 & 24 & 23 & 35 & 9 & 6 & 36 & 19 & 26 & 47 & 13 & 20 \\
\hline
\end{tabular}




\begin{tabular}{|c|c|c|c|c|c|c|c|c|c|c|c|c|c|}
\hline Malaysia & 2016 & 44 & 24 & 26 & 35 & 13 & 12 & 41 & 24 & 24 & 43 & 20 & 22 \\
\hline Malaysia & 2017 & 30 & 22 & 27 & 34 & 16 & 20 & 45 & 26 & 24 & 46 & 20 & 22 \\
\hline Philippines & 2008 & 90 & 92 & 105 & 53 & 78 & 81 & 60 & 101 & 34 & 70 & 57 & 76 \\
\hline Philippines & 2009 & 93 & 98 & 113 & 76 & 93 & 95 & 68 & 113 & 35 & 84 & 65 & 99 \\
\hline Philippines & 2010 & 90 & 104 & 125 & 68 & 75 & 97 & 73 & 111 & 37 & 95 & 60 & 111 \\
\hline Philippines & 2011 & 92 & 105 & 117 & 54 & 71 & 88 & 71 & 113 & 36 & 83 & 57 & 108 \\
\hline Philippines & 2012 & 98 & 98 & 94 & 36 & 58 & 86 & 64 & 103 & 35 & 79 & 49 & 94 \\
\hline Philippines & 2013 & 96 & 96 & 79 & 40 & 48 & 82 & 67 & 100 & 33 & 77 & 49 & 69 \\
\hline Philippines & 2014 & 92 & 91 & 67 & 26 & 49 & 70 & 64 & 91 & 35 & 69 & 46 & 52 \\
\hline Philippines & 2015 & 86 & 90 & 77 & 24 & 48 & 80 & 63 & 82 & 30 & 68 & 42 & 48 \\
\hline Philippines & 2016 & 81 & 95 & 91 & 20 & 48 & 99 & 58 & 86 & 31 & 83 & 52 & 62 \\
\hline Philippines & 2017 & 82 & 97 & 94 & 22 & 52 & 103 & 55 & 84 & 27 & 83 & 58 & 65 \\
\hline Singapore & 2008 & 16 & 4 & 1 & 21 & 2 & 1 & 8 & 2 & 41 & 7 & 14 & 11 \\
\hline Singapore & 2009 & 13 & 4 & 1 & 35 & 2 & 1 & 5 & 1 & 39 & 6 & 14 & 8 \\
\hline Singapore & 2010 & 3 & 5 & 1 & 33 & 2 & 1 & 5 & 1 & 41 & 11 & 15 & 19 \\
\hline Singapore & 2011 & 3 & 3 & 1 & 9 & 1 & 1 & 4 & 2 & 37 & 10 & 15 & 8 \\
\hline Singapore & 2012 & 3 & 2 & 1 & 17 & 2 & 1 & 2 & 2 & 37 & 5 & 14 & 8 \\
\hline Singapore & 2013 & 2 & 2 & 3 & 18 & 2 & 1 & 2 & 1 & 34 & 7 & 17 & 9 \\
\hline Singapore & 2014 & 3 & 2 & 3 & 15 & 2 & 1 & 2 & 2 & 31 & 7 & 19 & 9 \\
\hline Singapore & 2015 & 2 & 2 & 2 & 12 & 2 & 1 & 1 & 2 & 35 & 5 & 18 & 9 \\
\hline Singapore & 2016 & 2 & 2 & 2 & 11 & 2 & 1 & 1 & 2 & 37 & 9 & 19 & 9 \\
\hline Singapore & 2017 & 3 & 2 & 2 & 18 & 3 & 1 & 1 & 2 & 35 & 14 & 18 & 9 \\
\hline Thailand & 2008 & 58 & 29 & 57 & 41 & 49 & 46 & 51 & 13 & 21 & 66 & 46 & 54 \\
\hline Thailand & 2009 & 61 & 40 & 60 & 22 & 49 & 44 & 54 & 25 & 21 & 63 & 43 & 57 \\
\hline Thailand & 2010 & 80 & 35 & 64 & 46 & 51 & 41 & 59 & 24 & 23 & 68 & 48 & 52 \\
\hline Thailand & 2011 & 83 & 42 & 67 & 28 & 50 & 42 & 62 & 30 & 22 & 84 & 47 & 54 \\
\hline Thailand & 2012 & 78 & 46 & 77 & 27 & 43 & 37 & 60 & 76 & 22 & 84 & 46 & 68 \\
\hline Thailand & 2013 & 81 & 47 & 78 & 31 & 32 & 34 & 66 & 62 & 22 & 78 & 40 & 66 \\
\hline Thailand & 2014 & 66 & 48 & 84 & 19 & 34 & 30 & 59 & 66 & 22 & 65 & 41 & 67 \\
\hline Thailand & 2015 & 67 & 44 & 82 & 27 & 39 & 30 & 56 & 67 & 18 & 58 & 35 & 57 \\
\hline Thailand & 2016 & 86 & 49 & 84 & 13 & 39 & 37 & 62 & 71 & 18 & 63 & 43 & 54 \\
\hline Thailand & 2017 & 90 & 43 & 78 & 9 & 40 & 33 & 57 & 65 & 18 & 61 & 42 & 50 \\
\hline
\end{tabular}

Table A3: Turkey compared with G19 countries

\begin{tabular}{|c|c|c|c|c|c|c|c|c|c|c|c|c|c|}
\hline Country & Year & Brhpe & Brinf & Brins & Brmee & Eefmd & Eegme & Eehet & Eelme & Eemas & Eetrd & Isbus & Isinn \\
\hline Turkey & 2008 & 78 & 66 & 80 & 79 & 76 & 55 & 72 & 125 & 15 & 58 & 60 & 66 \\
\hline Turkey & 2009 & 74 & 62 & 96 & 64 & 80 & 56 & 73 & 120 & 15 & 54 & 52 & 69 \\
\hline Turkey & 2010 & 72 & 56 & 88 & 83 & 61 & 59 & 71 & 127 & 16 & 56 & 52 & 67 \\
\hline Turkey & 2011 & 75 & 51 & 80 & 69 & 55 & 47 & 74 & 133 & 17 & 55 & 58 & 69 \\
\hline Turkey & 2012 & 63 & 51 & 64 & 55 & 44 & 38 & 74 & 124 & 15 & 53 & 47 & 55 \\
\hline Turkey & 2013 & 59 & 49 & 56 & 76 & 51 & 43 & 65 & 130 & 16 & 58 & 43 & 50 \\
\hline Turkey & 2015 & 73 & 53 & 75 & 68 & 64 & 45 & 55 & 127 & 16 & 64 & 58 & 60 \\
\hline Turkey & 2016 & 79 & 48 & 74 & 54 & 82 & 52 & 50 & 126 & 17 & 67 & 65 & 71 \\
\hline Turkey & 2017 & 84 & 53 & 71 & 50 & 80 & 53 & 48 & 127 & 14 & 62 & 67 & 69 \\
\hline Canada & 2008 & 6 & 6 & 15 & 43 & 10 & 16 & 9 & 7 & 14 & 9 & 18 & 13 \\
\hline Canada & 2009 & 7 & 7 & 17 & 31 & 11 & 16 & 9 & 7 & 14 & 11 & 17 & 12 \\
\hline Canada & 2010 & 6 & 9 & 11 & 36 & 12 & 11 & 8 & 6 & 14 & 16 & 16 & 11 \\
\hline Canada & 2011 & 6 & 11 & 11 & 49 & 13 & 12 & 12 & 5 & 14 & 16 & 24 & 11 \\
\hline Canada & 2012 & 7 & 13 & 11 & 51 & 11 & 13 & 15 & 4 & 13 & 20 & 26 & 22 \\
\hline Canada & 2014 & 7 & 15 & 14 & 51 & 8 & 15 & 18 & 7 & 13 & 22 & 23 & 22 \\
\hline Canada & 2015 & 7 & 14 & 16 & 39 & 4 & 15 & 19 & 7 & 14 & 18 & 22 & 24 \\
\hline Canada & 2016 & 9 & 15 & 18 & 41 & 7 & 17 & 19 & 8 & 15 & 21 & 24 & 24 \\
\hline Canada & 2017 & 8 & 16 & 15 & 47 & 7 & 18 & 13 & 7 & 16 & 23 & 23 & 23 \\
\hline France & 2008 & 9 & 2 & 23 & 65 & 25 & 21 & 16 & 105 & 7 & 20 & 9 & 16 \\
\hline France & 2009 & 11 & 3 & 26 & 58 & 21 & 25 & 15 & 67 & 8 & 24 & 10 & 18 \\
\hline France & 2010 & 16 & 4 & 26 & 44 & 16 & 32 & 17 & 60 & 7 & 12 & 12 & 19 \\
\hline France & 2011 & 16 & 4 & 28 & 83 & 18 & 38 & 20 & 68 & 7 & 13 & 14 & 17 \\
\hline France & 2012 & 21 & 4 & 32 & 68 & 27 & 46 & 27 & 66 & 8 & 14 & 21 & 17 \\
\hline France & 2013 & 24 & 4 & 31 & 73 & 33 & 45 & 24 & 71 & 8 & 17 & 21 & 19 \\
\hline France & 2014 & 18 & 8 & 32 & 82 & 23 & 46 & 28 & 61 & 8 & 18 & 22 & 19 \\
\hline France & 2015 & 16 & 8 & 29 & 77 & 29 & 35 & 25 & 51 & 8 & 16 & 20 & 18 \\
\hline France & 2016 & 19 & 7 & 29 & 67 & 31 & 31 & 21 & 51 & 7 & 17 & 14 & 17 \\
\hline
\end{tabular}




\begin{tabular}{|c|c|c|c|c|c|c|c|c|c|c|c|c|c|}
\hline France & 2017 & 24 & 7 & 31 & 63 & 33 & 36 & 22 & 56 & 8 & 21 & 16 & 17 \\
\hline Germany & 2008 & 24 & 1 & 14 & 40 & 19 & 15 & 21 & 58 & 4 & 18 & 1 & 8 \\
\hline Germany & 2009 & 24 & 1 & 16 & 30 & 36 & 18 & 22 & 70 & 5 & 12 & 2 & 7 \\
\hline Germany & 2010 & 25 & 2 & 13 & 23 & 36 & 21 & 19 & 70 & 5 & 10 & 3 & 8 \\
\hline Germany & 2011 & 23 & 2 & 19 & 30 & 39 & 26 & 7 & 64 & 5 & 14 & 4 & 7 \\
\hline Germany & 2012 & 22 & 3 & 16 & 30 & 32 & 21 & 5 & 53 & 5 & 15 & 3 & 7 \\
\hline Germany & 2013 & 21 & 3 & 15 & 27 & 29 & 21 & 3 & 41 & 5 & 14 & 3 & 4 \\
\hline Germany & 2014 & 14 & 7 & 17 & 24 & 25 & 19 & 16 & 35 & 5 & 13 & 3 & 6 \\
\hline Germany & 2015 & 13 & 7 & 20 & 20 & 18 & 23 & 17 & 28 & 5 & 12 & 3 & 6 \\
\hline Germany & 2016 & 14 & 8 & 22 & 15 & 20 & 23 & 16 & 22 & 5 & 10 & 3 & 5 \\
\hline Germany & 2017 & 13 & 10 & 21 & 12 & 12 & 11 & 15 & 14 & 5 & 8 & 5 & 5 \\
\hline Italy & 2008 & 30 & 54 & 84 & 100 & 91 & 62 & 44 & 126 & 9 & 31 & 21 & 53 \\
\hline Italy & 2009 & 27 & 59 & 97 & 102 & 100 & 65 & 49 & 117 & 9 & 39 & 20 & 50 \\
\hline Italy & 2010 & 26 & 31 & 92 & 76 & 101 & 68 & 47 & 118 & 9 & 43 & 23 & 50 \\
\hline Italy & 2011 & 20 & 32 & 88 & 92 & 97 & 59 & 41 & 123 & 9 & 42 & 26 & 43 \\
\hline Italy & 2012 & 25 & 28 & 97 & 102 & 111 & 65 & 45 & 127 & 10 & 40 & 28 & 36 \\
\hline Italy & 2013 & 26 & 25 & 102 & 101 & 124 & 87 & 42 & 137 & 10 & 37 & 27 & 38 \\
\hline Italy & 2014 & 22 & 26 & 106 & 108 & 119 & 73 & 47 & 136 & 12 & 38 & 25 & 35 \\
\hline Italy & 2015 & 26 & 26 & 106 & 111 & 117 & 71 & 45 & 126 & 12 & 37 & 24 & 32 \\
\hline Italy & 2016 & 23 & 25 & 103 & 98 & 127 & 67 & 43 & 119 & 12 & 40 & 25 & 32 \\
\hline Italy & 2017 & 25 & 27 & 95 & 96 & 126 & 60 & 41 & 116 & 12 & 41 & 25 & 34 \\
\hline Japan & 2008 & 22 & 11 & 26 & 98 & 42 & 18 & 23 & 11 & 3 & 21 & 3 & 1 \\
\hline Japan & 2009 & 19 & 13 & 28 & 97 & 61 & 41 & 69 & 75 & 16 & 88 & 1 & \\
\hline Japan & 2010 & 9 & 11 & 25 & 105 & 39 & 17 & 20 & 13 & 3 & 28 & 1 & \\
\hline Japan & 2011 & 9 & 15 & 24 & 113 & 32 & 18 & 19 & 12 & 4 & 25 & 1 & 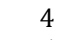 \\
\hline Japan & 2012 & 10 & 11 & 22 & 124 & 36 & 20 & 21 & 20 & 4 & 16 & 1 & \\
\hline Japan & 2013 & 10 & 9 & 17 & 127 & 23 & 16 & 21 & 23 & 4 & 19 & 1 & 5 \\
\hline Japan & 2014 & 6 & 6 & 11 & 127 & 16 & 12 & 21 & 22 & 4 & 20 & 1 & 4 \\
\hline Japan & 2015 & 4 & 5 & 13 & 121 & 19 & 11 & 21 & 21 & 4 & 19 & 2 & 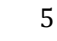 \\
\hline Japan & 2016 & 5 & 5 & 16 & 104 & 17 & 16 & 23 & 19 & 4 & 19 & 2 & 0 \\
\hline Japan & 2017 & 7 & 4 & 17 & 93 & 20 & 13 & 23 & 22 & 4 & 15 & 3 & 0 \\
\hline Russian Federation & 2008 & 59 & 59 & 110 & 29 & 112 & 99 & 46 & 27 & 8 & 67 & 91 & 48 \\
\hline Russian Federation & 2009 & 51 & 71 & 114 & 36 & 119 & 108 & 51 & 43 & 7 & 74 & 95 & 51 \\
\hline Russian Federation & 2010 & 53 & 47 & 118 & 79 & 125 & 123 & 50 & 57 & 8 & 69 & 101 & 57 \\
\hline Russian Federation & 2011 & 68 & 48 & 128 & 44 & 127 & 128 & 52 & 65 & 8 & 68 & 114 & 71 \\
\hline Russian Federation & 2012 & 65 & 47 & 133 & 22 & 130 & 134 & 52 & 84 & 7 & 57 & 119 & 85 \\
\hline Russian Federation & 2013 & 71 & 45 & 121 & 19 & 121 & 126 & 47 & 72 & 7 & 59 & 107 & 78 \\
\hline Russian Federation & 2014 & 56 & 39 & 97 & 31 & 110 & 99 & 39 & 45 & 7 & 59 & 86 & 65 \\
\hline Russian Federation & 2015 & 56 & 35 & 100 & 40 & 95 & 92 & 38 & 50 & 6 & 60 & 80 & 68 \\
\hline Russian Federation & 2016 & 62 & 35 & 88 & 91 & 108 & 87 & 32 & 49 & 6 & 62 & 72 & 56 \\
\hline Russian Federation & 2017 & 54 & 35 & 83 & 53 & 107 & 80 & 32 & 60 & 6 & 57 & 71 & 49 \\
\hline United Kingdom & 2008 & 19 & 18 & 25 & 58 & 5 & 19 & 18 & 8 & 6 & 8 & 17 & 17 \\
\hline United Kingdom & 2009 & 23 & 20 & 21 & 71 & 24 & 20 & 18 & 8 & 6 & 8 & 12 & 15 \\
\hline United Kingdom & 2010 & 19 & 8 & 17 & 56 & 25 & 22 & 18 & 8 & 6 & 8 & 9 & \\
\hline United Kingdom & 2011 & 14 & 6 & 15 & 85 & 20 & 19 & 16 & 7 & 6 & 8 & 8 & 13 \\
\hline United Kingdom & 2012 & 17 & 6 & 13 & 110 & 13 & 17 & 16 & 5 & 6 & 7 & 8 & 10 \\
\hline United Kingdom & 2013 & 16 & 8 & 12 & 115 & 15 & 14 & 17 & 5 & 6 & 4 & 9 & 12 \\
\hline United Kingdom & 2014 & 21 & 10 & 12 & 107 & 15 & 13 & 19 & 5 & 6 & 2 & 6 & 12 \\
\hline United Kingdom & 2015 & 18 & 9 & 14 & 108 & 16 & 12 & 18 & 5 & 9 & 3 & 6 & 12 \\
\hline United Kingdom & 2016 & 17 & 9 & 14 & 85 & 16 & 9 & 20 & 5 & 9 & 3 & 7 & 13 \\
\hline United Kingdom & 2017 & 17 & 11 & 12 & 68 & 13 & 10 & 20 & 6 & 7 & 4 & 7 & 12 \\
\hline United States & 2008 & 34 & 7 & 29 & 66 & 9 & 8 & 5 & 1 & 1 & 11 & 4 & \\
\hline United States & 2009 & 36 & 8 & 34 & 93 & 20 & 12 & 7 & 3 & 1 & 13 & 5 & \\
\hline United States & 2010 & 42 & 15 & 40 & 87 & 31 & 26 & 9 & 4 & 1 & 17 & 8 & \\
\hline United States & 2011 & 42 & 16 & 39 & 90 & 22 & 24 & 13 & 4 & 1 & 20 & 10 & - \\
\hline United States & 2012 & 34 & 14 & 41 & 111 & 16 & 23 & 8 & 6 & 1 & 11 & 10 & 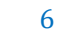 \\
\hline United States & 2013 & 34 & 15 & 35 & 117 & 10 & 20 & 7 & 4 & 1 & 15 & 6 & 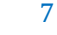 \\
\hline United States & 2014 & 49 & 12 & 30 & 113 & 9 & 16 & 7 & 4 & 1 & 16 & 4 & 3 \\
\hline United States & 2015 & 46 & 11 & 28 & 96 & 5 & 16 & 6 & 4 & 2 & 17 & 4 & \\
\hline United States & 2016 & 39 & 11 & 27 & 71 & 3 & 14 & 8 & 4 & 2 & 14 & 4 & \\
\hline United States & 2017 & 29 & 9 & 20 & 83 & 2 & 7 & 3 & 3 & 2 & 6 & 2 & 2 \\
\hline Argentina & 2008 & 61 & 87 & 128 & 64 & 117 & 122 & 56 & 130 & 24 & 76 & 71 & 98 \\
\hline Argentina & 2009 & 59 & 88 & 126 & 48 & 116 & 124 & 55 & 123 & 23 & 68 & 73 & 86 \\
\hline Argentina & 2010 & 60 & 77 & 132 & 54 & 126 & 135 & 55 & 128 & 24 & 73 & 75 & 73 \\
\hline Argentina & 2011 & 56 & 81 & 134 & 62 & 126 & 137 & 54 & 131 & 24 & 64 & 79 & 78 \\
\hline Argentina & 2012 & 59 & 86 & 138 & 94 & 131 & 140 & 53 & 140 & 23 & 67 & 89 & 91 \\
\hline Argentina & 2013 & 61 & 89 & 143 & 111 & 133 & 145 & 49 & 144 & 24 & 88 & 95 & 104 \\
\hline Argentina & 2014 & 67 & 89 & 137 & 102 & 129 & 141 & 45 & 143 & 24 & 82 & 96 & 97 \\
\hline Argentina & 2015 & 68 & 87 & 135 & 114 & 132 & 138 & 39 & 139 & 27 & 69 & 101 & 93 \\
\hline
\end{tabular}




\begin{tabular}{|c|c|c|c|c|c|c|c|c|c|c|c|c|c|}
\hline Argentina & 2016 & 63 & 85 & 130 & 130 & 127 & 135 & 40 & 130 & 28 & 69 & 88 & 81 \\
\hline Argentina & 2017 & 64 & 81 & 113 & 125 & 121 & 133 & 38 & 132 & 32 & 66 & 78 & 72 \\
\hline Australia & 2008 & 15 & 21 & 12 & 28 & 6 & 10 & 14 & 9 & 19 & 19 & 26 & 20 \\
\hline Australia & 2009 & 16 & 25 & 12 & 18 & 4 & 9 & 14 & 9 & 19 & 20 & 26 & 20 \\
\hline Australia & 2010 & 13 & 22 & 14 & 17 & 3 & 18 & 14 & 11 & 18 & 23 & 29 & 21 \\
\hline Australia & 2011 & 10 & 24 & 13 & 26 & 6 & 22 & 11 & 13 & 19 & 22 & 29 & 22 \\
\hline Australia & 2012 & 13 & 18 & 18 & 26 & 8 & 24 & 11 & 42 & 21 & 19 & 30 & 23 \\
\hline Australia & 2013 & 22 & 18 & 23 & 25 & 7 & 31 & 15 & 54 & 18 & 12 & 30 & 22 \\
\hline Australia & 2014 & 17 & 20 & 19 & 30 & 6 & 29 & 11 & 56 & 18 & 19 & 28 & 25 \\
\hline Australia & 2015 & 9 & 16 & 19 & 28 & 7 & 27 & 8 & 36 & 22 & 21 & 27 & 23 \\
\hline Australia & 2016 & 10 & 17 & 19 & 23 & 6 & 27 & 9 & 28 & 22 & 24 & 28 & 26 \\
\hline Australia & 2017 & 12 & 28 & 18 & 27 & 6 & 28 & 9 & 28 & 22 & 27 & 28 & 27 \\
\hline Brazil & 2008 & 79 & 78 & 91 & 122 & 64 & 101 & 58 & 91 & 10 & 56 & 35 & 43 \\
\hline Brazil & 2009 & 79 & 74 & 93 & 109 & 51 & 99 & 58 & 80 & 10 & 46 & 32 & 43 \\
\hline Brazil & 2010 & 87 & 62 & 93 & 111 & 50 & 114 & 58 & 96 & 10 & 54 & 31 & 42 \\
\hline Brazil & 2011 & 87 & 64 & 77 & 115 & 43 & 113 & 57 & 83 & 10 & 54 & 31 & 4 \\
\hline Brazil & 2012 & 88 & 70 & 79 & 62 & 46 & 104 & 66 & 69 & 9 & 48 & 33 & 49 \\
\hline Brazil & 2013 & 89 & 71 & 80 & 75 & 50 & 123 & 72 & 92 & 9 & 55 & 39 & 55 \\
\hline Brazil & 2014 & 77 & 76 & 94 & 85 & 53 & 123 & 41 & 109 & 9 & 58 & 47 & 62 \\
\hline Brazil & 2015 & 103 & 74 & 121 & 117 & 58 & 128 & 93 & 122 & 7 & 54 & 56 & 84 \\
\hline Brazil & 2016 & 99 & 72 & 120 & 126 & 93 & 128 & 84 & 117 & 8 & 59 & 63 & 100 \\
\hline Brazil & 2017 & 96 & 73 & 109 & 124 & 92 & 122 & 79 & 114 & 10 & 55 & 56 & 85 \\
\hline China & 2008 & 50 & 47 & 56 & 11 & 109 & 51 & 64 & 51 & 2 & 77 & 43 & 28 \\
\hline China & 2009 & 45 & 46 & 48 & 8 & 81 & 42 & 61 & 32 & 2 & 79 & 38 & 26 \\
\hline China & 2010 & 37 & 50 & 49 & 4 & 57 & 43 & 60 & 38 & 2 & 78 & 41 & 26 \\
\hline China & 2011 & 32 & 44 & 48 & 10 & 48 & 45 & 58 & 36 & 2 & 77 & 37 & \\
\hline China & 2012 & 35 & 48 & 50 & 11 & 54 & 59 & 62 & 41 & 2 & 88 & 45 & 33 \\
\hline China & 2013 & 40 & 48 & 47 & 10 & 54 & 61 & 70 & 34 & 2 & 85 & 45 & 32 \\
\hline China & 2014 & 46 & 46 & 47 & 10 & 54 & 56 & 65 & 37 & 2 & 83 & 43 & 32 \\
\hline China & 2015 & 44 & 39 & 51 & 8 & 54 & 58 & 68 & 37 & 1 & 74 & 38 & 31 \\
\hline China & 2016 & 41 & 42 & 45 & 8 & 56 & 56 & 54 & 39 & 1 & 74 & 34 & 30 \\
\hline China & 2017 & 40 & 46 & 41 & 17 & 48 & 46 & 47 & 38 & 1 & 73 & 33 & 28 \\
\hline India & 2008 & 100 & 72 & 53 & 109 & 34 & 47 & 63 & 89 & 5 & 69 & 27 & 32 \\
\hline India & 2009 & 101 & 76 & 54 & 96 & 16 & 48 & 66 & 83 & 4 & 83 & 27 & 30 \\
\hline India & 2010 & 104 & 86 & 58 & 73 & 17 & 71 & 85 & 92 & 4 & 86 & 44 & 39 \\
\hline India & 2011 & 101 & 89 & 69 & 105 & 21 & 70 & 87 & 81 & 3 & 93 & 43 & 38 \\
\hline India & 2012 & 101 & 84 & 70 & 99 & 21 & 75 & 86 & 82 & 3 & 96 & 40 & 41 \\
\hline India & 2013 & 102 & 85 & 72 & 110 & 19 & 85 & 91 & 99 & 3 & 98 & 42 & 41 \\
\hline India & 2014 & 98 & 87 & 70 & 101 & 51 & 95 & 93 & 112 & 3 & 121 & 57 & 49 \\
\hline India & 2015 & 84 & 81 & 60 & 91 & 53 & 91 & 90 & 103 & 3 & 120 & 52 & 42 \\
\hline India & 2016 & 85 & 68 & 42 & 75 & 38 & 60 & 81 & 84 & 3 & 110 & 35 & 29 \\
\hline India & 2017 & 91 & 66 & 39 & 80 & 42 & 56 & 75 & 75 & 3 & 107 & 39 & 29 \\
\hline Indonesia & 2008 & 87 & 86 & 68 & 72 & 57 & 37 & 71 & 43 & 17 & 88 & 39 & 47 \\
\hline Indonesia & 2009 & 82 & 84 & 58 & 52 & 61 & 41 & 69 & 75 & 16 & 88 & 40 & 39 \\
\hline Indonesia & 2010 & 62 & 82 & 61 & 35 & 62 & 49 & 66 & 84 & 15 & 91 & 37 & 36 \\
\hline Indonesia & 2011 & 64 & 76 & 71 & 23 & 69 & 67 & 69 & 94 & 15 & 94 & 45 & 36 \\
\hline Indonesia & 2012 & 70 & 78 & 72 & 25 & 70 & 63 & 73 & 120 & 16 & 85 & 42 & 39 \\
\hline Indonesia & 2013 & 72 & 61 & 67 & 26 & 60 & 50 & 64 & 103 & 15 & 75 & 37 & 33 \\
\hline Indonesia & 2014 & 74 & 56 & 53 & 34 & 42 & 48 & 61 & 110 & 15 & 77 & 34 & 31 \\
\hline Indonesia & 2015 & 80 & 62 & 55 & 33 & 49 & 55 & 65 & 115 & 10 & 85 & 36 & 30 \\
\hline Indonesia & 2016 & 100 & 60 & 56 & 30 & 42 & 58 & 63 & 108 & 10 & 91 & 39 & 31 \\
\hline Indonesia & 2017 & 94 & 52 & 47 & 26 & 37 & 43 & 64 & 96 & 9 & 80 & 32 & 31 \\
\hline Korea Rep. & 2008 & 26 & 15 & 28 & 4 & 37 & 22 & 12 & 41 & 13 & 13 & 16 & 9 \\
\hline Korea Rep. & 2009 & 27 & 17 & 53 & 11 & 58 & 36 & 16 & 84 & 12 & 15 & 21 & 11 \\
\hline Korea Rep. & 2010 & 21 & 18 & 62 & 6 & 83 & 38 & 15 & 78 & 11 & 19 & 24 & 12 \\
\hline Korea Rep. & 2011 & 15 & 9 & 65 & 6 & 80 & 37 & 17 & 76 & 11 & 18 & 25 & 14 \\
\hline Korea Rep. & 2012 & 11 & 9 & 62 & 10 & 71 & 29 & 17 & 73 & 11 & 18 & 22 & 16 \\
\hline Korea Rep. & 2013 & 18 & 11 & 74 & 9 & 81 & 33 & 19 & 78 & 12 & 22 & 24 & 17 \\
\hline Korea Rep. & 2014 & 27 & 14 & 82 & 7 & 80 & 33 & 23 & 86 & 11 & 25 & 27 & 17 \\
\hline Korea Rep. & 2015 & 23 & 13 & 69 & 5 & 87 & 26 & 23 & 83 & 13 & 27 & 26 & 19 \\
\hline Korea Rep. & 2016 & 29 & 10 & 63 & 3 & 80 & 24 & 25 & 77 & 13 & 28 & 23 & 20 \\
\hline Korea Rep. & 2017 & 28 & 8 & 58 & 2 & 74 & 24 & 25 & 73 & 13 & 29 & 26 & 18 \\
\hline Mexico & 2008 & 65 & 68 & 97 & 48 & 66 & 73 & 74 & 110 & 11 & 71 & 58 & 90 \\
\hline Mexico & 2009 & 65 & 69 & 98 & 28 & 73 & 90 & 74 & 115 & 11 & 71 & 62 & \\
\hline Mexico & 2010 & 70 & 75 & 106 & 28 & 96 & 96 & 79 & 120 & 12 & 71 & 67 & \\
\hline Mexico & 2011 & 69 & 66 & 103 & 39 & 83 & 84 & 72 & 114 & 12 & 63 & 56 & 63 \\
\hline Mexico & 2012 & 68 & 68 & 92 & 40 & 61 & 79 & 77 & 102 & 12 & 72 & 44 & \\
\hline Mexico & 2013 & 73 & 64 & 96 & 49 & 59 & 83 & 85 & 113 & 11 & 74 & 55 & 61 \\
\hline Mexico & 2014 & 71 & 65 & 102 & 53 & 63 & 86 & 87 & 121 & 10 & 79 & 58 & 61 \\
\hline
\end{tabular}




\begin{tabular}{|c|c|c|c|c|c|c|c|c|c|c|c|c|c|}
\hline Mexico & 2015 & 71 & 59 & 109 & 56 & 46 & 82 & 86 & 114 & 11 & 73 & 50 & 59 \\
\hline Mexico & 2016 & 74 & 57 & 116 & 51 & 35 & 70 & 82 & 105 & 11 & 73 & 45 & 55 \\
\hline Mexico & 2017 & 76 & 62 & 123 & 43 & 36 & 70 & 80 & 105 & 11 & 71 & 49 & 56 \\
\hline Saudi Arabia & 2008 & 51 & 41 & 34 & 9 & 73 & 34 & 53 & 63 & 22 & 51 & 41 & 34 \\
\hline Saudi Arabia & 2009 & 71 & 36 & 32 & 9 & 53 & 29 & 53 & 71 & 22 & 44 & 35 & 32 \\
\hline Saudi Arabia & 2010 & 74 & 28 & 21 & 22 & 22 & 10 & 51 & 66 & 22 & 42 & 19 & 28 \\
\hline Saudi Arabia & 2011 & 61 & 25 & 12 & 12 & 16 & 4 & 36 & 50 & 23 & 43 & 17 & 26 \\
\hline Saudi Arabia & 2012 & 58 & 26 & 15 & 6 & 22 & 14 & 40 & 59 & 24 & 35 & 25 & 29 \\
\hline Saudi Arabia & 2013 & 53 & 31 & 20 & 4 & 27 & 27 & 48 & 70 & 23 & 41 & 28 & 30 \\
\hline Saudi Arabia & 2014 & 50 & 30 & 25 & 4 & 30 & 35 & 57 & 64 & 20 & 45 & 30 & 33 \\
\hline Saudi Arabia & 2015 & 49 & 30 & 24 & 4 & 41 & 29 & 49 & 60 & 17 & 42 & 29 & 34 \\
\hline Saudi Arabia & 2016 & 51 & 31 & 24 & 68 & 47 & 41 & 46 & 65 & 14 & 41 & 31 & 42 \\
\hline Saudi Arabia & 2017 & 51 & 29 & 26 & 58 & 56 & 42 & 43 & 80 & 15 & 44 & 34 & 40 \\
\hline South Africa & 2008 & 122 & 48 & 46 & 63 & 24 & 31 & 57 & 88 & 23 & 49 & 33 & 37 \\
\hline South Africa & 2009 & 125 & 45 & 45 & 68 & 5 & 35 & 65 & 90 & 24 & 65 & 36 & 41 \\
\hline South Africa & 2010 & 129 & 63 & 47 & 43 & 9 & 40 & 75 & 97 & 25 & 76 & 38 & 44 \\
\hline South Africa & 2011 & 131 & 62 & 46 & 55 & 4 & 32 & 73 & 95 & 25 & 76 & 38 & 41 \\
\hline South Africa & 2012 & 132 & 63 & 43 & 69 & 3 & 32 & 84 & 113 & 25 & 62 & 38 & 42 \\
\hline South Africa & 2013 & 135 & 66 & 41 & 95 & 3 & 28 & 89 & 116 & 25 & 62 & 35 & 39 \\
\hline South Africa & 2014 & 132 & 60 & 36 & 89 & 7 & 32 & 86 & 113 & 25 & 66 & 31 & 43 \\
\hline South Africa & 2015 & 126 & 68 & 38 & 85 & 12 & 38 & 83 & 107 & 29 & 50 & 33 & 38 \\
\hline South Africa & 2016 & 123 & 64 & 40 & 79 & 11 & 28 & 77 & 97 & 30 & 49 & 30 & 35 \\
\hline South Africa & 2017 & 121 & 61 & 76 & 82 & 44 & 54 & 85 & 93 & 30 & 54 & 37 & 39 \\
\hline
\end{tabular}




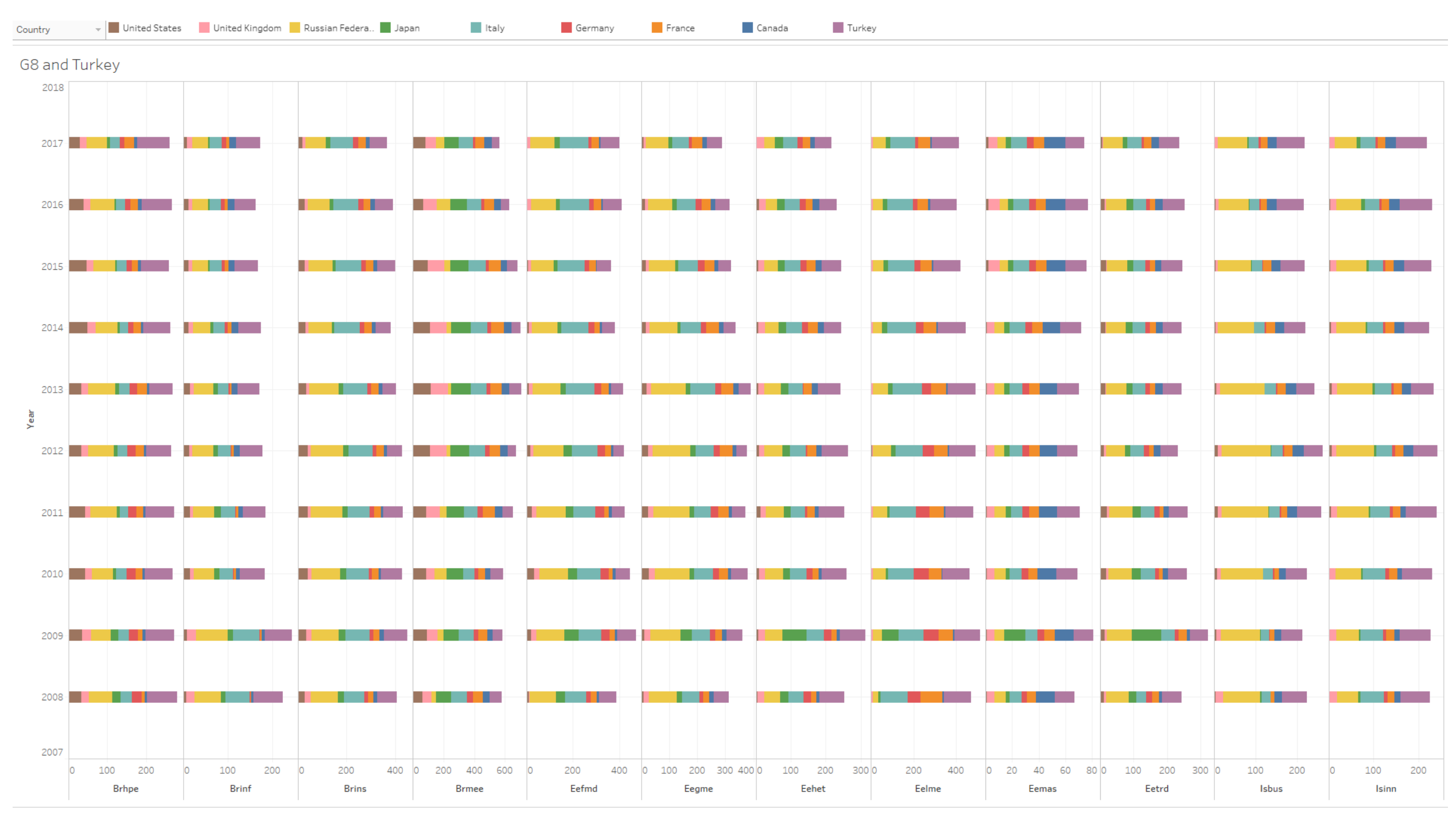

\section{Source: Author}

Figure A1: Turkey and G8 


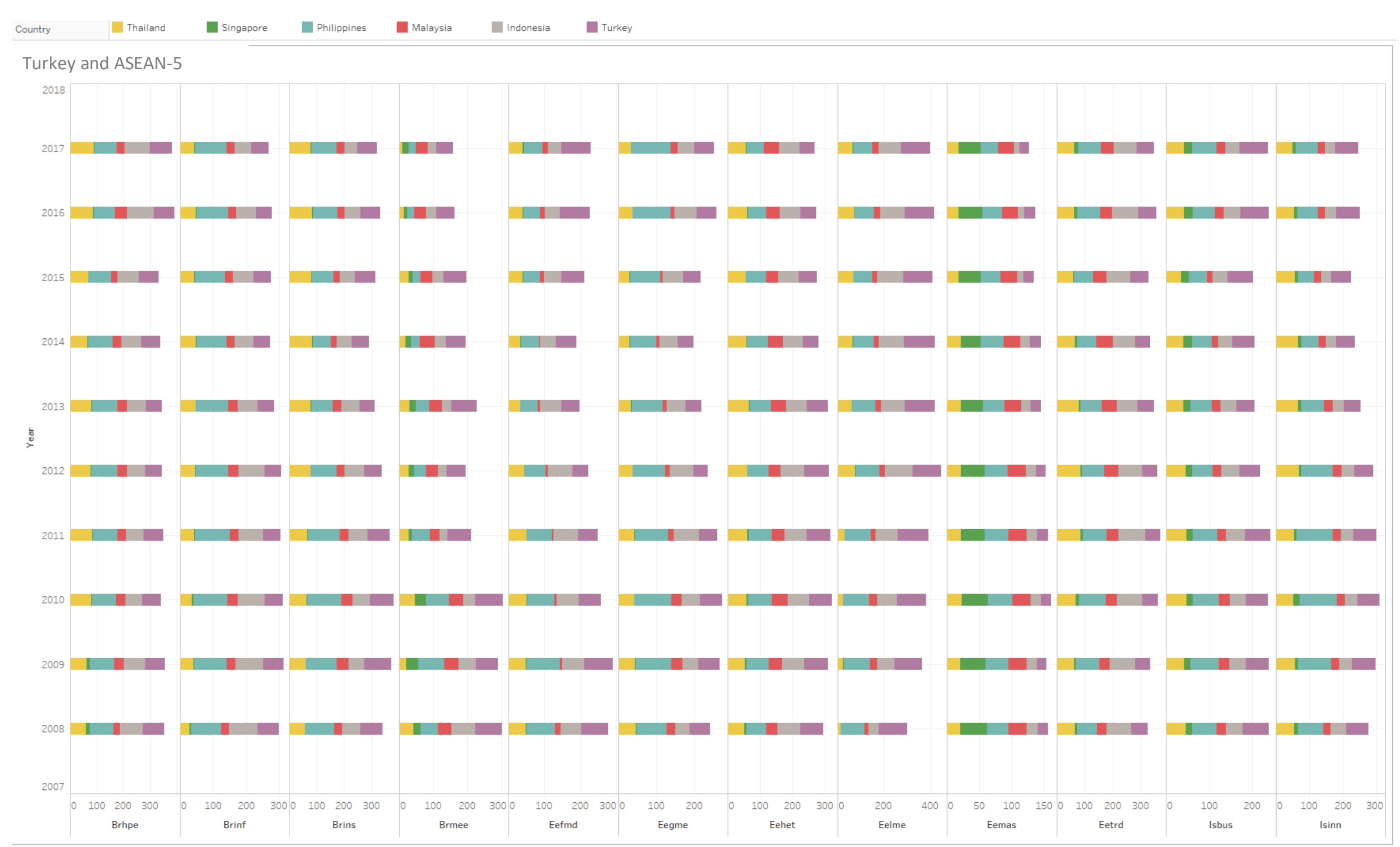

\section{Source: Author}

Figure A2: Turkey and ASEAN-5 


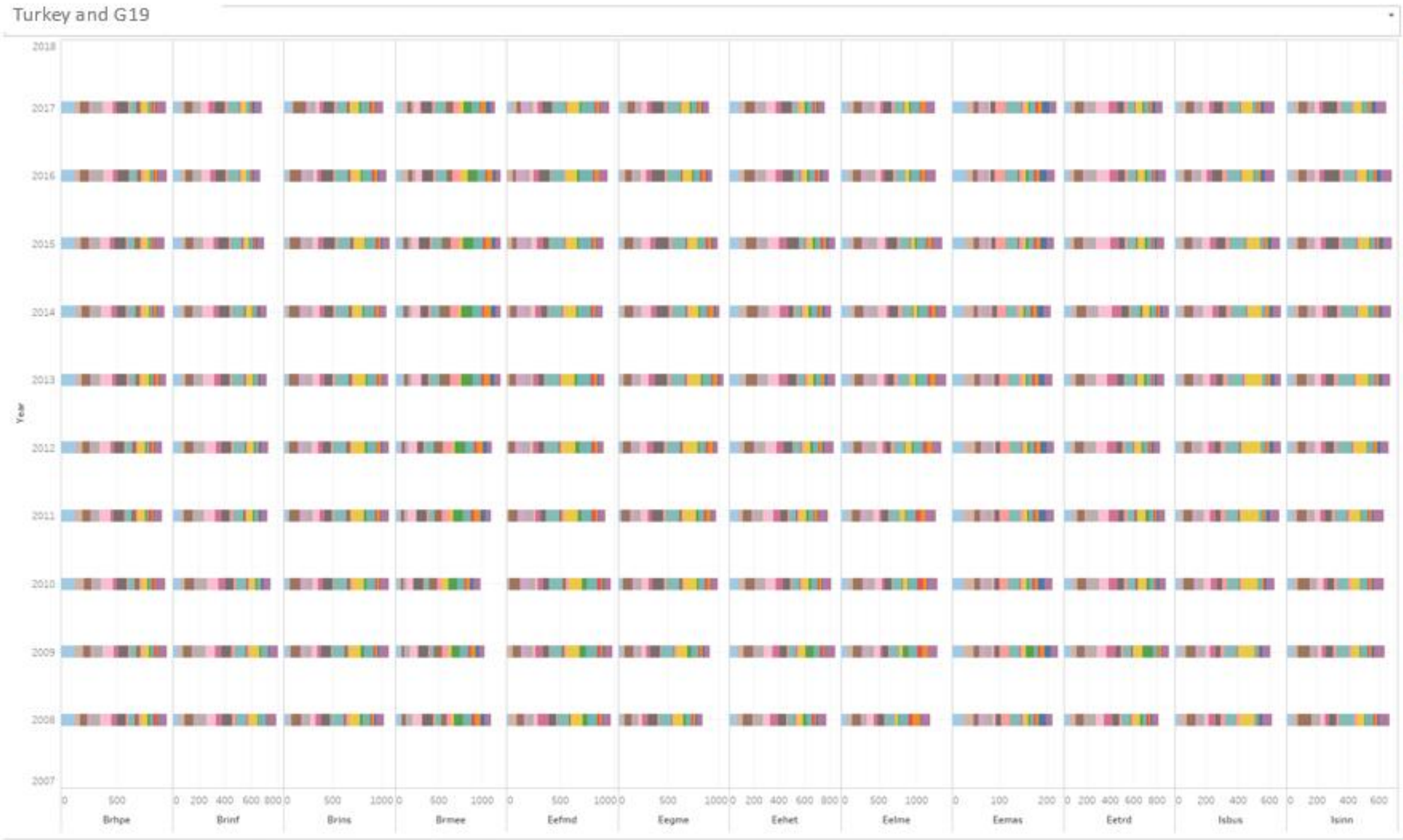

Figure A3: Turkey and G19 